\title{
ENVIRONMENTAL ASSESSMENT OF Remedial Action at the SLICK Rock URANIUM MILL TAILINGS SITES SLICK ROCK, COLORADO
}

January 1995

\section{DISCLAIMER}

This report was prepared as an account of work sponsored by an agency of the United States Government. Neither the United States Government nor any agency thereof, nor any of their employees, makes any warranty, express or implied, or assumes any legal liability or responsibility for the accuracy, completeness, or usefulness of any information, apparatus, product, or process disclosed, or represents that its use would not infringe privately owned rights. Reference herein to any specific commercial product, process, or service by trade name, trademark, manufacturer, or otherwise does not necessarily constitute or imply its endorsement, recommendation, or favoring by the United States Government or any agency thereof. The views and opinions of authors expressed herein do not necessarily state or reflect those of the United States Government or any agency thereof.

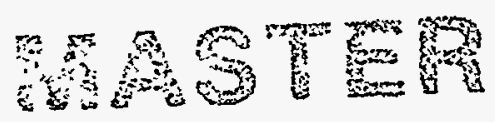

DISTRIBUTION OF THIS DULUMENT IS UNLIMITED

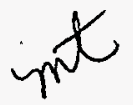




\section{INTENDED FOR PUBLIC RELEASE}

This report has been reproduced from the best available copy. Available in paper copy and microfiche.

Number of pages in this report: 172

DOE and DOE contractors can obtain copies of this report from:

Office of Scientific and Technical Information

P.O. Box 62

Oak Ridge, TN 37831

(615) 576-8401

This report is publicly available from:

National Technical Information Service

Department of Commerce

5285 Port Royal Road

Springfield, VA 22161

(703) 487-4650 


\section{DISCLAIMER}

Portions of this document may be illegible in electronic image products. Images are produced from the best available original document. 


\section{ENVIRONMENTAL ASSESSMENT OF REMEDIAL ACTION AT THE SLICK ROCK URANIUM MILL TAILINGS SITES \\ SLICK ROCK, COLORADO}

January 1995

Prepared for

U.S. Department of Energy

UMTRA Project Office

Albuquerque, New Mexico

Prepared by

Jacobs Engineering Group Inc.

Albuquerque, New Mexico

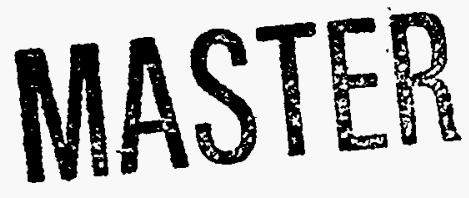

DISTRIBUTION OF: THIS DOCUMENT IS UNLIMITED 


\section{TABLE OF CONTENTS}

Section

Page

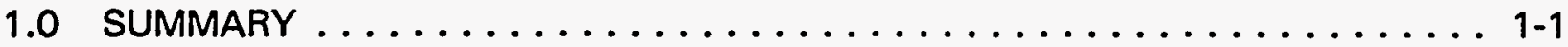

2.0 INTRODUCTION $\ldots \ldots \ldots \ldots \ldots \ldots \ldots \ldots \ldots \ldots \ldots \ldots \ldots \ldots \ldots \ldots \ldots \ldots$

2.1 Description of the processing and disposal sites .............. 2-3

2.1.1 Union Carbide processing site .................. 2-3

2.1.2 North Continent processing site .................. 2-3

2.1.3 Burro Canyon disposal site .................... 2-7

2.1 .4 Borrow sites ......................... . . 2-7

2.2 Alternatives to the proposed action ................. 2-7

2.2 .1 No action $\ldots \ldots \ldots \ldots \ldots \ldots \ldots \ldots \ldots \ldots \ldots \ldots \ldots \ldots . \ldots \ldots$

2.2.2 Alternatives no longer under consideration $\ldots \ldots \ldots \ldots \ldots \ldots$

3.0 DESCRIPTION OF THE PROPOSED ACTION .................. $3-1$

3.1 Borrow sites . . . . . . . . . . . . . . . . . . . 3-6

3.2 Areas under supplemental standard consideration . . . . . . . . . . 3-6

3.3 Compliance with EPA standards . . . . . . . . . . . . . . . 3-7

3.4 Compliance with other requirements $\ldots \ldots \ldots \ldots \ldots \ldots \ldots \ldots \ldots . \ldots \ldots$

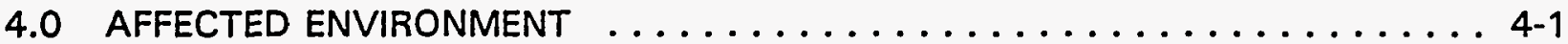

4.1 Radiation characteristics ......................... $4-1$

4.2 Geology ............................... $4-2$

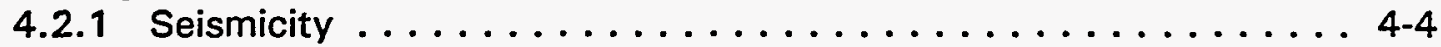

4.2 .2 Soils .......................... $4-4$

4.2 .3 Borrow sites $\ldots \ldots \ldots \ldots \ldots \ldots \ldots \ldots \ldots \ldots \ldots \ldots \ldots$

4.3 Ground water ............................ 4.5

4.3.1 Description of local hydrogeology . . . . . . . . . . . . . 4-5

4.3.2 Ground water quality .................. 4-7

4.3 .3 Ground water use ...................... 4-7

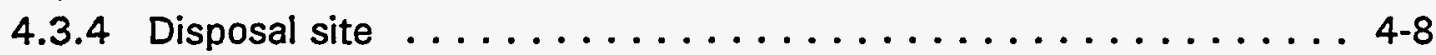

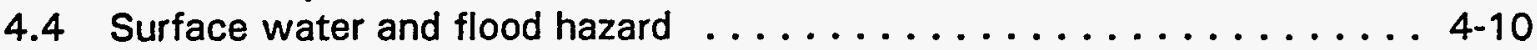

4.4.1 Processing sites ..................... 4-11

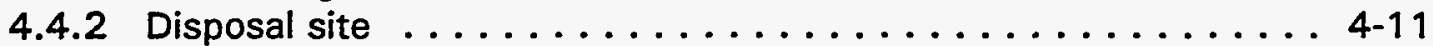

4.4 .3 Borrow sites ......................... 4-12

4.4.4 Surface water uses, classifications, and standards . . . . . . 4-12

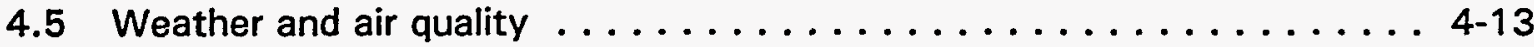

4.6 Flora and fauna ............................. 4.13

4.6.1 Processing sites ....................... 4-13

4.6.2 Disposal site ........................ 4-14

4.6 .3 Borrow sites ......................... 4-15

4.6.4 Threatened and endangered species .............. 4-15

4.6 .5 Wetlands ............................ 4-16

4.7 Historic and cultural resources $\ldots \ldots \ldots \ldots \ldots \ldots \ldots \ldots \ldots \ldots \ldots$

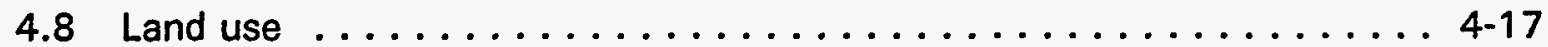

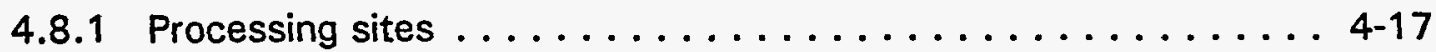

4.8 .2 Disposal site ..................... 4-18 
TABLE OF CONTENTS (Concluded)

Section

Page

4.8.3 Borrow sites ...................... 4-18

4.9 Socioeconomic characteristics .................... 4-19

4.10 Transportation . . . . . . . . . . . . . . . . . . . . 4-20

5.0 ENVIRONMENTAL IMPACTS $\ldots \ldots \ldots \ldots \ldots \ldots \ldots \ldots \ldots \ldots \ldots \ldots$

5.1 Radiation ............................ 5-1

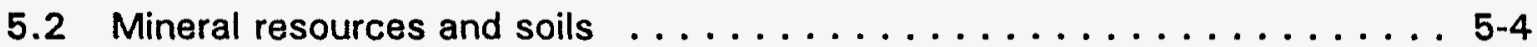

5.3 Ground water ........................... 5-5

5.3 .1 Processing sites . . . . . . . . . . . . . . . 5-5

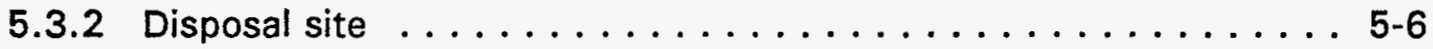

5.4 Surface water . . . . . . . . . . . . . . . . . 5

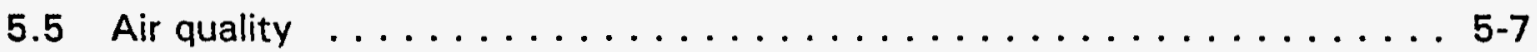

5.6 Flora and fauna . . . . . . . . . . . . . . . . . . 5-8

5.7 Historic and cultural resources . . . . . . . . . . . . . 5-10

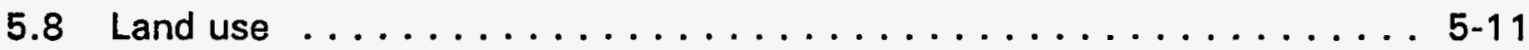

5.8 .1 Processing sites . . . . . . . . . . . . . . . 5-11

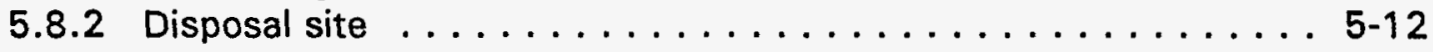

5.8 .3 Borrow sites . . . . . . . . . . . . . . . 5 5-12

5.9 Socioeconomics . . . . . . . . . . . . . . . . 5-13

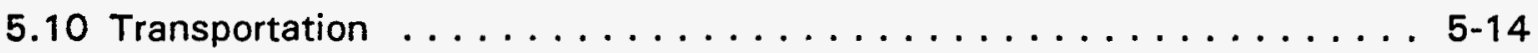

5.11 No action .......................... 5 . . . . . .

5.12 Potential impacts and mitigation measure summary . . . . . . 5-15

6.0 CONSULTATION AND COORDINATION ................. 6 .1

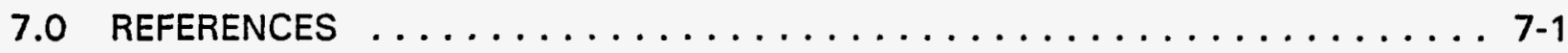

ATTACHMENT 1 BIOLOGICAL ASSESSMENT

ATTACHMENT 2 FLOODPLAIN/WETLANDS ASSESSMENT 


\section{LIST OF FIGURES}

Figure

2.1 Location of the Union Carbide, North Continent, and Burro Canyon sites near Slick Rock, Colorado . . . . . . . . . . . . . . . . . . . . . . 2-2

2.2 Locations of the UMTRA processing, disposal, and borrow sites near Slick Rock, Colorado . . . . . . . . . . . . . . . . . . . . . . . . 2-4

2.3 Location of the UC tailings pile near Slick Rock, Colorado . . . . . . . . . . 2-5

2.4 Location of the NC tailings pile near Slick Rock, Colorado . . . . . . . . . 2-6

3.1 Cross section of the disposal cell at the proposed Burro Canyon disposal site near Slick Rock, Colorado . . . . . . . . . . . . . . . . 3-3

3.2 Disposal cell for the Slick Rock tailings near Slick Rock, Colorado . . . . . . . . . 3-4

3.3 Area under supplemental standards consideration at the Slick Rock tailings sites, Slick Rock, Colorado . . . . . . . . . . . . . . . . . 3-8

3.4 Areal extent of Ra-226 soil concentrations exceeding $5 \mathrm{pCi} / \mathrm{g}$ at the Slick Rock tailings sites, Slick Rock, Colorado . . . . . . . . . . . . . . 3-9

4.1 Physiographic features in the region of the Dolores River drainage basin $\ldots \ldots$. . 4-3

\section{LIST OF TABLES}

Table

2.1 Comparison of alternatives considered in the CADSAR $\ldots \ldots \ldots \ldots$

4.1 Characteristics of the contaminated materials at the Slick Rock, Colorado, UMTRA processing sites . . . . . . . . . . . . . . 4-1

4.2 Processing sites ground water data $\ldots \ldots \ldots \ldots \ldots \ldots \ldots \ldots \ldots$

4.3 Proposed disposal site ground water data . . . . . . . . . . . . . 4-8

5.1 Excess short-term health effects for the general public and remedial action workers ${ }^{a, b}$

5.2 Plant community types potentially disturbed during the remedial action at the Slick Rock UMTRA sites near Slick Rock, Colorado 


\section{LIST OF ACRONYMS AND ABBREVIATIONS}

\section{Acronym}

ac

BLM

CADSAR

CASA

CERCLA

CDPHE

$\mathrm{cm}$

CR

DOE

EA

EPA

FBDU

$\mathrm{ft}$

$\mathrm{ft}^{3} / \mathrm{s}$

FWS

gpd

ha

in

$\mathrm{km}$

L/S

LTSP

$\mu \mathrm{R} / \mathrm{hr}$

$m$

$m^{2}$

$\mathrm{m}^{3}$

$\mathrm{m}^{3} / \mathrm{s}$

$\mathrm{MCL}$

$\mathrm{mg} / \mathrm{L}$

$\mathrm{mi}$

MSL

NC

NEPA

NRC

NRHP

$\mathrm{pCi} / \mathrm{g}$

$\mathrm{pCi} / \mathrm{L}$

$\mathrm{pCi} / \mathrm{m}^{2} \mathrm{~s}$

PMP

POC

Ra-226, Ra-228

RAC

Rn-222

RRM

SH

\section{Definition}

acre

Bureau of Land Management

Comparative Analysis of Disposal Site Alternatives Report

Complete Archaeological Service Associates

Comprehensive Environmental Response, Compensation, and Liability

Act

Colorado Department of Public Health and the Environment

centimeter

county road

U.S. Department of Energy

environmental assessment

U.S. Environmental Protection Agency

Ford, Bacon \& Davis Utah, Inc.

foot

cubic feet per second

Fish and Wildlife Service

gallons per day

hectare

inch

kilometer

liters per second

long-term surveillance plan

microröentgens per hour

meter

square meter

cubic meter

cubic meters per second

maximum concentration limit

milligrams per liter

mile

mean sea level

North Continent

National Environmental Policy Act

Nuclear Regulatory Commission

National Register of Historic Places

picocuries per gram

picocuries per liter

picocuries per square meter per second

probable maximum precipitation

point of compliance

radium- 226 and radium-228

Remedial Action Contractor

radon-222

residual radioactive materials

state highway 


\section{LIST OF ACRONYMS AND ABBREVIATIONS (Concluded)}

\begin{tabular}{|c|c|}
\hline Acronym & Definition \\
\hline SHPO & State Historic Preservation Office \\
\hline TDS & total dissolved solids \\
\hline T\&E & threatened and endangered \\
\hline Th-230 & thorium-230 \\
\hline TSP & total suspended particulates \\
\hline$U-238$ & uranium-238 \\
\hline UC & Union Carbide \\
\hline UMTRA & Uranium Mill Tailings Remedial Action \\
\hline UMTRCA & Uranium Mill Tailings Radiation Control Act \\
\hline USGS & U.S. Geological Survey \\
\hline VP & vicinity property \\
\hline $\begin{array}{l}\text { USACE } \\
y d^{3}\end{array}$ & $\begin{array}{l}\text { U.S. Army Corps of Engineers } \\
\text { cubic yard }\end{array}$ \\
\hline
\end{tabular}




\subsection{SUMMARY}

The Uranium Mill Tailings Radiation Control Act of 1978 (42 USC $\$ 7901$ et seq.), hereafter referred to as the UMTRCA, authorized the U.S. Department of Energy (DOE) to clean up two uranium mill tailings processing sites near Slick Rock, Colorado, in San Miguel County. The purpose of the cleanup is to reduce the potential health effects associated with the radioactive materials remaining on the processing sites and on vicinity properties (VPs) associated with the sites. The U.S. Environmental Protection Agency (EPA) promulgated standards for the UMTRCA that contained measures to control the contaminated materials and to protect the ground water from further degradation. Remedial actions at the Slick Rock sites would be performed in accordance with these standards, with the concurrence of the U.S. Nuclear Regulatory Commission (NRC), the Colorado Department of Public Health and the Environment (CDPHE) and the state of Colorado, and with participation from the public.

Contaminated materials cover an estimated 55 acres (ac) (22 hectares [ha]) of the Union Carbide (UC) processing site and 12 ac (5 ha) of the North Continent (NC) processing site. The processing sites are within 1 mile (mi) (1.6 kilometers [km]) of each other and are adjacent to the Dolores River. The sites contain concrete foundations of mill buildings, tailings piles, and areas contaminated by windblown and waterborne radioactive tailings materials. The total estimated volume of contaminated materials is approximately 618,300 cubic yards $\left(y d^{3}\right)\left(472,800\right.$ cubic meters $\left[\mathrm{m}^{3} \mathrm{l}\right)$. In addition to the contamination in the two processing site areas, four VPs were found to contain contamination. As a result of the tailings being exposed to the environment, contamination associated with the UC and NC sites has leached into shallow ground water. Surface water has not been affected. The closest residence is approximately 0.3 air mi $(0.5 \mathrm{~km})$ from either site.

The proposed action is to remediate the UC and NC sites by removing all contaminated materials within the designated site boundaries or otherwise associated with the sites, and relocating them to, and stabilizing them at, a location approximately 5 road mi $(8 \mathrm{~km})$ northeast of the processing sites on land administered by the U.S. Bureau of Land Management (BLM). Remediation would be performed by the DOE's Uranium Mill Tailings Remedial Action (UMTRA) Project. All solid contaminated materials would be buried under 5 feet (ft) (1.5 meters [m]) of rock and soil materials. The proposed disposal site area is currently used by ranchers for cattle grazing over a 7-month period. The closest residence to the proposed disposal site is 2 air $\mathrm{mi}(3 \mathrm{~km})$. An estimated 44 ac $(18 \mathrm{ha})$ of land would be permanently transferred from the BLM to the DOE and restricted from future use.

The materials would be transported via existing roads. Approximately $1500 \mathrm{ft}(460 \mathrm{~m})$ of County Road (CR)-S8 would be temporarily detoured $400 \mathrm{ft}(120 \mathrm{~m})$ southeast of its current location. An estimated $2 \mathrm{mi}(3 \mathrm{~km})$ of the roads would need to be upgraded. The remainder of the route would use an existing two-lane state highway. Access directly to the processing sites on CR-10R, between the processing sites on CR-S9, and to the disposal site would be restricted from the public during remedial action, which is expected to last 19 months.

Positive impacts associated with the proposed action would include a reduction in potential health effects related to the presence of contaminated materials and increases in local expenditures and employment related to the remedial action. 
Adverse impacts associated with the proposed action would include the temporary and permanent loss of wildlife habitat. Grazing areas will be lost due to soil disturbance and construction of the disposal cell, and permanent withdrawal of 44 ac (18 ha) would occur. No known federally listed wildlife or plant species would be directly affected by project activities. Remedial action may require use of approximately $150 \mathrm{ac}-\mathrm{ft}$ $\left(185,000 \mathrm{~m}^{3}\right)$ of water from the Dolores River that would have a cumulative impact on water use in other parts of the river. Water from the river would be used only when water levels are high enough to ensure that adequate flow remains to support fish and wildife dependent on the river. Local ground water may also be used for construction. This would increase the cumulative extraction of water from the upper Colorado River Basin, which may affect four endangered fish species and their critical habitat. Formal consultation with the Fish and Wildlife Service (FWS) has been initiated to mitigate this impact.

A site with potential cultural resource significance outside the boundaries of the proposed disposal site and one site near the UC site have been identified. Both sites would be avoided during construction. No impacts to cultural resources have been identified from consultation with local native American tribes.

Six unpatented mining claims exist within the proposed permanent withdrawal area. The DOE would compensate valid claim holders affected by remedial action to the extent required by law.

Ground water compliance at the UC and NC processing sites will be evaluated during the UMTRA Ground Water Project and documented as part of a separate National Environmental Policy Act (NEPA) process.

For more information, contact:

\author{
Charles Cormier \\ Acting UMTRA Project Manager \\ U.S. Department of Energy \\ UMTRA Project Office \\ 2155 Louisiana NE, Suite 4000 \\ Albuquerque, New Mexico 87110 \\ 505/845-4628
}




\subsection{INTRODUCTION}

In response to concern over the potential public health hazards related to uranium mill tailings and the contaminated materials left abandoned or otherwise uncontrolled at inactive processing sites throughout the United States, Congress enacted Public Law 95604, the UMTRCA, on November 8, 1978 (42 USC $\$ 7901$ et seq.). In the UMTRCA, Congress acknowledged that potential health hazards are associated with uranium mill tailings and identified a number of processing sites that are in need of remedial actions. The UC and NC processing sites near Slick Rock, Colorado, are two of these sites (Figure 2.1). The DOE, through the UMTRA Project Office, is responsible for ensuring that all proposed remedial actions comply with the UMTRCA.

Title I of the UMTRCA authorized the DOE to perform remedial action at the inactive Slick Rock processing sites (as well as at the 22 other inactive sites identified in the UMTRCA) to reduce the potential public health impacts from the remaining residual radioactive materials (RRM). Title II of the UMTRCA authorized the NRC or agreement state to regulate the operation of active uranium processing sites. An agreement state is a state that regulates the active processing sites within its boundaries in accordance with NRC regulations through a cooperative agreement with the NRC. Following the cessation of processing activities, remedial actions at the active (Title II) processing sites are the responsibilities of the site owners and operators pursuant to remedial action or disposal plans approved by the NRC or agreement states. All remedial actions at the inactive (Title I) and active (Title II) processing sites must be completed in accordance with standards promulgated by the EPA.

UMTRCA defines RRM as uranium mill tailings resulting from the processing of ores for the extraction of uranium. RRM is also other waste at the processing site that relates to the processing.

Uranium mill tailings are the residues of uranium ore processing operations. They consist of finely ground rock, similar to sand. Their principal potential hazard results from their production of radon, a radioactive gas formed by the radioactive decay of the uranium in the tailings. Radon can move through the tailings into the air. Over a long period of time, exposure to radon and its decay products increases the probability that health effects (e.g., cancers) may develop in persons exposed to the tailings. Another risk is that radioactive and other hazardous materials may leach through the underlying soils and rock to contaminate the shallow ground water.

If the tailings and associated contaminated materials are not properly stabilized, natural processes such as wind and water erosion, animal burrowing, or human removal of the materials could spread the contamination and increase the potential for public health hazards. To protect public health, the EPA promulgated the standards for remedial actions under the UMTRCA in 40 CFR Part 192 (1994), Health and Environmental Protection Standards for Uranium and Thorium Mill Tailings.

On September 3, 1985, the U.S. Court of Appeals for the Tenth Circuit remanded the EPA ground water standards portion of 40 CFR Part 192 (40 CFR $\$ 192.20(a)(2)$ and (3)). The EPA subsequently proposed new ground water protection standards that, although not 


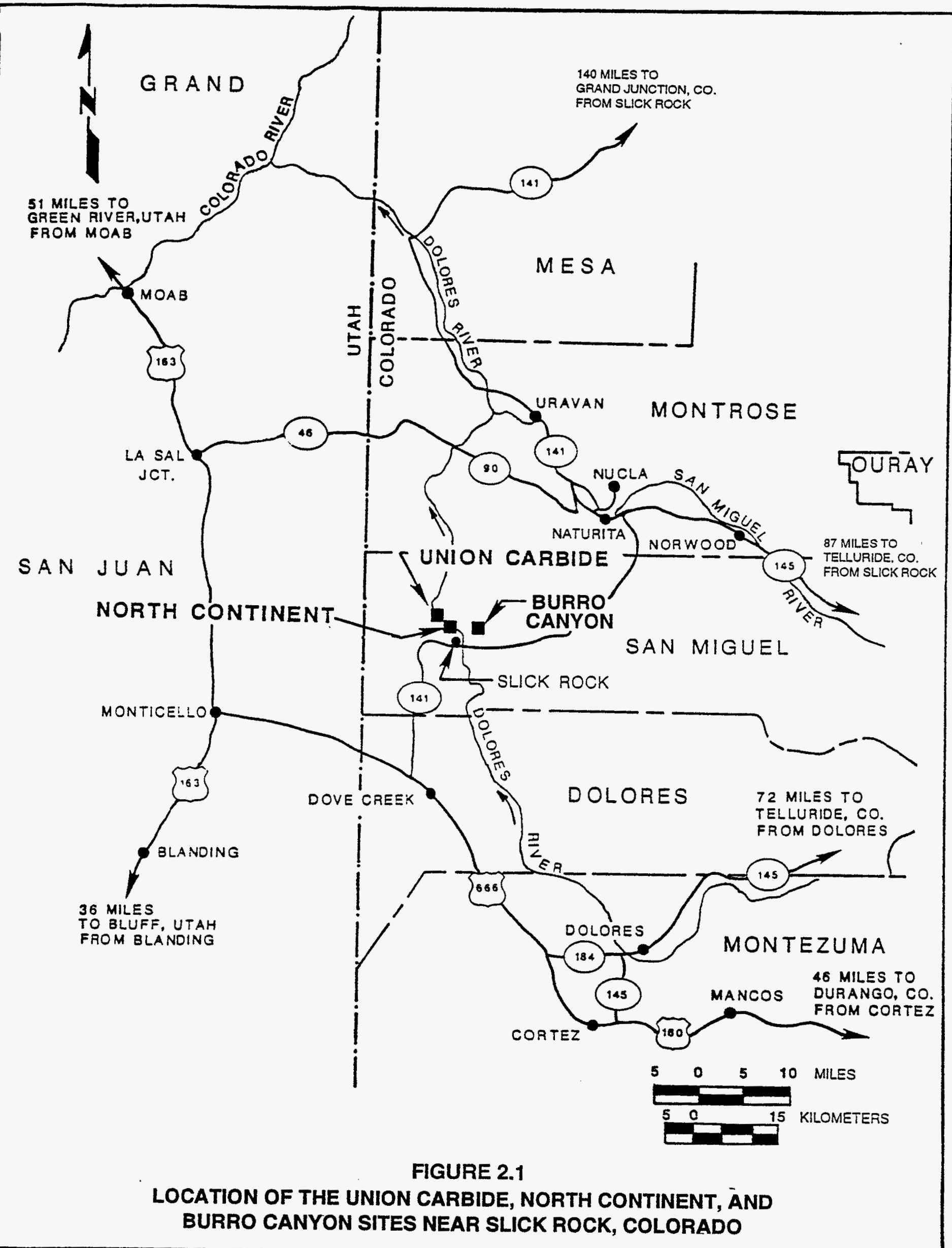


final at the time of this writing, are nonetheless applicable to the remedial action at the UC and NC sites near Slick Rock (52 FR 36000). Compliance with proposed protection standards at the disposal cell is evaluated in this environmental assessment (EA); however, compliance for the residual contaminated ground water at the UC and NC processing sites will be evaluated during the UMTRA Ground Water Project and documented as part of a separate NEPA process.

\subsection{DESCRIPTION OF THE PROCESSING AND DISPOSAL SITES}

\subsubsection{Union Carbide processing site}

The UC processing site is immediately west of the Dolores River and about 2 road mi $(5 \mathrm{~km})$ northwest of the Slick Rock, Colorado, post office (Figure 2.2). Due to the sharp bends in the Dolores River, the distance from the tailings pile to the river ranges from 15 to $150 \mathrm{ft}(4.6$ to $46 \mathrm{~m})$ (Figure 2.3). Contaminated materials at the UC processing site cover an estimated 55 ac ( $22 \mathrm{ha}$ ) with an estimated volume of $533,500 \mathrm{yd}^{3}\left(407,900 \mathrm{~m}^{3}\right)$.

Historical records show evidence of milling activity at the UC site at the turn of the century (MK-Ferguson, 1993). The mill became operational again in September 1957 and ceased operations in December 1961. Ore containing uranium and vanadium was mined in the Slick Rock area and trucked to the mill. The ore was upgraded, then trucked to a UC mill in Rifle, Colorado (Ford, Bacon \& Davis Utah, Inc. [FBDU], 1981). The current site owner is Umetco, a subsidiary of Union Carbide Corporation.

After the mill closed in 1961, the tailings pile was covered with 6 inches (in) (15 centimeters [cm]) of soil obtained from areas adjacent to the pile and vegetated. The pile has vegetation covering 20 percent of the surface (FBDU, 1981). All of the mill buildings have been removed from the processing site, although concrete foundations remain. San Miguel County has constructed a volunteer fire station on the UC site. The former recreational building and dormitory remain off-site. Mobile homes have been removed from a trailer park area off the processing site, near the tailings pile; an off-site gas sweetener plant is currently unoccupied. Windblown contamination from tailings left on the processing site extends downriver and across the mesa from the UC site. Seepage from the UC tailings pile has contaminated the shallow ground water in the alluvium beneath the pile.

\subsubsection{North Continent processing site}

Contaminated materials at the NC site cover approximately 12 ac (5 ha) and have an estimated volume of $84,800 \mathrm{yd}^{3}\left(64,800 \mathrm{~m}^{3}\right)$. The NC site is adjacent to the Dolores River, approximately 1 road mi $(1.6 \mathrm{~km})$ east of the UC site and approximately 1 road mi $(1.6 \mathrm{~km})$ northwest of the Slick Rock, Colorado, post office (Figure 2.4). The original owner of the site, Shattuck Chemical Company, began operations in 1931. North Continent Mines, Inc. acquired the site in 1934. Title was subsequently passed through several other companies, and 


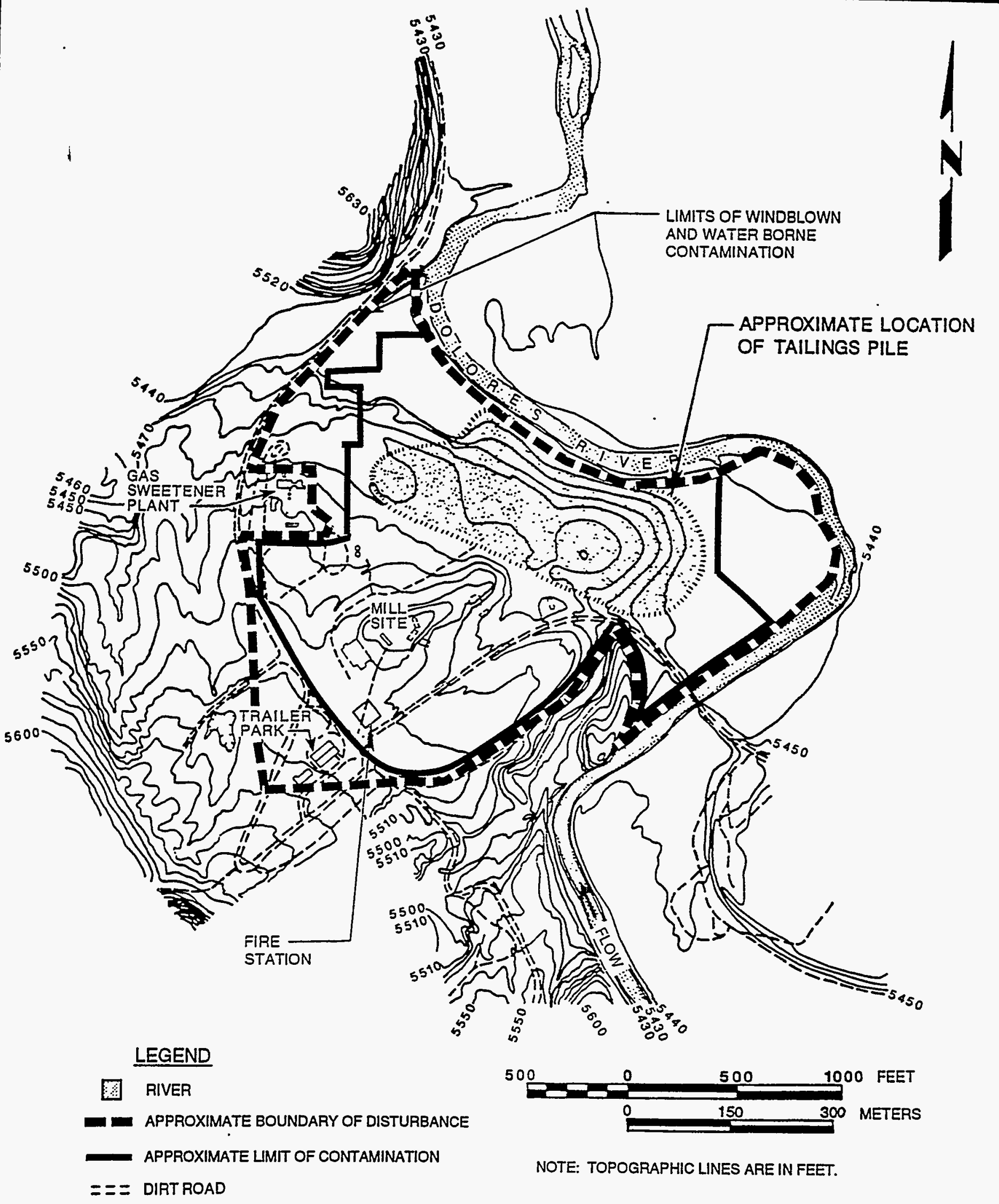

FIGURE 2.3

LOCATION OF THE UC TAILINGS PILE NEAR SLICK ROCK, COLORADO 


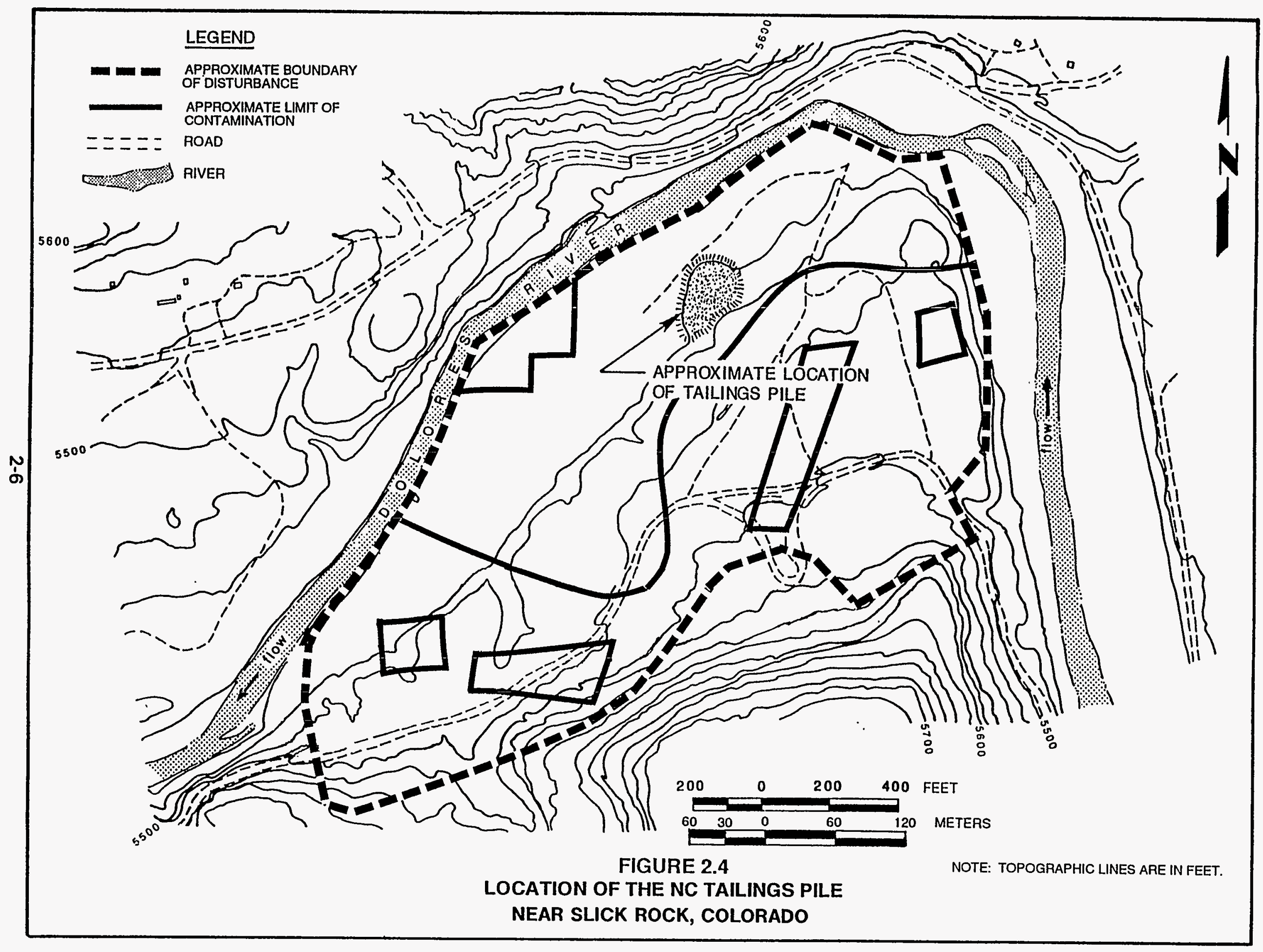


eventually to Umetco, the current owner, in 1957. The NC site also received uranium- and vanadium-bearing ore that was mined near Slick Rock.

After milling operations were discontinued in the early 1960s, the pile was covered with 6 in $(15 \mathrm{~cm})$ of soil and vegetation. Seepage from the NC tailings pile has contaminated the shallow ground water in the alluvium beneath the site. There are no structures on the NC site.

\subsubsection{Burro Canyon disposal site}

The proposed Burro Canyon disposal site is located above the 1000-year floodplain of the Dolores River on BLM-administered land approximately $5 \mathrm{mi}$ ( 8 $\mathrm{km}$ ) east of the NC site. The area is used by ranchers for grazing cattle about 7 months of the year. The surrounding area is BLM-administered public land and is used primarily for grazing, hunting, and other recreational uses, with occasional mineral development as market conditions warrant. Approximately $44 \mathrm{ac}$ (18 ha) would be removed from future use.

\subsubsection{Borrow sites}

Two borrow sites have been identified that may be used as a source of materials for the radon barrier and the erosion protection layer of the disposal cell. The Disappointment Valley borrow site is approximately 4.4 road mi $(7.1 \mathrm{~km})$ from the disposal site on relatively flat terrain in the desert-shrub habitat. The borrow site would be used as a source of sand, clay, and silt for the radon barrier. The borrow site area consists of approximately 65 ac (26 ha) of land administered by the BLM. The land immediately west of the borrow site is privately owned; land on all other sides of the site is administered by the BLM.

The Dolores River borrow site is on private land on a terrace above the Dolores River. The site would be used as a source of gravel and cobbles for the erosion control layer. The borrow area covers approximately 25 ac (10 ha), in a 60-ac (24-ha) area of cleared and irrigated land adjacent to the Dolores River between the UC and NC sites. The area is used for pasture and growing hay.

\subsection{ALTERNATIVES TO THE PROPOSED ACTION}

The proposed Burro Canyon disposal site was selected based on the results of a twenty-five criteria alternate disposal site selection process agreed upon by the state of Colorado, DOE, and NRC (DOE, 1986a). This section describes the no action alternative as well as alternatives no longer under consideration.

\subsubsection{No action}

The no action alternative consists of taking no steps toward the remediation of the processing sites. No public lands would be disturbed. The contaminated materials and debris would remain in place. This alternative would not be 
consistent with the intent of Congress in the UMTRCA and would not result in compliance with EPA standards.

\subsubsection{Alternatives no longer under consideration}

The DOE's analysis of disposal site alternatives encompassed technical, environmental, and cost factors, as well as the risks associated with each alternative. Technical factors included disposal site stability and ground water conditions; environmental factors included the presence of threatened and endangered species and the proximity of residents and population centers. Cost factors took into account special design features (e.g., costs of special erosion protection measures) and haulage distances for both contaminated materials and borrow materials. Risks were evaluated for each alternative by probability and included disposal site stability, erosion potential, and ground water conditions. Public safety issues related to the transportation of mill tailings over state highways were also considered in the disposal site selection process. The state of Colorado and the NRC were consulted during these analyses, and the results are provided in the Comparative Analysis of Disposal Site Alternatives Report (CADSAR) for the Slick Rock processing sites (DOE, 1986b).

The CADSAR considered three alternatives in detail: stabilizing the tailings in place; stabilizing the tailings on-site; and relocating the tailings to one of several other sites. Table 2.1 provides a description of the alternatives, the 1986 estimated cost, the impacts, and the reason each alternative was not analyzed further.

In 1989, the haul distances, site and design adequacy, and costs for the relocation of tailings to Burro Canyon and to the Naturita Dry Flats site were evaluated (Hill, 1989). The relocation to Burro Canyon site option was estimated to be $\$ 5.7$ million, and the relocation to the Naturita Dry Flats estimate was $\$ 11$ million. The cost of relocation to Naturita was re-evaluated in 1994. It was reconfirmed that this option would not be cost effective (Banani, 1994).

In 1990, additional alternate disposal site selection research was done that considered the Burro Canyon area, Horse Range Mesa, Spud Patch near Egnar, and the utilization of mined lands (McBee, 1990). In 1993, the cost to relocate the tailings to the La Sal, Utah, Title II uranium mill tailings site was estimated to be $\$ 37$ million (Selby, 1993).

In 1994, relocation of the Slick Rock tailings to Umetco's Uravan Project site, 13 miles northwest of Naturita, Colorado, was considered. While the Uravan site is currently permitted for the disposal of the UMTRA Project Naturita RRM by CDPHE, the site is not permitted to accept the Slick Rock materials, nor is there presently enough space in that part of the facility to accommodate both volumes of RRM. Other disposal areas currently in operation at Uravan contain Comprehensive Environmental Response, Compensation, and Liability Act (CERCLA) wastes that would present a CERCLA liability risk. This would require the development and permitting of a new disposal area to accommodate the 


\begin{tabular}{|c|c|c|c|}
\hline & Stabilization in place & Stabilization on-site & Relocate to another site \\
\hline Description & $\begin{array}{l}\text { Tailings at each of the processing } \\
\text { sites would be covered with large } \\
\text { rock to armor the pile against the } \\
\text { probable maximum flood. All } \\
\text { disturbed areas would be } \\
\text { restored, recontoured, and } \\
\text { revegetated to provide drainage. } \\
\text { No transportation of the tailings } \\
\text { would occur; however, } \\
\text { construction workers and } \\
\text { materials would have to be } \\
\text { transported to the processing } \\
\text { sites. }\end{array}$ & $\begin{array}{l}\text { Tailings from the UC and NC sites } \\
\text { would be consolidated at the UC site } \\
\text { out of the Dolores River floodplain on } \\
\text { the escarpment, which is a bedrock } \\
\text { surface capped by alluvial rock. A } \\
\text { radon barrier of compacted soil } \\
\text { would be placed over the pile to } \\
\text { inhibit infiltration of water to the } \\
\text { tailings and the emanation of radon } \\
\text { gas. No liner would be required to } \\
\text { protect ground water. All excavated } \\
\text { and disturbed areas would be } \\
\text { restored, recontoured, and } \\
\text { revegetated to provide drainage }\end{array}$ & $\begin{array}{l}\text { Tailings from the UC and NC sites } \\
\text { would be excavated and } \\
\text { transported to a disposal cell that } \\
\text { would be constructed } \\
\text { approximately } 6 \mathrm{mi}(10 \mathrm{~km}) \text { from } \\
\text { the processing sites. All } \\
\text { excavated and disturbed areas } \\
\text { would be restored, recontoured, } \\
\text { and revegetated. } \\
\text { This alternative is very similar to } \\
\text { the proposed action in this EA } \\
\text { except for the specific location of } \\
\text { the disposal site. }\end{array}$ \\
\hline $\begin{array}{l}\text { Estimated } \\
\text { cost in } 1986\end{array}$ & $\$ 9,643,000$ & $\$ 6,032,000$ & $\$ 9,213,000$ \\
\hline Impacts & $\begin{array}{l}\text { The impacts to the processing } \\
\text { sites described in this EA for the } \\
\text { proposed action would apply to } \\
\text { the stabilization-in-place } \\
\text { alternative. Additional impacts } \\
\text { could occur with this alternative } \\
\text { in the event a flood would break } \\
\text { through the disposal cell and } \\
\text { wash the tailings downstream. } \\
\text { However, these additional } \\
\text { impacts were not analyzed } \\
\text { further. }\end{array}$ & $\begin{array}{l}\text { The impacts to the processing sites } \\
\text { described in this EA for the proposed } \\
\text { action would apply to the } \\
\text { stabilization-on-site alternative. } \\
\text { Additional impacts could occur with } \\
\text { this alternative in the event a flood } \\
\text { would break through the disposal cell } \\
\text { and wash the tailings downstream. } \\
\text { However, additional impacts were } \\
\text { not analyzed further. }\end{array}$ & $\begin{array}{l}\text { The impacts to the processing } \\
\text { sites and disposal site described } \\
\text { in this EA for the proposed action } \\
\text { would apply to this alternative. }\end{array}$ \\
\hline $\begin{array}{l}\text { Reason for } \\
\text { elimination }\end{array}$ & $\begin{array}{l}\text { NRC regulations for disposal cell } \\
\text { construction do not allow } \\
\text { disposal cells to be built in } \\
\text { floodplains. }\end{array}$ & $\begin{array}{l}\text { A ground water protection strategy } \\
\text { could not developed due to complex } \\
\text { subsurface topography and site } \\
\text { conditions. }\end{array}$ & $\begin{array}{l}\text { Disposal at alternate locations } \\
\text { was eliminated due to proximity } \\
\text { to ground water. }\end{array}$ \\
\hline
\end{tabular}


Slick Rock RRM. In addition, the permit for the Naturita materials is being contested by Colorado environmental groups, which could affect the viability of the approval of a permit for the additional Slick Rock RRM. Other concerns include the lengthier 55-mile haul to the Uravan site; the increased environmental, health, and safety risks related to the longer haul; and the greater disposal costs. The cost of relocation to Uravan was estimated at $\$ 28$ million, versus the estimated $\$ 7.5$ million cost of disposal at the proposed Burro Canyon site.

The proposed Burro Canyon site was presented in 1990 after other previously considered alternatives were eliminated for engineering, geotechnical, geological, environmental, and ground water hydrological considerations. After detailed study, the proposed Burro Canyon site was carried forward for further analysis as the DOE's proposed disposal site and was concurred upon by the state of Colorado and the NRC. 


\subsection{DESCRIPTION OF THE PROPOSED ACTION}

The proposed action is to remove, relocate, and consolidate tailings-contaminated materials associated with the UC and NC sites in a disposal cell at Burro Canyon (see Figure 2.1). This would affect approximately $125 \mathrm{ac}$ (51 ha) of surface area at the UC and NC sites. The disposal cell would be excavated and prepared for the emplacement of contaminated materials. The UC and NC sites would be excavated to remove contaminated materials, and the materials would be transported by truck to the disposal cell. The disposal cell would be covered with a natural material, multicomponent cover. Maintenance of the cover will be detailed in the long-term surveillance plan (LTSP).

Remedial action activities would require at least one temporary staging area for construction operations. The staging area would hold several trailers for offices, a fuel farm, and a parking area for employee vehicles and heavy earth-moving equipment. The location of the staging area would be determined by the Remedial Action Contractor (RAC) and its subcontractors prior to remedial action. The staging area would be within the area scoped and cleared for this EA.

The disposal cell would hold approximately $618,300 \mathrm{yd}^{3}\left(472,800 \mathrm{~m}^{3}\right)$ of contaminated material and cover an area approximately $610 \mathrm{ft}(186 \mathrm{~m})$ wide and $905 \mathrm{ft}(276 \mathrm{~m})$ long along the southwest face of the mesa. The cell would include a radon barrier and an erosion protection layer. The height of the cell would range from $30 \mathrm{ft}(9 \mathrm{~m})$ to $50 \mathrm{ft}$ $(15 \mathrm{~m})$ above the existing ground surface. The base of the cell would be excavated and compacted to prepare for placement of the contaminated materials. The remaining excavated material would be left on the disposal site, graded, and reseeded.

A temporary withdrawal of 400 ac (162 ha) was requested and received from the BLM in 1993. The proposed action would disturb $178 \mathrm{ac}(72 \mathrm{ha})$ of this withdrawal area. The purpose of the temporary withdrawal is to protect and segregate the land until requirements for the permanent transfer of $44 \mathrm{ac}$ (18 ha) of administrative jurisdiction from the BLM to the DOE, under the authority of the UMTRCA, are complete.

Effective on the date of publication of a legal description of the Burro Canyon site by the BLM in the Federal Register, these lands were segregated from all forms of appropriation under public land laws, including mining laws. However, the land remains open to mineral leasing and development, subject to concurrence by the DOE, NRC, and the Department of the Interior. The DOE must also submit applications for any applicable or required permits, including, but not limited to, the rights-of-way reservation, free use, and Section 404 permits. The right-of-way application was submitted by DOE to BLM on June 6, 1994 . No site activity would take place until site jurisdiction transfer from BLM to DOE had taken place. A Plan of Development would be formulated subsequent to the approval of the right-of-way reservation. The Plan of Development would include centerline surveys, use of right-of-way, impacts associated with construction of the right-of-way, work force information, and commuting information.

Approximately $618,300 \mathrm{yd}^{3}\left(472,800 \mathrm{~m}^{3}\right)$ of contaminated materials from the NC and UC sites would be removed from the land surface and excavated to a depth protective of the environment. Approximately 92 ac ( $37 \mathrm{ha})$ of soils at the UC site and 33 ac (13 ha) at the 
NC site will be disturbed during remedial action. In addition to contaminated soils, contaminated materials from the NC and UC sites placed in the disposal cell would include concrete, building materials (including wood), and steel scrap.

Existing haul roads would be used to move tailings from the processing sites to the disposal site. A BLM transportation and utility right-of-way application reservation was submitted in June 1994 and included upgrades to the haul roads. State Highway (SH) 141 between the NC and proposed Burro Canyon sites may be upgraded by applying new pavement coating, installing temporary traffic signs, and improving line-of-sight at the Burro Canyon turn-off. New signs and as-needed upgrades would also be constructed for the county roads. CR-T11 to the disposal site would be extended to approximately $4200 \mathrm{ft}(1280 \mathrm{~m})$ and widened to approximately $40 \mathrm{ft}(12 \mathrm{~m})$. The right-of-way would be widened to $100 \mathrm{ft}(30 \mathrm{~m})$. CR-10R would be widened to approximately $32 \mathrm{ft}(10 \mathrm{~m})$. Surface improvements to county roads would be made with gravel and dirt. Approximately $1500 \mathrm{ft}(457 \mathrm{~m})$ of CR-S8 within the UC site would be temporarily detoured along an old alignment. During the hauling period, Colorado-certified flag persons would regulate the vehicular traffic during truck transport hours. Direct access to the processing sites on CR-10R, between the processing sites on CR-S9, and the disposal site access road that turns north from CR-T11 to the disposal site, would be restricted from public use.

The RAC also will secure a San Miguel County Special Use permit to comply with the requirements for hauling on county roads.

All roads would be returned to their pre-construction conditions and alignments after remedial action was complete. It is estimated that a maximum of 280 highway truck trips would take place per day between the processing sites and the disposal cell during the months of the first construction season. The second construction season would involve the hauling of borrow materials. Estimated trips would be dependent upon materials needed and the final selection of borrow sites.

Tailings from the NC site would be moved approximately $4 \mathrm{mi}(6.4 \mathrm{~km})$ to the Burro Canyon site, south on CR-10R, east on SH-141, and north onto CR-T11 to the disposal site. Tailings from the UC site would be moved approximately $5 \mathrm{mi}(8 \mathrm{~km})$ to the Burro Canyon site, east on CR-S8, east on SH-141, and north on CR-T11 to the disposal site. Materials from the NC site would be placed in the disposal cell first, followed by placement of materials from the UC site.

The cell cover would be constructed of approximately $5.5 \mathrm{ft}(1.7 \mathrm{~m})$ of earthen materials. All contaminated materials would be covered with a $2-\mathrm{ft}(0.6-\mathrm{m})$ layer of fine-grained material that would constitute a radon barrier to prevent release of radon into the atmosphere (Figure 3.1). A 2-ft $(0.6-\mathrm{m})$ frost protection layer of fine-grained material would be placed over the radon barrier, after which a 6 -in $(15-\mathrm{cm})$ sand and gravel bedding layer would be added. The top of the cover would consist of 8 in $(20 \mathrm{~cm})$ of riprap from local sources, which would blend with the local environment. The disposal cell would have a 2 to 4 percent topslope and 25 percent sideslopes (Figure 3.2).

The completed disposal cell would occupy an area of 12 ac (5 ha). A buffer area of 32 ac (13 ha) would bring the total removed from future uses to 44 ac (18 ha). The DOE would 


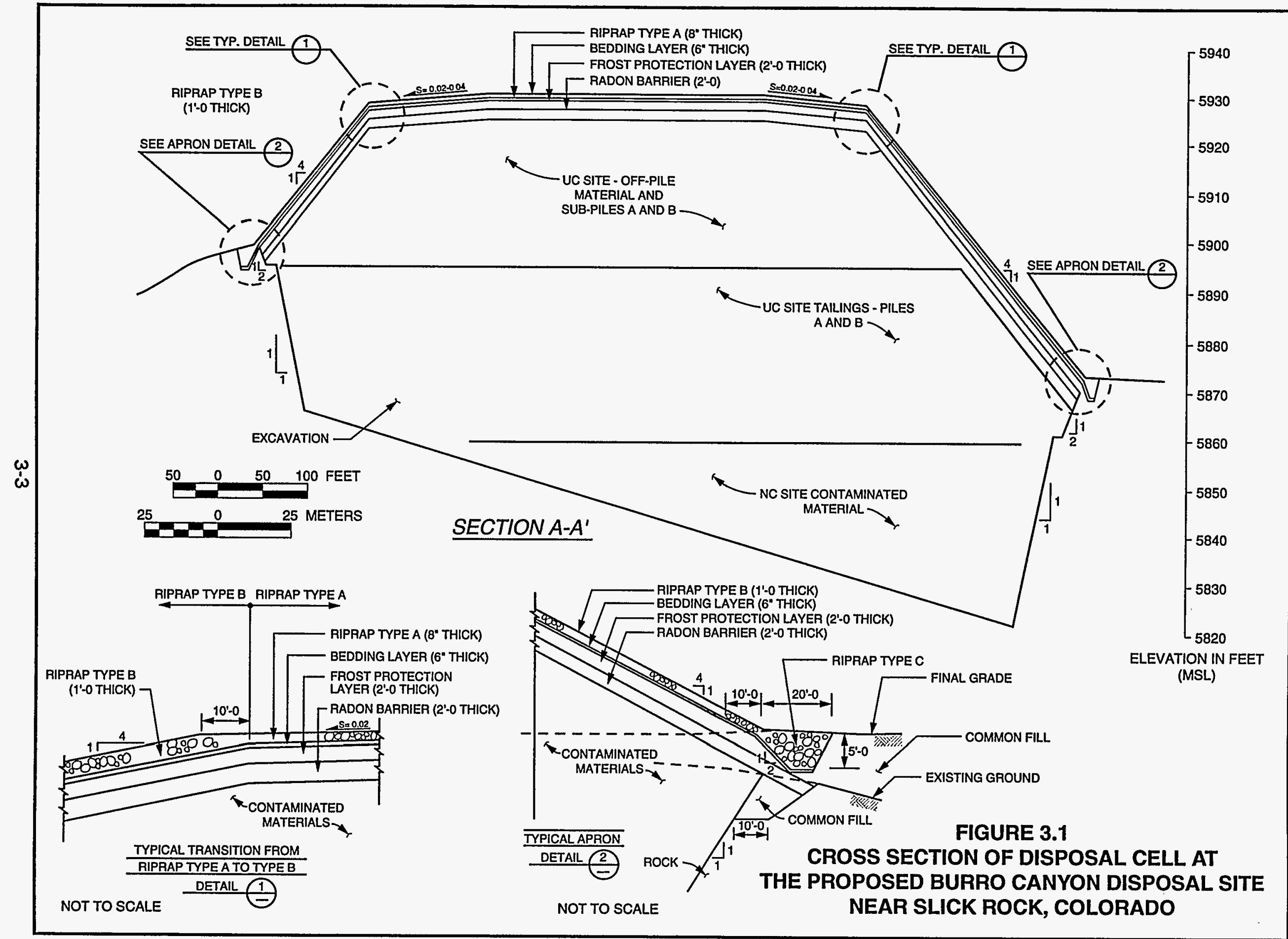




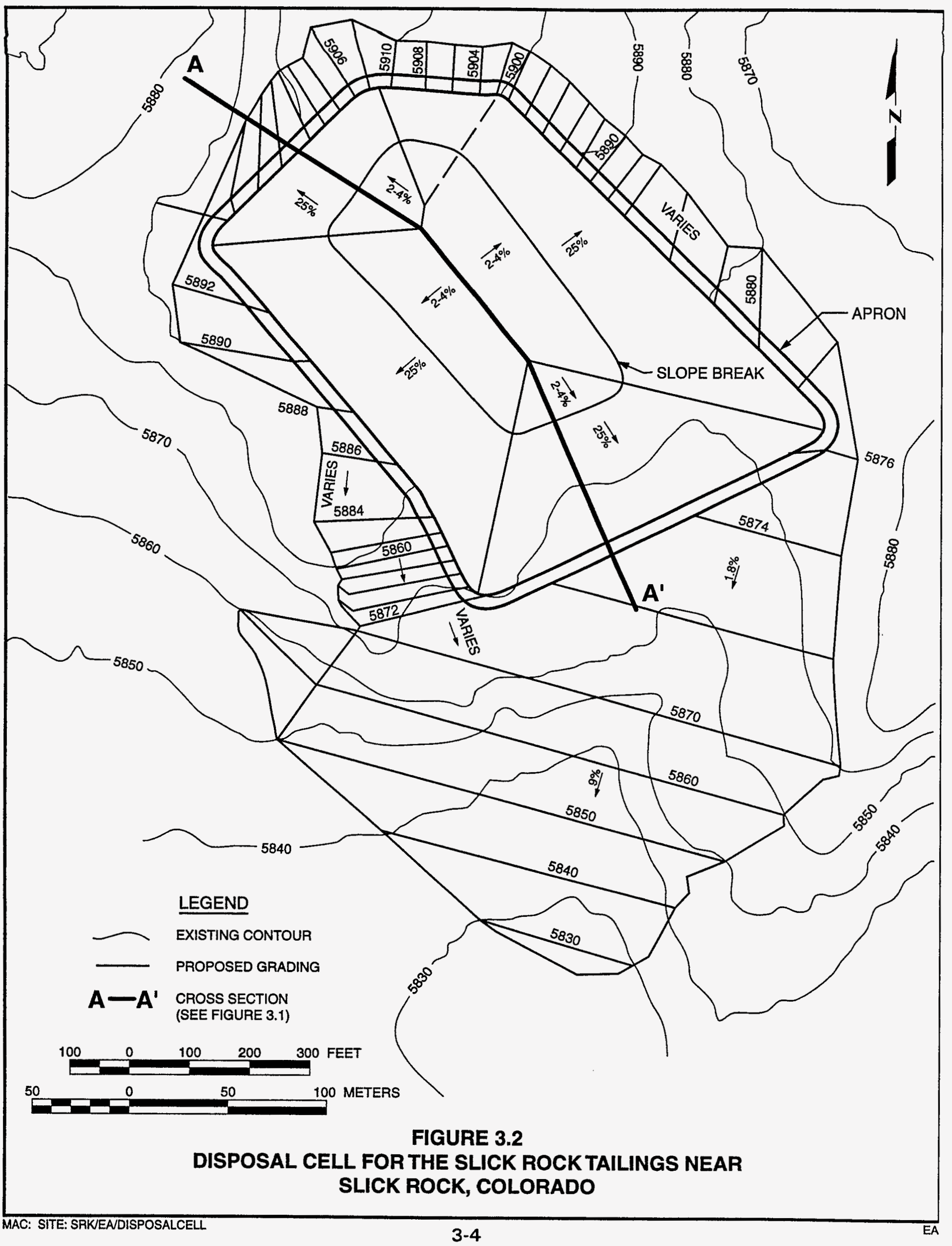


be responsible for long-term surveillance and monitoring of the disposal site. A detailed description of the engineering design is provided in the remedial action plan.

Approximately 150 acre-feet (ac-ft) $\left(185,000 \mathrm{~m}^{3}\right)$ of water would be needed for the remedial action for decontamination and dust suppression. Potential water sources include the Dolores River and local ground water. Water from the river would be used only when water levels are high enough to ensure that adequate flow remained to support fish and wildlife dependent on the river.

Disturbed areas at the UC, NC, proposed Burro Canyon sites, and the borrow areas would undergo restoration after the completion of remedial activities. Excavated areas would be backfilled to match adjacent grade. All graded, excavated, or similarly disturbed soil surfaces would be reseeded in accordance with landowners' and land administrator's requirements.

Remedial action is expected to take 19 months. The summer of the first year would include site preparation, upgrading of the existing dirt road, disposal cell excavation, demolition of existing foundations, and excavation and placement of contaminated materials from the UC and NC sites. A 5-month winter shutdown would be scheduled from approximately mid-November to mid-April. A temporary winter cover may be placed over the contaminated materials. The second-summer activities would include collection of cover materials from the proposed Dolores River and Disappointment Valley borrow sites and construction of the cover system. Final site grading and site restoration would also be performed.

During the haul phase, the work would be performed on an average of 8 hours per day, 5 days per week. The construction season is estimated to be 7 months for each of 2 years. The actual length of the construction season would depend on the weather. The average number of workers for the remedial action would be approximately 100 , with a maximum of up to 160 .

Background levels of total suspended particulates (TSP), radionuclides, and noise would be recorded before implementing the proposed action. Monitoring programs to ensure compliance with applicable standards and regulations would be developed and carried out by the RAC. All necessary local permits would also be secured by the RAC.

The proposed action includes the incorporation of contaminated materials recovered from the four VPs associated with the UC or NC sites. VPS are properties located outside a designated UMTRA Project site boundary that have been contaminated by tailings naturally dispersed by wind or water or removed by people before the potential hazards of the tailings were known. Inclusion of the VP into the UMTRA Project means the land would be remediated to meet the standards of 40 CFR Part 192. Remediation would be preceded by additional characterization, resource clearances, and agreement by DOE, BLM, and the state of Colorado upon remediation plans via the Remedial Action Agreement. Remediation would be contingent upon available funding and the owner's permission.

An LTSP would be developed after processing site remedial action was complete. This document would include descriptions of all maintenance of the disposal site. The LTSP 
would also describe the posting of warnings around the disposal site, periodic site inspections, and provisions for corrective actions.

\subsection{BORROW SITES}

Construction of the proposed disposal cell at Burro Canyon would require gravel, clay, and rock materials for the protective cover. The preferred source of radon barrier and frost protection materials would be the material excavated at the disposal cell site. If the excavated material is unsuitable, the proposed Disappointment Valley borrow site would be the source of earthen materials for the radon barrier (see Figure 2.2). This source is approximately 4.4 road mi $(7.1 \mathrm{~km})$ from the disposal site. Erosion protection materials would be excavated from the Dolores River borrow site (see Figure 2.2) located on a terrace above the Dolores River and between the UC and NC sites. In addition, larger diameter rock may be obtained from deposits adjacent to the UC site.

A total of $68,200 \mathrm{yd}^{3}\left(52,100 \mathrm{~m}^{3}\right)$ of soil covering approximately 65 ac (26 ha) would be excavated from the Disappointment Valley borrow site for radon/ infiltration barrier material. Approximately 25 ac (10 ha) would be disturbed at the Dolores River borrow site to obtain $72,700 \mathrm{yd}^{3}\left(55,600 \mathrm{~m}^{3}\right)$ of rock and gravel.

Before excavating and collecting borrow materials from the Disappointment Valley site, the DOE would apply for a free use permit from the BLM. The free use permit would include the planned volume of materials, size of disturbance, access to the borrow site, and reclamation standards, including stripping and reserving topsoil and restoration plans. The permit application would include clearances for cultural resources and threatened and endangered species.

The remedial action subcontractor would negotiate with the private landowner to purchase borrow materials before excavating from the proposed Dolores River borrow site.

\subsection{AREAS UNDER SUPPLEMENTAL STANDARD CONSIDERATION}

Under certain specific conditions, the DOE may apply supplemental standards to contaminated areas in lieu of meeting the numerical cleanup standards (52 FR 36000). Supplemental standards may be applied if certain conditions are met, including:

- Remedial actions would pose a significant risk to workers or members of the public.

- Remedial actions would directly produce environmental harm that is clearly excessive compared to the health benefits of remediation to persons living on or near the sites, now or in the future. 
- The estimated cost of remedial action is unreasonably high relative to the long-term benefits, and the RRM do not pose a clear present or future hazard.

One such area is a VP located within the Dolores River floodplain across from the UC mill site (Figure 3.3). This area covers 17 ac (7 ha) on a floodplain across the river from the UC tailings site. It is bounded by a $200-\mathrm{ft}$ $(60-\mathrm{m})$ sandstone cliff to the east and the Dolores River to the west. There is no pedestrian access to the site. Based on 19 samples from this area, the radium ( $R a)-226$ concentration ranged from 1 to 25 picocuries per gram $(\mathrm{pCi} / \mathrm{g})$, with an average and standard error of $7.4 \pm 1.4 \mathrm{pCi} / \mathrm{g}$, respectively. The mean Ra-226 concentration is statistically indistinguishable from the cleanup standard of $6.4 \mathrm{pCi} / \mathrm{g}$.

The ratio of Ra-226 to uranium-238 (U-238) in 11 soil samples collected from this area was determined to be $4.2 \pm 0.6$. This indicates the presence of mill tailings that have been deposited from the UC and NC piles by water or wind.

Despite the presence of uranium mill tailings in this area, supplemental standards could be applied to meet the requirements for supplemental standards for the following reasons:

- The average Ra-226 concentration of $7.4 \mathrm{pCi} / \mathrm{g}$ is close to the cleanup standard of $6.4 \mathrm{pCi} / \mathrm{g} / 5 \mathrm{pCi} / \mathrm{g}$ above the background Ra-226 concentration of $1.4 \mathrm{pCi} / \mathrm{g}$ ) (Figure 3.41 .

- Remedial action would result in the destruction of the riparian habitat in the area.

- There is no vehicular or foot access to the site. Remedial action would therefore be very costly because it would be necessary to construct a temporary bridge across the Dolores River.

- Exposures to river users who pass by or enter the floodplain are considered insignificant.

- There is a low probability of health effects due to the Ra-226 concentration anticipated from radon emission, particulate inhalation, or ingestion of contaminated materials.

\subsection{COMPLIANCE WITH EPA STANDARDS}

The purpose of the proposed remedial action is to stabilize contaminated materials associated with the processing sites in a manner that complies with the EPA standards in 40 CFR Part 192. Consistent with this purpose and the EPA standards, the following proposed action design objectives provide for control of radon emissions, long-term stability, and ground water protection.

- Levels of Ra-226 would be reduced to levels consistent with the EPA standards in areas released for unrestricted use (the UC and NC processing 


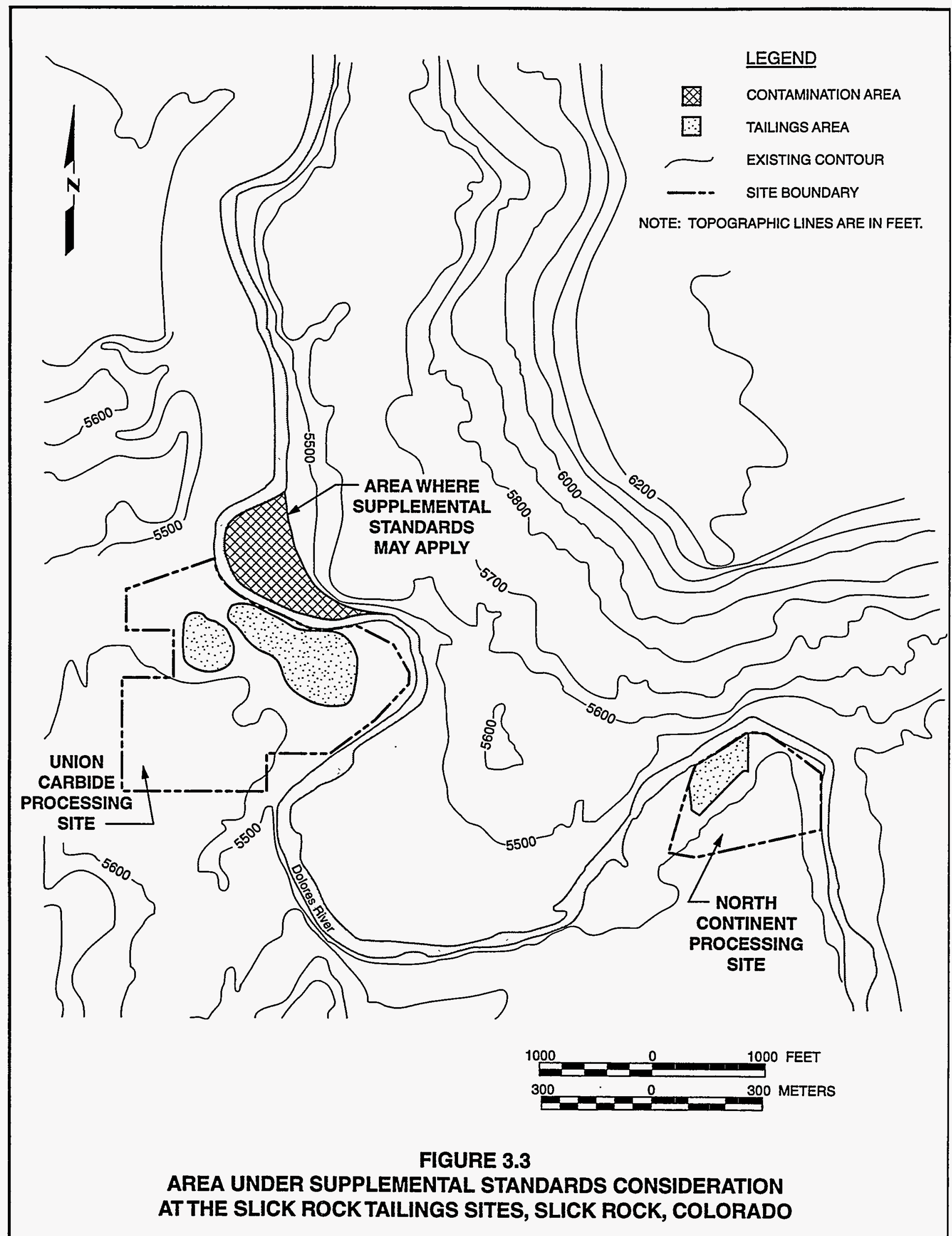




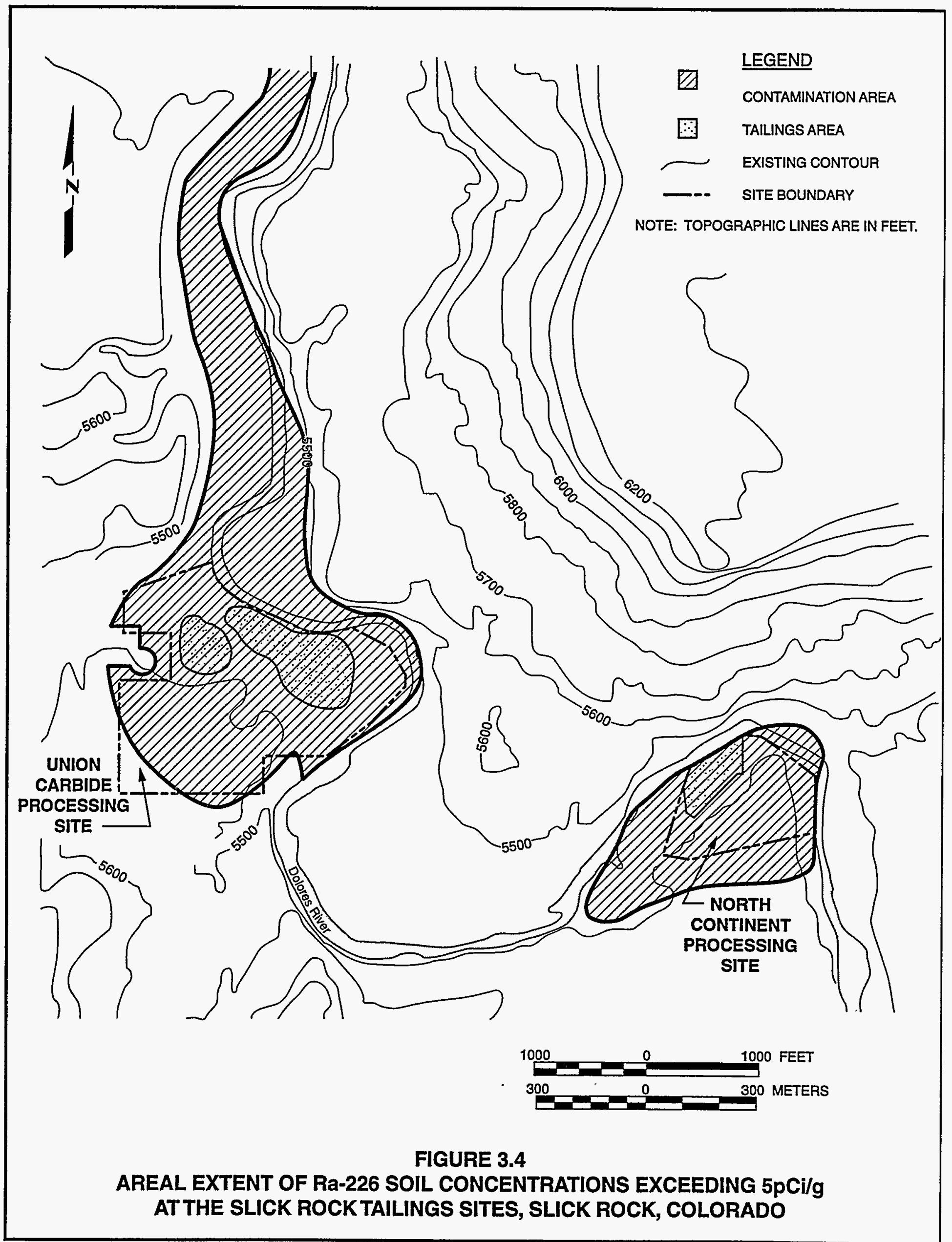


sites). The soil concentration of Ra-226 averaged over any area of 100 square meters $\left(\mathrm{m}^{2}\right)$ would not exceed the background level by more than $5 \mathrm{pCi} / \mathrm{g}$ averaged over the first $15 \mathrm{~cm}$ of soil below the surface, and $15 \mathrm{pCi} / \mathrm{g}$ averaged over $15-\mathrm{cm}$-thick layers of soil more than $15 \mathrm{~cm}$ below the surface. If residual radionuclides other than Ra-226 and its decay products are present in sufficient quantities and concentrations to pose a significant radiation hazard, supplemental standards would be developed and applied with NRC and state concurrence. Remedial action would reduce other residual radioactivity to levels as low as are reasonable to achieve.

- Radon emissions from the disposal cell would be controlled by the construction of a cover system over the tailings and other contaminated materials. The radon emissions would meet EPA standards; emissions from the completed disposal cell would be measured to verify accordance with 40 CFR Part 61. Subpart T. The thickness of the earth barrier was estimated using data on the distribution of radium in the tailings pile, data on the physical properties of the earth cover material, and a computer model, RAECOM.

- The principal features affecting long-term stability of the disposal cell include erosion from a major rainfall event, flooding, and slope stability. The cell's design would withstand the erosive forces of a probable maximum precipitation (PMP) event; that is, the DOE would construct an 8- to 12-in $(20-$ to $30-\mathrm{cm})$ rock cover and contour the cover with a maximum 2-4 percent topsiope and 25 percent ( 4 horizontal to 1 vertical) sideslopes. Slope failure would be protected against by constructing the disposal cell partially below grade and by giving the tailings embankment gentle slopes. The disposal cell has been designed to withstand a maximum credible earthquake.

- The engineering design controls would be effective for up to 1000 years, to the extent reasonably achievable and, in any case, for at least 200 years (40 CFR \$192.01).

In addition, the disposal cell design must comply with the proposed EPA ground water protection standards for inactive uranium mill sites. The DOE has designed a cover system to reduce infiltration from precipitation, protect the radon barrier from frost, and inhibit biointrusion. The cover system would comply with proposed EPA standards for ground water protection.

Ground water would also be protected by an extensive thickness of low permeability claystones and mudstones at the base of the Dakota Sandstone Formation. These natural foundation materials underlying the disposal cell would inhibit the downward migration of contaminated water from the tailings. The tailings and contaminated material would be placed at or below the optimum moisture to reduce seepage. The disposal cell cover system would naturally shed rainfall and runoff and inhibit infiltration of rainfall and runoff through the tailings pile. 
The proposed remedial action would be conducted in compliance with all applicable acts, regulations, and requirements. Some significant requirements to be met during the proposed action are listed below.

- Environmental monitoring during remedial action activities at both the processing and disposal sites is a requirement of the UMTRA Project. A plan to monitor air quality standards would be developed by the RAC and approved by the state of Colorado and San Miguel County before any ground-disturbing activities occurred. Air quality monitoring stations would be strategically located off the sites to monitor airborne particulates, radon, and environmental gamma radiation exposure. This network of monitoring stations would assist in implementing radiological control measures to ensure that public health is adequately and appropriately protected in accordance with DOE Order 5400.5, Radiological Protection of the Public and the Environment.

- An Air Pollution Emissions Notice and Emission Permit would be obtained from the state of Colorado before remedial action began. This permit would require the implementation of a dust control plan to include measures such as covering haul trucks, treating haul roads and disturbed areas with water and water chemical additives, limiting speeds on unpaved haul roads, and stopping work during windy periods.

- A rights-of-way reservation, submitted to the BLM in June 1994, requested 178 ac (72 ha) for the UMTRA Project permanent disposal site and related temporary construction facilities at Burro Canyon; subcontractor trailer sites and parking areas; upgrade of CR-T11; topsoil and excavated soil stockpiles; a wastewater retention basin; access point and access control facilities; an upgrade of turnoff from SH-141 and other support facilities; and county roads around the processing sites.

- Before excavating and collecting borrow materials for the radon barrier from the Disappointment Valley borrow site, the DOE would obtain a free use permit from the BLM. The free use permit would include the planned volume of materials, size of disturbance, access to the site, and reclamation standards. The permit application would include an inventory of cultural resources and threatened and endangered species.

- Archaeological site evaluations have been completed, and the BLM and Colorado State Historic Preservation Office (SHPO) would concur prior to the start of remedial action.

- A threatened and endangered species consultation with the FWS and BLM has been conducted; the results are provided as an attachment to this EA.

- Impacts on endangered fish species in the upper Colorado River Basin and their critical habitat due to the UMTRA Project depletion of water from the 
Dolores River would be mitigated by paying the FWS $\$ 11.98$ per acre-foot of water used, based on the average annual use. These funds are used by FWS to enhance threatened and endangered species habitat. Average annual use is estimated at 75 ac $\mathrm{ft}\left(92,500 \mathrm{~m}^{3}\right)$, which would result in a payment of $\$ 898.50$.

- DOE would apply for a U.S. Army Corps of Engineers (USACE) Section 404 Permit to determine mitigation measures for the impacts to wetlands from the remedial action.

- Under the provisions of the National Historic Preservation Act, the DOE is requesting that the Ute Indian Tribes identify any culturally significant areas that could be affected by the proposed action. To date, the Ute Mountain and Southern Ute Tribes have granted clearances.

- A health physics monitoring plan would be established for construction at both the UC and NC processing sites and the proposed Burro Canyon disposal site. Monitoring stations would be installed and maintained throughout the proposed action to monitor off-site radiation and airborne transport of radon and particulates. The ability of the monitoring program to safeguard public health and the environment and the reliability of the monitoring equipment have been well established on the UMTRA Project.

- The proposed action is not yet addressed in existing San Miguel County or BLM land use plans for the area. A BLM resource management plan for the area emphasizes livestock management but does not address the disposal of uranium mill tailings (Bulinski, 1993; Alexander, 1993). The Dolores River Corridor Management Plan (BLM, 1990) favors the stretch of river that includes Slick Rock over three other sections for location of rights-of-way, utility corridors, management facilities, and other surfacedisturbing activities. Representatives from the UMTRA Project first met with members of the BLM's San Juan Resource Area staff in spring 1993 to discuss the proposed action.

- A San Miguel County Special Use Permit would be applied for to comply with requirements for hauling on county roads.

- A State Highway Permit would be applied for to comply with requirements for hauling on state highways.

- A San Miguel County Conditional Use/Certificate of Designation for Solid Waste Disposal Permit would also be applied for. 


\subsection{AFFECTED ENVIRONMENT}

\subsection{RADIATION CHARACTERISTICS}

The proposed action is to remediate the UC and NC sites by removing tailingscontaminated soil and stabilizing it at an off-site location. The locations of the UC and NC sites and soil concentrations of Ra-226 that exceed $5 \mathrm{pCi} / \mathrm{g}$ are shown in Figure 3.4. Some of the off-pile areas included in these locations are elevated in Ra-226 due to naturally occurring uranium ore. Table 4.1 summarizes the characteristics of the radiologically contaminated materials located at the Slick Rock processing sites. These calculations were based on earlier estimates of volumes of contaminated materials and are equal to or greater than current estimates. Characteristics and associated impacts are, therefore, greater than or equal to what would currently be calculated.

The average background soil radionuclide concentration in the Slick Rock area is $1.4 \mathrm{pCi} / \mathrm{g}$ of Ra-226, $2.5 \mathrm{pCi} / \mathrm{g}$ of thorium-230 (Th-230), and 3 parts per million total uranium (BFEC, 1986). The background radiation exposure rate at the Slick Rock processing sites ranges from 10 to 20 microröentgens per hour $(\mu \mathrm{R} / \mathrm{hr})$ at $3 \mathrm{ft}(0.9 \mathrm{~m})$ above the ground, with an average exposure rate of $13 \mu \mathrm{R} / \mathrm{hr}$ (BFEC, 1986; EG\&G, 1982). The annual average outdoor background radon-222 (Rn-222) concentration was measured to be 0.5 picocuries per liter $(\mathrm{pCi} / \mathrm{L})$ around the Slick Rock area (TAC, 1990a), and $0.6 \mathrm{pCi} / \mathrm{L}$ at the proposed disposal site (TAC, 1991).

Table 4.1 Characteristics of the contaminated materials at the Slick Rock, Colorado, UMTRA processing sites

\begin{tabular}{lcccc}
\hline \multicolumn{1}{c}{ Pile } & $\begin{array}{c}\text { Volume } \\
\left(\mathrm{yd}^{3}\right)\left(\mathrm{m}^{3}\right)\end{array}$ & $\begin{array}{c}\text { Average } \\
\text { Ra-226 } \\
\text { concentration (pCi/g) }\end{array}$ & $\begin{array}{c}\text { Exposure rates } \\
(\mu \mathrm{R} / \mathrm{hr})\end{array}$ & $\begin{array}{c}\text { Range and (average) } \\
\left.\text { radon flux (pCi/m } \mathbf{m}^{2}\right)\end{array}$ \\
\hline $\begin{array}{l}\text { UC pile and } \\
\text { subpile }\end{array}$ & $\begin{array}{c}446,000 \\
(341,000)\end{array}$ & 109 & 76 to 113 & $\begin{array}{c}<1 \text { to } 130 \\
(70)\end{array}$ \\
UC off-pile & $\begin{array}{r}88,000 \\
(67,000)\end{array}$ & 48 & 9 to 526 & 1 to 2.6 \\
$\begin{array}{l}\text { NC pile and } \\
\text { subpile }\end{array}$ & $\begin{array}{r}50,500 \\
(38,600)\end{array}$ & 209 & 13 to 467 & 1 to 700 \\
NC off-pile & 34,300 & 544 & 12 to 1384 & (240) \\
& $(26,200)$ & & & NA \\
\hline
\end{tabular}

${ }^{\text {a } V o l u m e-w e i g h t e d ~ a v e r a g e . ~}$

NA - not available.

$\mu \mathrm{R} / \mathrm{hr}$ - microröentgens per hour.

$\mathrm{pCi} / \mathrm{m}^{2} \mathrm{~s}$ - picocuries per square meter per second. 


\subsection{GEOLOGY}

The UC, NC, and Burro Canyon sites are in the northeastern part of the Colorado Plateau physiographic province, near its boundary with the Southern Rocky Mountains province (Shawe et al., 1968). The Slick Rock region is in the Canyonlands Province between the collapsed salt anticlines and a folded belt that has been dissected by the entrenched meanders of the Dolores River. From the high plains of the Dolores Anticline located southwest of the three sites, the land surface drops to a relatively low elevation along the Dolores River Valley and the synclinal Disappointment Valley. Structurally, the sites are at the south boundary of the Paradox folded and faulted belt. The land surface is deeply incised by the antecedent, generally north-flowing Dolores River, and deeply dissected by tributary stream canyons. Principal physiographic elements within the study area include the Dolores Anticline and the salt core anticlines typified by Paradox Valley, the San Miguel Mountains, and the Uncompahgre Plateau (Figure 4.1).

In ascending order, the lithologic units underlying the Slick Rock region are a Precambrian basement complex $(2000$ to $4000 \mathrm{ft}$ [600 to $1200 \mathrm{~m}$ ] below mean sea level [MSL]), a thick sequence of marine and continental rocks of Cambrian to Cretaceous age, igneous rocks of Tertiary age, and unconsolidated Quaternary deposits. Extremely thick deposits of Permian age occur within the salt core anticlines. Unconsolidated sediments in the region consist of terrace gravels, mud flows, landslides, alluvial fans, soil, colluvium, talus, and floodplain deposits.

The geologic formations underlying the UC and NC sites are the Dolores River alluvium, the Entrada Formation (Slick Rock and Dewey Bridge Members), and the Navajo Sandstone. The Dolores River alluvium is 15 to $30 \mathrm{ft}(4.6$ to $9 \mathrm{~m}$ ) thick beneath the sites. The alluvial deposit under the UC site has lateral dimensions of 2400 by $600 \mathrm{ft}(730$ by $180 \mathrm{~m})$, while the deposit under the NC site is 2400 by $300 \mathrm{ft}(730$ by $90 \mathrm{~m})$. The Entrada Formation, which dips toward the northeast, underlies the river alluvium and outcrops in the area of both tailings piles. It persists to depths of 20 to $170 \mathrm{ft}(6$ to $52 \mathrm{~m}$ ) below land surface. The Navajo Sandstone is fine-grained and relatively homogeneous and underlies the Entrada Formation at depths between 53 and $170 \mathrm{ft}(16$ and $52 \mathrm{~m}$ ). It also outcrops upslope of the UC site (Shawe et al., 1968).

The lower half of the Dakota Sandstone Formation shapes the foundation for the Burro Canyon disposal site and is comprised of shale with thin sandstone beds. This is underlain by the Burro Canyon Formation, which contains lowpermeability mudstone strata interbedded with saturated sandstone units at depth. The uppermost aquifer at the Burro Canyon disposal site is the upper sandstone unit of the Burro Canyon Formation. Approximately 50 to $65 \mathrm{ft} 115$ to $20 \mathrm{~m}$ ) of interbedded mudstone and siltstone will separate the base of the disposal cell from the upper sandstone unit. The Burro Canyon disposal site lies

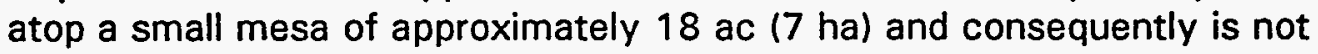
affected by runoff of adjacent drainages (Figure 3.2). 


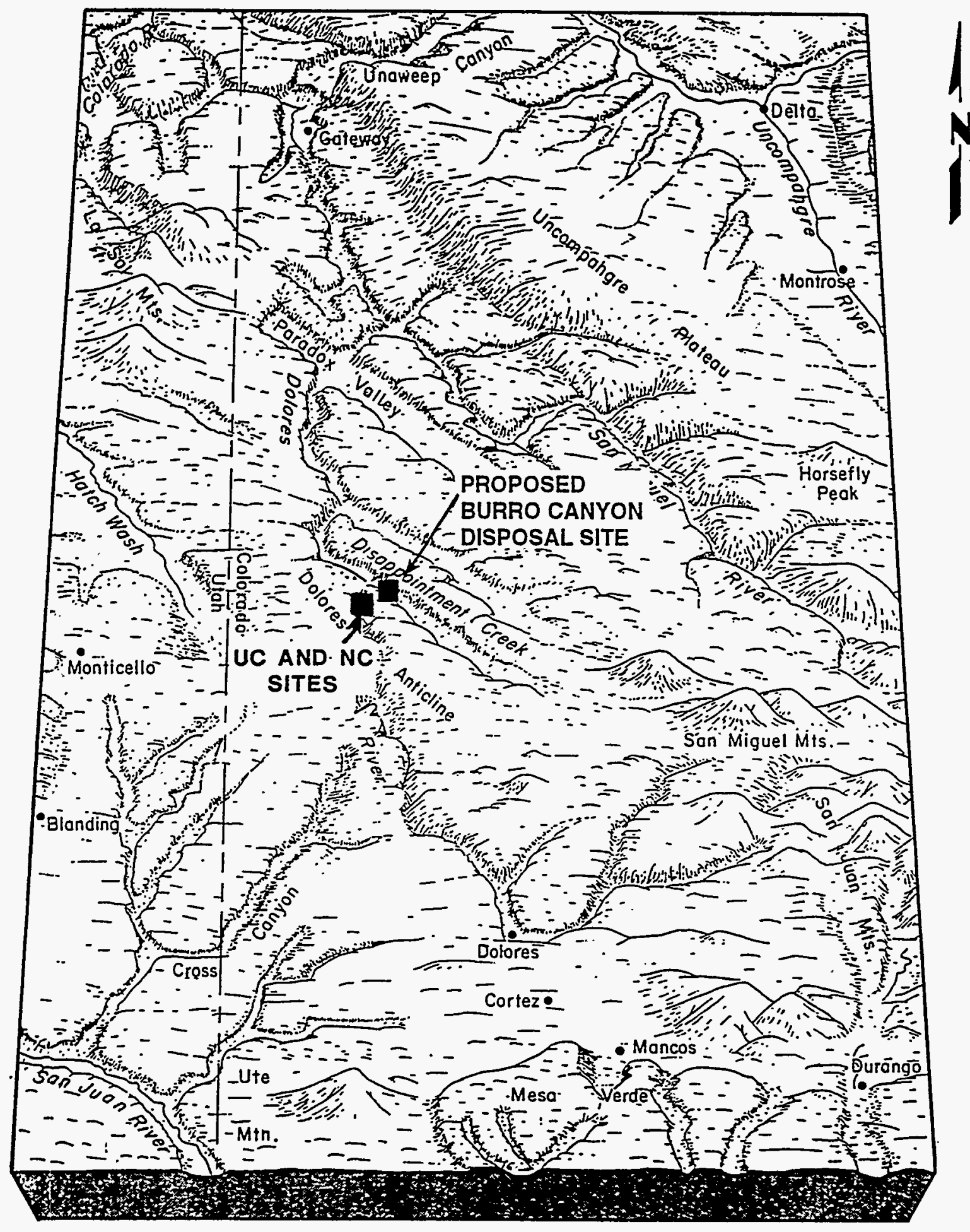

36 0

MILES

REF: HUNT, 1974.

$0 \quad 60$ KILOMETERS

FIGURE 4.1

PHYSIOGRAPHIC FEATURES IN THE REGION OF THE DOLORES RIVER DRAINAGE BASIN 
Economically important mineral resources known in the region are limited to uranium and vanadium as well as oil and gas deposits. The Slick Rock area has been extensively mined for uranium and vanadium, and ore bodies are still present in the area. The principal mine in the area has been the Umetco mine in Burro Canyon, which lies between the NC site and the proposed Burro Canyon disposal site. Mining was discontinued and dewatering of the mine halted in 1983 , when the mine was sold. Uranium and vanadium deposits occurred in a thin zone usually less than $2 \mathrm{ft}(0.6 \mathrm{~m})$ thick at the base of the Salt Wash member of the Morrison Formation. The mine tunnel's nearest approach to the disposal site is $2300 \mathrm{ft}(700 \mathrm{~m})$. Based on mine tunnel evidence and on deposits reported by Umetco in core holes, the depth to the ore zone is approximately $910 \mathrm{ft}(277 \mathrm{~m})$ below the disposal site. Mining of these resources has not taken place in the Slick Rock area in recent years. There are no known oil or gas deposits in the area of the UC or NC sites. The Disappointment Valley borrow site lies within an oil and gas lease (Bulinski, 1994).

\subsubsection{Seismicity}

The UC, NC, and Burro Canyon sites are near the northeast edge of the Colorado Plateau physiographic province. Earthquakes are rare in this province, and seismicity of the interior portion of the province has been characterized as very low (Wong, 1984). The largest instrumentally recorded earthquake ranged from 4.5 to 5.0 on the Richter scale (NGDC/NOAA, 1989). There are nontectonic Quaternary movements associated with the well-defined collapsed structures of the salt core anticline valleys within the area; however, the only potential for significant tectonic activity is from the Uncompahgre Uplift structure, whose nearest approach to the disposal site is $30 \mathrm{mi}(48 \mathrm{~km})$. The basis for this capability is from the 1985 occurrence of a 2.9 magnitude event associated with a known fault, thereby indicating that all faults within that structure are capable (Ely et al., 1986; Kirkham and Rogers, 1981). The effect of the maximum earthquake from the Uncompahgre Uplift has been determined to be less than the design event assumed to occur within $9.3 \mathrm{mi}(15 \mathrm{~km})$ of the disposal site. A detailed analysis showed no indications of any capable faults in the area of the sites. No faults pass through the existing tailings piles or the proposed disposal site. The closest mapped fault lies $0.6 \mathrm{mi}(1.0 \mathrm{~km})$ from the sites and has shown no indication of Quaternary movement. Geologic and geomorphic evidence indicates stability for at least 1000 years.

\subsubsection{Soils}

Surficial deposits at the Burro Canyon disposal site consist mostly of sandy clay and are derived from weathering and erosion of the shale and sandstone of the underlying Dakota Sandstone Formation. Thicknesses observed in test pits range from zero at the perimeter of the small mesa top to $1.5 \mathrm{ft}(0.45 \mathrm{~m})$ in the middle and average less than $1.0 \mathrm{ft}(0.3 \mathrm{~m})$. The soil is locally underlain both by sandstone and by dark gray organic shale. The western slopes of the mesa, which will underlie a portion of the disposal cell, consist of a thin cover (less than $0.5 \mathrm{ft}[0.2 \mathrm{~m}]$ ) of colluvial deposits with no topsoil development. 
The soils at the UC and NC sites are derived from floodplain terrace deposits along the side of the Dolores River canyon. The soils are thin at the NC site, similar to those of the Burro Canyon site, and rest on an eroded bedrock surface. The soils at the UC site below the tailings pile area range in thickness from 2 to $3 \mathrm{ft}(0.6$ to $0.9 \mathrm{~m})$ and grade into the generally fine-grained, unconsolidated floodplain sediments.

\subsubsection{Borrow sites}

The Dolores River borrow site is on an alluvial terrace of the Dolores River. Deposits of gravels, cobbles, and boulders are structurally similar to the modern channel gravels. This site is underlain by the Entrada Formation and Navajo Sandstones.

The Disappointment Valley borrow site consists of loose, brown, dry, sandy, and silty clay overlying hard, dark green-gray, and fissile Mancos Shale. The depth of this overlying material ranges from $1 \mathrm{ft}(0.3 \mathrm{~m})$ at the north-central end of the borrow site to 12 or $13 \mathrm{ft}(3.7$ or $4.0 \mathrm{~m})$ in the southwest portion of the site. The northwest corner of the borrow site also exhibits up to $10 \mathrm{ft}(3 \mathrm{~m})$ of this sandy clay.

\subsection{GROUND WATER}

Ground water conditions at the Slick Rock processing sites are highly dependent on local structural, stratigraphic, and topographic features.

The uppermost aquifer at the UC and NC sites consists of Dolores River alluvium, underlain by Entrada Formation (Slick Rock and Dewey Bridge Members) and Navajo Sandstone. Ground water movement is unconfined in the Dolores River alluvium. In the Entrada Formation, ground water is expected to be semiconfined when medium- to coarse-grained sediments are interbedded with clayey siltstones and shales; confined conditions are expected when only low-permeability siltstones and shales exist. In the Navajo Sandstone, ground water is expected to be semiconfined to confined; the relative amount of hydraulic connection between the Navajo and Entrada Formations is dependent on the permeability of the Navajo Sandstone and the overlying materials of the Entrada Formation, as well as on the variations in the contacts between formations. Table 4.2 provides additional information on ground water below the UC and NC processing sites.

Ground water elevations in the alluvium, Entrada Formation, and Navajo Sandstone remain relatively constant, regardless of the time of year.

\subsubsection{Description of local hydrogeology}

The Dolores River alluvium is composed of unconsolidated clayey sands, sandy gravels, and cobbles from the ground surface to an approximate depth of $20 \mathrm{ft}$ $(6 \mathrm{~m})$ at both the UC and NC sites. The Entrada Formation underlies the 
Table 4.2 Processing sites ground water data

\begin{tabular}{|c|c|c|c|}
\hline Characteristic & $\begin{array}{c}\text { Dolores River } \\
\text { alluvium }\end{array}$ & Entrada Sandstone & Navajo Sandstone \\
\hline $\begin{array}{l}\text { Average hydraulic } \\
\text { conductivity (UC) }\end{array}$ & $\begin{array}{l}14 \mathrm{ft} / \mathrm{day} \\
\left.14.9 \times 10^{-3} \mathrm{~cm} / \mathrm{s}\right)\end{array}$ & Not determined & $\begin{array}{l}2.4 \times 10^{-2} \mathrm{ft} / \mathrm{day} \\
\left(8.5 \times 10^{-6} \mathrm{~cm} / \mathrm{s}\right)\end{array}$ \\
\hline $\begin{array}{l}\text { Average hydraulic } \\
\text { conductivity (NC) }\end{array}$ & $\begin{array}{l}23 \mathrm{ft} / \mathrm{day} \\
\left(8.1 \times 10^{-3} \mathrm{~cm} / \mathrm{s}\right)\end{array}$ & Not determined & Not determined \\
\hline $\begin{array}{l}\text { Average linear ground } \\
\text { water velocity (UC) }\end{array}$ & $\begin{array}{l}160 \mathrm{ft} / \mathrm{yr} \\
\left(1.5 \times 10^{-4} \mathrm{~cm} / \mathrm{s}\right)\end{array}$ & Not determined & $\begin{array}{l}1 \mathrm{ft} / \mathrm{yr} \\
\left(1 \times 10^{-6} \mathrm{~cm} / \mathrm{s}\right)\end{array}$ \\
\hline $\begin{array}{l}\text { Average linear ground } \\
\text { water velocity (NC) }\end{array}$ & $\begin{array}{l}100 \mathrm{ft} / \mathrm{yr} \\
\left(.97 \times 10^{-4} \mathrm{~cm} / \mathrm{s}\right)\end{array}$ & Not determined & Not determined \\
\hline Background pH & $\begin{array}{l}\text { Near neutral } \\
(6.9 \text { to } 7.7)\end{array}$ & $\begin{array}{l}\text { Slightly alkaline } \\
(7.8 \text { to } 8.0)\end{array}$ & $\begin{array}{l}\text { Neutral } \\
7.2 \text { to } 7.8\end{array}$ \\
\hline Background TDS & $\begin{array}{l}622 \mathrm{mg} / \mathrm{L} \text { to } \\
1180 \mathrm{mg} / \mathrm{L}\end{array}$ & $\begin{array}{l}147 \mathrm{mg} / \mathrm{L} \text { to } \\
1990 \mathrm{mg} / \mathrm{L}\end{array}$ & $\begin{array}{l}229 \mathrm{mg} / \mathrm{L} \text { to } \\
1530 \mathrm{mg} / \mathrm{L}\end{array}$ \\
\hline
\end{tabular}

$\mathrm{cm} / \mathrm{s}=$ centimeters per second.

$\mathrm{mg} / \mathrm{L}=$ milligrams per liter.

alluvium in the Dolores River floodplain to depths ranging from 20 to $170 \mathrm{ft}$ $(6$ to $52 \mathrm{~m})$. Two members of the Entrada Formation are present: the Slick Rock Member and the Dewey Bridge Member. The erosive Slick Rock Member is composed of eroded light brown, fine-grained sandstone and reddish-brown sandy shale. The Dewey Bridge Member consists of reddish-brown clayey siltstone, very fine-grained sandstone, and shale. The Navajo Sandstone, composed of light-brown to reddish-brown fine-grained sandstone, underlies the Entrada Formation at depths ranging from 53 to $170 \mathrm{ft}(16$ to $52 \mathrm{~m})$. The thickness of the Navajo Sandstone has not been determined at the Slick Rock processing sites.

The depth to ground water at both processing sites ranges from 5 to $20 \mathrm{ft} 12$ to $6 \mathrm{~m}$ ) in wells screened in the alluvium and is approximately the same as the surface water levels of the Dolores River. Ground water flow in the alluvium is generally to the north. The alluvial aquifer is recharged upstream by seepage from the Dolores River and by precipitation. Ground water discharges from the alluvium into the Dolores River.

The depth to ground water is approximately 27 to $47 \mathrm{ft}(8.2$ to $14 \mathrm{~m}$ ) in monitor wells screened in the Dewey Bridge Member of the Entrada Formation (none of the Entrada wells are screened in the Slick Rock Member). The Entrada Formation is capable of producing a source of usable water, as evidenced by a gravity flow collector system tapping the formation on a canyon wall west of the UC processing site (DOE, 1994). However, the hydraulic characteristics of the Entrada Formation have not been directly tested. Information available for 
ground water movement in the Entrada Formation is limited to the UC site because no monitor wells are screened in the Entrada Formation at the NC site.

In monitoring wells screened in the Navajo Sandstone, the depth to ground water is approximately $57 \mathrm{ft}(17 \mathrm{~m})$. The direction of ground water flow in the Navajo Sandstone is generally to the north at both processing sites. Static ground water levels suggest that ground water in the Navajo Sandstone is unconfined to confined, depending upon the permeability and thickness of the overlying hydrostratigraphic units.

\subsubsection{Ground water quality}

Background ground water quality is defined as the quality of ground water that would be expected at the processing sites if uranium processing had not occurred. Concentrations or activities of chromium, molybdenum, uranium, and Ra-226 and -228 have exceeded the maximum concentration limits (MCL) listed in the proposed EPA ground water protection standards (Subpart $A$ of 40 CFR Part 192) in one or more background alluvial monitor wells (DOE, 1994).

Baseline ground water quality is defined as the representative water quality in a monitor well that has been influenced by uranium processing activities (DOE, 1989). Average total dissolved solids (TDS) concentrations in baseline alluvial ground water are approximately three times those of background. The primary regulated hazardous constituents of concern in the Dolores River alluvium are molybdenum, nitrate, selenium, and uranium at the UC processing site and selenium and uranium at the NC processing site. The baseline water quality of the Entrada Formation may also be affected by the uranium processing activities for the following reasons:

- The average concentrations of TDS in the baseline Entrada Formation monitor wells are approximately three times those observed in the background Entrada Formation monitor wells.

- Concentrations of selenium exceed the MCL and background.

Baseline water quality in the Navajo Sandstone does not appear to be affected by the tailings processing activities. TDS, $\mathrm{pH}$, and the regulated constituents show minimal variation between background and baseline water quality.

\subsubsection{Ground water use}

A February 1994 well survey indicates 18 private wells within a 2-mi (3-km) radius of the Slick Rock UC and NC processing sites. Fourteen of these wells are registered with the Colorado Division of Water Resources; the remaining four are nonregistered. Well permit information indicates that the nearby private wells are screened in the alluvium, Entrada, and Navajo Sandstone Formations. The survey also shows that of the 18 private wells, 2 are actively used, 11 were disconnected from power sources and their subsurface integrity is 
unknown, 3 could not be located in the field and are presumed to be sealed, and the status of 2 registered wells located approximately $2 \mathrm{mi}(3 \mathrm{~km})$ east (upgradient of the processing sites) is unknown because of limited roadway access. Three private wells are downgradient of the UC site and are expected to be beyond the reach of the contaminant plume, as evidenced by the water quality in downgradient alluvial DOE monitor wells. The remaining wells are upgradient or crossgradient of the UC site. A ground water flow boundary appears to follow the course of the Dolores River and is expected to hydrologically separate three wells from the NC tailings, which are on the opposite side of the Dolores River from the private wells.

In addition to the 18 private wells, a collector system that taps the Entrada Formation and could be accessed by cattle is located along a cliff face approximately $1500 \mathrm{ft}(450 \mathrm{~m})$ west (upgradient) of the UC site.

Staff from the BLM and U.S. Geological Survey have reported (February 1994) that they are unaware of any additional ground water users within $2 \mathrm{mi}(3 \mathrm{~km})$ of the Slick Rock processing sites.

\subsubsection{Disposal site}

One unsaturated unit and three saturated units are present below the Burro Canyon disposal site. The unsaturated unit immediately underlying the site consists of the Dakota Sandstone Formation and the Burro Canyon mudstone. The three saturated sandstone units begin at approximate depths of 100,200 , and $300 \mathrm{ft}(30,60$, and $90 \mathrm{~m})$. These units are described as the upper, middle, and lower units, respectively. Each unit is composed of fine-to medium-grained sandstone layers 25 to $75 \mathrm{ft}(7.6$ to $23 \mathrm{~m})$ thick. The units are hydrogeologically separated from each other by unsaturated interbedded mudstone and siltstone sequences. Ground water flow in the upper sandstone unit is semiconfined and hydrogeologically isolated from the underlying waterbearing units, which are the middle and lower units of the Burro Canyon Formation. Table 4.3 provides additional information on the ground water below the proposed Burro Canyon disposal site.

Table 4.3 Proposed disposal site ground water data

\begin{tabular}{|c|c|c|c|c|c|}
\hline \multirow[b]{2}{*}{ Characteristic } & \multirow{2}{*}{$\begin{array}{c}\text { Dakota } \\
\text { Sandstone }\end{array}$} & \multirow{2}{*}{$\begin{array}{c}\text { Burro Canyon } \\
\text { Mudstone }\end{array}$} & \multicolumn{3}{|c|}{ Burro Canyon Formation sandstone units } \\
\hline & & & Upper & Middle & Lower \\
\hline $\begin{array}{l}\text { Hydraulic } \\
\text { conductivity }\end{array}$ & $\begin{array}{l}4 \times 10^{-1} \mathrm{ft} / \mathrm{day} \\
\left(2 \times 10^{-4} \mathrm{~cm} / \mathrm{s}\right)\end{array}$ & $\begin{array}{l}6 \times 10^{-3} \mathrm{ft} / \text { day } \\
\left(2 \times 10^{-6} \mathrm{~cm} / \mathrm{s}\right)\end{array}$ & $\begin{array}{l}4 \times 10^{-2} \mathrm{ft} / \mathrm{day} \\
\left(1 \times 10^{-5} \mathrm{~cm} / \mathrm{s}\right)\end{array}$ & $\begin{array}{l}9 \times 10^{-2} \mathrm{ft} / \mathrm{day} \\
\left(3 \times 10^{-5} \mathrm{~cm} / \mathrm{s}\right)\end{array}$ & $\begin{array}{l}5 \times 10^{-3} \mathrm{ft} / \mathrm{day} \\
\left(2 \times 10^{-6} \mathrm{~cm} / \mathrm{s}\right)\end{array}$ \\
\hline $\begin{array}{l}\text { Average linear } \\
\text { ground water } \\
\text { velocity }\end{array}$ & NA & NA & $\begin{array}{c}6 \mathrm{ft} / \mathrm{yr} \\
\left(6 \times 10^{-6} \mathrm{~cm} / \mathrm{s}\right)\end{array}$ & $\begin{array}{c}2 \mathrm{ft} / \mathrm{yr} \\
\left(2 \times 10^{-6} \mathrm{~cm} / \mathrm{s}\right)\end{array}$ & $\begin{array}{c}1.0 \mathrm{ft} / \mathrm{yr} \\
\left(1 \times 10^{-6} \mathrm{~cm} / \mathrm{s}\right)\end{array}$ \\
\hline
\end{tabular}

NA - not applicable. 
The Dakota Sandstone Formation (immediately underlying the proposed disposal site) and the Burro Canyon mudstone are not water-bearing. The saturated hydraulic conductivities of the unsaturated Dakota Sandstone Formation bedrock and the unsaturated Burro Canyon mudstones were determined by field packer tests. The packer tests indicate that the saturated horizontal hydraulic conductivity of the sandstone in the Dakota Sandstone Formation is moderate and is several orders of magnitude greater than that of the Burro Canyon Formation. The hydraulic conductivity decreases with depth in the Burro Canyon mudstone, reflecting decreased fracture permeability with depth.

The upper sandstone unit of the Burro Canyon Formation is the first saturated unit and is the uppermost aquifer at the Burro Canyon disposal site. The upper sandstone unit has Class III ground water, meaning that ground water is not a current or potential source of drinking water because the quantity of water available is less than 150 gallons per day (gpd) $\left(6.6 \times 10^{-3}\right.$ liters per second $[\mathrm{L} / \mathrm{s}])$. Pumping tests were conducted in wells screened in the upper sandstone unit. However, the wells could not sustain the 150-gpd $\left(6.6 \times 10^{-3} \mathrm{~L} / \mathrm{s}\right)$ rate for an extended period of time. The top of the upper sandstone unit occurs from 50 to $100 \mathrm{ft}(20$ to $30 \mathrm{~m}$ ) below the ground surface.

The top of the middle sandstone unit of the Burro Canyon Formation occurs at a depth between 140 and $190 \mathrm{ft}(42$ and $58 \mathrm{~m})$ below the ground surface in the vicinity of the disposal cell footprint. The middle sandstone unit is a confined aquifer approximately $50 \mathrm{ft}(15 \mathrm{~m})$ thick. Because the middle sandstone unit is confined by approximately $140 \mathrm{ft}(43 \mathrm{~m})$ of overlying mudstone, claystone, and fine-grained sandstone, there is a substantial upward hydraulic potential.

Monitor wells screened in the middle Burro Canyon Sandstone unit have ground water (potentiometric surface) levels that average $40 \mathrm{ft}(12 \mathrm{~m})$ above the top of this unit.

The lower water-bearing sandstone unit of the Burro Canyon Formation is $39 \mathrm{ft}$ $(12 \mathrm{~m})$ thick beneath the disposal cell, and the top of the unit is located approximately 250 to $300 \mathrm{ft}(76$ to $91 \mathrm{~m}$ ) below the ground surface. Ground water in this unit is confined by the thick sequence of overlying low-permeability mudstones and siltstones of the Burro Canyon Formation. Because of the extremely low velocity and well yield in the lowermost sandstone unit, the lower sandstone unit is not an aquifer.

Vertical recharge and discharge from and to the Burro Canyon Sandstone units are restricted because the low-permeability interbedded claystone and siltstone strata impede infiltration into the water-bearing units. The source of recharge to the uppermost aquifer is approximately 0.25 to $0.75 \mathrm{mi}(0.40$ to $1.21 \mathrm{~km})$ northeast of the site, where the sandstone beds outcrop along the east limb of the Disappointment syncline, intercepting tributaries to the Nicholas Wash drainage system. Ground water then flows to the southeast and eventually diffuses (discharges) into the surrounding geologic strata south of the Burro Canyon disposal site. 
Background ground water quality in each hydrostratigraphic unit within the Burro Canyon Formation was determined from monitoring ground water in wells completed in each unit. In general, ground water $\mathrm{pH}$ is fairly neutral, and concentrations of TDS tend to decrease with depth; the average TDS concentration was 766 milligrams per liter (mg/L) in the upper sandstone, $\mathbf{5 7 5}$ $\mathrm{mg} / \mathrm{L}$ in the middle sandstone, and $348 \mathrm{mg} / \mathrm{L}$ in the lower sandstone. The only naturally-occurring hazardous constituents exceeding the proposed EPA MCLs are selenium and Ra-226 and -228 in the upper sandstone unit and Ra-226 and -228 in the middle sandstone unit. These exceedances have occurred in one or more wells.

There are no known registered wells or private water users within the uppermost aquifer (upper sandstone unit of the Burro Canyon Formation) in a $2-\mathrm{mi}(3-\mathrm{km})$ radius of the Burro Canyon disposal site.

\subsection{SURFACE WATER AND FLOOD HAZARD}

The Dolores River originates in the western San Juan Mountains near Hermosa Peak. Elevations in the basin vary from $5400 \mathrm{ft}(1600 \mathrm{~m})$ above MSL at the processing sites to over $12,000 \mathrm{ft}(3700 \mathrm{~m})$ above MSL at the headwaters near Hermosa Peak. Major tributaries to the Dolores River include Disappointment Creek, The Glades, and the Narraguinnep upstream of the processing sites, and the San Miguel River and Summit Canyon downstream of the sites. The Dolores River drains into the Colorado River $10 \mathrm{mi}(16 \mathrm{~km})$ west of the Colorado-Utah border. Most major flow events on the Dolores River occur during the spring or early summer as a result of snowmelt or the combination of snowmelt and rainfall events.

Since March 1984, flow of the Dolores River in the vicinity of the former processing site has been regulated by McPhee Dam. In addition to McPhee Dam and McPhee Reservoir, located 55 river miles $(88 \mathrm{~km})$ east of the former processing site, flow on the Dolores River is also controlled by numerous diversions for irrigation. Average maximum releases from McPhee Reservoir are 4000 cubic feet per second $\left(\mathrm{ft}^{3} / \mathrm{s}\right)\left(100\right.$ cubic meters per second $\left.\left[\mathrm{m}^{3} / \mathrm{s}\right]\right)$, and the required minimum release from the reservoir is $80 \mathrm{ft}^{3} / \mathrm{s}(2.3 \mathrm{~m} / \mathrm{s})$. Some of the larger intermittent tributaries of the Dolores river, including The Glade, Narraguinnep, and Disappointment Creek, contribute high volumes of runoff to the Dolores River during the late spring, and flow rates of the Dolores River in the vicinity of the former processing sites can exceed $5500 \mathrm{ft}^{3} / \mathrm{s}\left(160 \mathrm{~m}^{3} / \mathrm{s}\right)$.

This section describes the environment at the processing sites and at the proposed disposal site and borrow sites. Attachments 1 and 2 provide the biological assessment and the floodplains and wetlands assessment performed for this EA. 


\subsubsection{Processing sites}

The UC and NC sites are in the modern floodplain of the Dolores River. Both sites are within large meander loops of the river. A rock-covered earthen dike was placed along the base of the UC pile next to the river to prevent erosion.

Ephemeral drainages near the UC pile include the Summit Canyon Wash, which joins the Dolores River $650 \mathrm{ft}(200 \mathrm{~m})$ downstream of the pile, and Corral Draw, which flows into the Dolores River $1000 \mathrm{ft}(300 \mathrm{~m})$ south of the pile. Ephemeral flows of Corral Draw are constrained within the main channel by banks composed of well-cemented terrace gravels overlying sandstone bedrock. An ephemeral gully between the mill site and the gas sweetener plant drains a small area of Poverty Flat. The area west of the former UC mill site and north of Poverty Flat drains to a small ephemeral channel that flows $250 \mathrm{ft}(76 \mathrm{~m})$ west of CR-S8 and joins the Summit Canyon Wash $600 \mathrm{ft}(200 \mathrm{~m})$ north of the inactive gas sweetener plant. The UC tailings pile is gently rolling and sparsely vegetated. Some rill formation is evident on the surface of the pile.

The closest ephemeral stream to the NC site flows out of Hanks Pocket and drains into the Dolores River $1000 \mathrm{ft}(300 \mathrm{~m})$ downstream of the tailings pile. Surface runoff across the site is limited to overland flow resulting from precipitation events occurring on or immediately above the site. The tailings pile is undergoing erosion from surface runoff, wind, downhill creep, and flooding of the Dolores River. The surface of the pile is partially vegetated and strongly gullied.

A 100-year flow of $84,200 \mathrm{ft}^{3} / \mathrm{s}\left(2380 \mathrm{~m}^{3} / \mathrm{s}\right)$ was determined for the Dolores River at Slick Rock using methods described in Attachment 2, Floodplain/ Wetlands Assessment. The results of this analysis indicate that the bases of the UC and NC piles are within the 100-year floodplain.

DOE monitoring of the water quality of the Dolores River has been conducted. Results show that water quality has not been affected by the two tailings piles or by previous processing activities. Significant flows in Disappointment Creek are associated with summer thunderstorms and spring runoff resulting from the combined effects of rainfall and snowmelt on upland watersheds.

\subsubsection{Disposal site}

The Burro Canyon site is above the 1000-year floodplain of the Dolores River on top of a stable, low-lying mesa $1.5 \mathrm{mi}(2.4 \mathrm{~km})$ north, approximately $400 \mathrm{ft}$ $(122 \mathrm{~m})$ higher than the Dolores River. Flooding is not a concern because the site is $60 \mathrm{ft}(18 \mathrm{~m})$ higher in elevation than the ephemeral tributary north of the site. The proposed buffer zone shows the area where the upper layers of the Dakota Formation outcrop and provide protection from encroachment by scarp retreat. 
The only drainage that crosses the Burro Canyon site is a shallow swale that originates on the mesa. No runoff except that which falls directly on the mesa would affect the disposal cell.

\subsubsection{Borrow sites}

The proposed Dolores River borrow site lies in the modern floodplain of the Dolores River. No ephemeral channels cross the site or drain into the river near the site. Runoff across the site is limited to overland flow resulting from precipitation on the site and flows draining from the cliffs northeast of the site to the Dolores River.

The proposed Disappointment Valley borrow site lies adjacent to an ephemeral tributary to the perennial Disappointment Creek. Discharge in the $1.5-\mathrm{mi}^{2}(3.9-$ $\mathrm{km}^{2}$ ) drainage area of this ephemeral wash is primarily a result of summer thunderstorm events. The ephemeral tributary has no flow at most times of the year, although some flow occurs from precipitation associated with summer thunderstorms. Major flow events can occur during late snow melt when spring rains add to quick snow melt in the upper water shed.

The quality of surface water in the vicinity of the Dolores River borrow site is similar to the surface water quality near the processing sites. Surface waters in the ephemeral washes near the Disappointment Valley borrow site are generally naturally poor in quality and are not potable due to high concentrations of TDS and chlorides.

\subsubsection{Surface water uses, classifications, and standards}

Public water reserve withdrawals from the Dolores River for agricultural purposes are minimal downstream from the Slick Rock processing sites to Bedrock, Colorado (45 mi [72 km]), and upstream to the McPhee Reservoir (55 $\mathrm{mi}[88 \mathrm{~km}])$. The state of Colorado has classified the Dolores River in the area of the Slick Rock processing sites as suitable for domestic water supply and for agricultural purposes. In addition, the state has rated the Dolores River as Class 1 recreational waters (i.e., suitable for rafting) and as Class 1 for cold water aquatic life (Colorado Department of Public Health and Environment [CDPHE], 1986).

Agricultural use of Disappointment Creek consists of several small ponds and limited diversions for irrigation. There are no users of the waters in the ephemeral wash that occurs near the Disappointment Valley borrow site. Based on the state of Colorado classification, Disappointment Creek and its tributaries are Class 2 recreational waters (i.e., water suitable for activities that do not require primary contact) and are Class 2 warm water aquatic habitat (CDPHE, 1986). 
The UC and NC sites are in a topographically complex area consisting of the Dolores River Valley and surrounding steep canyon walls and hillsides. The proposed Burro Canyon disposal site, approximately 2 air mi $(3.2 \mathrm{~km})$ from the NC site, is outside of the Dolores River Canyon in an adjacent broad synclinal valley positioned on top of a small mesa. The region has an arid, continental climate with low precipitation and humidity, high evaporation, and large temperature variations. Topographic channeling of winds affects the climate and dispersion potential at the two processing sites. Because of the high plateau of the Dolores Anticline immediately overlooking the UC, NC, and Burro Canyon sites from the south and east, the climate is typically drier and warmer than the nearby communities of Egnar, Dove Creek, Monticello, and Cortez that lie on this plateau (Shawe et al., 1968). There are no weather stations near these sites. Due to the canyon topography in which these sites are located, weather data from Montrose or Paradox, Colorado, are not relevant.

High-intensity thunderstorms occur in the general area and in the past have resulted in erosion of the tailings piles at both processing sites. The average annual precipitation has been estimated at 7 inches $(18 \mathrm{~cm})$ per year. Thunderstorm activity and precipitation are greatest during August and September (FBDU, 1981).

Wind flow data are not available for the UC, NC, and Burro Canyon sites. The average wind speed in the Slick Rock area is estimated to be $3.4 \mathrm{mi}$ per hour (5.5 km per hour) (FBDU, 1981).

No air quality data are available that would be relevant to the UC or NC areas. Since the area is rural, there are few industries to affect air quality (BLM, 1990).

\subsection{FLORA AND FAUNA}

The UC, NC, Burro Canyon, and borrow sites are located in the Great Basin sagebrush habitat of the Colorado Plateau. The two tailings piles and the Dolores River borrow site are in the Dolores River valley, with its dense growth of riparian vegetation along the river flanked by steep juniper and desert shrub-covered slopes. The Burro Canyon disposal site and Disappointment Valley borrow site are in desert shrub plant communities.

\subsubsection{Processing sites}

\section{Vegetation}

Six plant community types were observed in the area of the UC and NC sites: disturbed grassland, desert shrub, and four riparian plant communities.

Disturbed grassland is found on the tailings piles and in disturbed areas. Grass such as crested wheatgrass, indian ricegrass, and red brome are common. 
Scattered shrubs such as fourwing saltbush, rabbitbrush, and broom snakeweed also occur in these areas. The shrub density is greatest on the NC tailings pile.

The desert-shrub plant community type is characterized by scattered sagebrush, rabbitbrush, and broom snakeweed. Patches of grass and herbs are the predominant ground cover.

The riparian plant communities are along the Dolores River. A dense willow/saltcedar shrub community grows in bands next to the river. Farther back from the river, the upper riparian grasslands are dominated by grass and scattered shrubs such as big sagebrush, greasewood, New Mexico privet, squawbush, saltcedar, and Russian olive. The upper riparian shrub community contains more shrubs than the upper riparian grassland type, and its dense ground cover consists mostly of grass. The remaining riparian plant community is dominated by fairly large cottonwoods. The ground cover is dense, and shrubs such as squawbush, big sagebrush, and box elder are scattered throughout. These riparian plant communities are described in greater detail in Attachment 2, Floodplain/Wetlands Assessment.

\section{Fisheries and wildlife}

Twelve species of fish inhabit the Dolores River. Native species such as the flannelmouth sucker and roundtail chub are common, as are nonnative fish species, including the red shiner and flathead minnow. The majority of fish in the river are native species. The flow characteristics of the river have been altered by the irrigation withdrawals from McPhee Reservoir upstream of the processing sites, which have reduced high spring flows and augmented base summer, fall, and winter flows.

Wildlife found at the processing sites is a mixture of species that occur in riparian and desert-shrub habitats. The sagebrush lizard and whiptail are common reptiles observed on the processing sites. A total of 77 species of birds have been observed: the yellow-breasted chat, yellow warbler, and blue grosbeak are common species in the riparian zone. Birds of prey observed in this area include the kestrel and the red-tailed hawk. Approximately 32 species of mammals may occur at or near the processing sites. Beaver signs (cuttings) have been observed along the river, and mule deer occur in the area. The desert bighorn sheep also occurs along the steep slopes of the Dolores River Valley and along the river itself in the area of the UC and NC sites. More details regarding the fisheries and wildlife at and near the tailings sites appear in Attachments 1 and 2 .

\subsubsection{Disposal site}

The Burro Canyon disposal site area is in an upland area above the Dolores River Valley. The site itself is grass-dominated, with widely scattered herbs such as scarlet globe mallow also observed. Widely scattered shrubs occur in the area, with fourwing saltbush being the most common species observed. Prickly pear is also fairly common. The disposal site area is surrounded by low ridges 
covered with pinon pine/juniper woods. Big sagebrush, black sagebrush, and broom snakeweed are common shrubs. Species of cactus observed in these woods are claret cup, Simpson bell cactus, and Whipple's claw cactus.

The western meadowlark and the horned lark are the most common nesting bird species recorded. Other species observed are the magpie, pinon jay, and chipping sparrow. Deer and elk droppings have been widely scattered throughout this area, and the disposal site is within deer and elk wintering range. Desert bighorn sheep also use the area. A prairie dog town covers most of the disposal site.

\subsubsection{Borrow sites}

The plant community types at the Dolores River borrow site are cleared pasture dominated by grass and desert shrub dominated by species such as big sagebrush and rabbitbrush. Clumps of grass are the most common ground cover in the desert-shrub habitat. The Disappointment Valley borrow site is on relatively flat terrain in the desert-shrub habitat. Black greasewood is the most common species, with widely scattered fourwing saltbush and rabbitbrush also observed.

Wildlife typical of desert-shrub habitat occurs at these borrow sites. The mule deer is the most abundant game species at the Dolores River borrow site. Mule deer, pronghorn antelope, and elk occur at the Disappointment Valley borrow site area. This site is within a designated deer and elk winter concentration area. A prairie dog town occurs just north of the Disappointment Valley borrow site.

\subsubsection{Threatened and endangered species}

Through consultation with the Fish and Wildlife Service and the Colorado Division of Wildlife, 11 species were determined to have the potential to occur at or near the sites (refer to Table 3.1 of Attachment 1). A detailed description of threatened and endangered (T\&E) species appears in Attachment 1; below is a summary.

The endangered humpback chub, bonytail chub, and razorback sucker have not been found in the Dolores River. The Colorado squawfish occurs near the mouth of the river $120 \mathrm{mi}(193 \mathrm{~km})$ downriver from the processing sites. The bald eagle occurs sporadically and in small numbers in the area of the processing sites during the winter (December through mid-April), and over the last few years has been observed roosting in cottonwoods along the river near the UC site and on well casings and trees at the Burro Canyon disposal site area. A winter roost site is approximately $1.5 \mathrm{mi}(2.4 \mathrm{~km})$ south of the Disappointment Valley borrow site along Disappointment Creek. Up to 10 eagles have been observed at this roost site in recent years. Two nest sites of the peregrine falcon are active along the Dolores River, both of which are approximately $8 \mathrm{mi}(13 \mathrm{~km})$ from the processing sites. The absence of prairie dog towns at the tailings, the Disappointment Valley borrow site, and Dolores 
River borrow sites presupposes that the black-footed ferret would not occur in these areas. A prairie dog town occurs at the disposal site; therefore, a blackfooted ferret survey would be conducted prior to ground disturbance. If blackfooted ferrets were found, the FWS would be consulted.

The southwestern willow flycatcher has been proposed as an endangered species (58 FR 39495). This species has not been recorded near the sites, but due to the presence of nesting habitat, it may use the sites in the future. The remaining three species are federal candidate species. Neither the white-faced ibis nor the black tern, nor their nesting habitats, were observed at or near the sites. The river otter was reintroduced to the Dolores River in 1988; this species uses the Dolores River at and near the processing sites and Dolores River borrow site.

\subsubsection{Wetlands}

Riparian plant communities along the Dolores River include the dense growth of willow and saltcedar, a plant community type the USACE classifies as wetlands. A more detailed description of the riparian plant communities along the Dolores River appears in Attachment 2.

\subsection{HISTORIC AND CULTURAL RESOURCES}

People first entered the Slick Rock area in the Paleo-Indian Period, 12,000 to 7500 years before the present. The people of this time were nomadic game hunters who are now known for their distinctive weapons. The post-glacial Archaic Period replaced the Paleo-Indian Period. The people of this time were hunters and gatherers who made pottery. This period lasted into historic times until the Ute Indian Tribe left the area in the 1880s (BLM, 1982).

In the late 1870s, the first permanent settlers arrived in the area. After the Utes were removed to reservations in 1881, the Western Slope was opened for mining and cattle ranching. The history of the area is influenced by ranching and mining. In addition, the uranium and vanadium industry influenced the region from 1899 to 1961 (Complete Archeological Service Associates [CASA], 1990).

A Class III cultural resource survey of approximately 260 ac (105 ha) near the UC and NC sites identified a lithic scatter site, an historic site, and two isolated finds in the vicinity of the processing sites. The historic site, a petroglyph panel, is eligible for nomination to the (National Register of Historic Places (NRHP) (CASA, 1987).

Surveys of a 121-ac (49-ha) area that includes the Burro Canyon disposal site identified two sites that fall directly within the proposed disposal site and cannot be avoided during its use (CASA, 1987). These surveys identified projectile points, lithic scatters, and isolated finds (CASA, 1992; 1990). A 1993 site evaluation further characterized the two sites and concluded that 
neither is eligible for nomination to the NRHP (CASA, 1993) and that there would be no effect from the proposed action.

A third site immediately adjacent to the Burro Canyon disposal site is a large and extensive lithic site with possible hearths (CASA, 1992).

Cultural resource field surveys conducted for test pit locations did not identify any cultural sites at the borrow sites (CASA, 1986).

Based on information from the BLM, the DOE contacted the Northern, Southern, and Ute Mountain Ute tribes in February 1994 regarding the possible presence of areas culturally significant to the tribes. The Ute Mountain Ute and Southern Ute Tribes have indicated that their tribes have no areas of cultural concern within the project area. The DOE has not received a response from the Northern Utes as of this writing.

4.8 LAND USE

The UC and NC processing sites, the Burro Canyon disposal site, and the Dolores River and Disappointment Valley borrow sites are in west-central San Miguel County, Colorado, less than $10 \mathrm{mi}(16 \mathrm{~km})$ east of the Colorado-Utah state line. The majority of western San Miguel County is rangeland and woodland used primarily for livestock grazing and timber production. Dry and irrigated croplands comprise 7 and 2 percent of the land, respectively. Mineral exploration, extraction, and milling (primarily for uranium and vanadium) have been an important land use in western San Miguel County. The amount of land devoted to mineral activities fluctuates with market conditions (FBDU, 1981).

Both processing and disposal sites are heavily used during the big game hunting season and for sport hunting of prairie dogs, coyotes, and doves. These areas are known to receive as many as 10,000 hunter days during a single season. Local 4-wheel drive clubs also use both roads as access to surrounding public lands.

\subsubsection{Processing sites}

The UC and NC sites are on land owned by Umetco. Almost all of the surrounding land is administered by the BLM and is used for low-density livestock grazing. Sixty acres ( $24 \mathrm{ha}$ ) of cleared land and irrigated cropland adjacent to the Dolores River between the UC and NC sites, a portion of which may be used for borrow materials, are used for pasture and growing hay. There are some scattered residences in the area. The nearest residence to either processing site is approximately 0.3 air mi $(0.5 \mathrm{~km})$. The unincorporated town of Slick Rock, Colorado, is approximately $1 \mathrm{road} \mathrm{mi}(1.6 \mathrm{~km})$ southeast of the NC site and $1.5 \mathrm{mi}(2.4 \mathrm{~km})$ southeast of the UC site. No oil or gas leases have been issued at the processing sites. 
A gas sweetener plant immediately adjacent to the UC site is not currently in use. In recent years, a volunteer fire station was constructed near the UC tailings pile.

Area recreational use includes rafting on the Dolores River. The river segment between Bradfield Bridge near Cahone, Colorado, and Bedrock, Colorado, is a popular and frequently used portion of the Dolores River. In the past, the Dolores River has been studied and proposed for Wild and Scenic River status, although the status has not been granted (BLM, 1990). River rafting activities occur in the town of Slick Rock generally between the second week of April through the second week of June, or later if the season is good. In 1993, approximately 5500 people participated in 230 launches from Dove Creek and Bradfield then landed in Slick Rock (Ryan, 1993). Memorial Day weekend and the weekends before and after see the most rafting activity. Between the rafters and shuttles for the rafting companies, the town of Slick Rock sometimes accommodates over 100 vehicles daily in the parking area. The rafters shuttle to and from Slick Rock on SH-141.

Slick Rock is also within $5 \mathrm{mi}(8 \mathrm{~km})$ of the Dove Creek and Snaggle Tooth trail ends. Although the BLM does not record the number of users, it is known that these trails are occasionally used by hikers and mountain bikers (Ryan, 1993). The area is seeing an increase in mountain biking activity (Ryan, 1993).

The only commercial complex is a single structure along SH-141 in Slick Rock, which contains a restaurant, liquor store, service station, post office, and sheriff's office. There are numerous mines and gravel pits in the area, although these gravel pits are operated intermittently.

\subsubsection{Disposal site}

The proposed Burro Canyon disposal site area would be a 44-ac (18-ha) area of a $61,515-a c$ (24,895-ha) grazing allotment (Disappointment Creek) managed by the BLM. This vegetation provides approximately 25 animal unit months of forage to livestock at the disposal site. This large allotment is used by approximately 600 cattle for grazing between November 1 and May 31 of each year. Due to the sparse vegetation in the area of the proposed disposal site, only limited grazing occurs there (Werkmeister, 1993).

The proposed Burro Canyon disposal site area is covered by portions of six mining claims. The proposed haul road alignment from the highway to the disposal site is covered by portions of five other claims.

\subsubsection{Borrow sites}

The proposed Dolores River borrow site covers approximately 25 ac (10 ha) and is on private land, in pasture and desert-shrub habitat adjacent to the Dolores River between the processing sites. The land uses at and around the Dolores River borrow site are the same as those described for the UC and NC sites. 
The proposed Disappointment Valley borrow site covers approximately 65 ac (26 ha) of land administered by the BLM. The land immediately west of the borrow site is privately owned; land on all other sides of the site is administered by the BLM. SH-141 is immediately south of the site, and the private land west of the site contains a dirt landing strip and a natural gas pipeline that runs northeast-southwest and connects with the gas sweetener plant adjacent to the UC tailings site (Flinn, 1985). Two 40-ac (16-ha) parcels just outside the borrow site to the north and southeast have been withdrawn by the BLM for public water reserves (Bulinski, 1985).

The land at and around the borrow site is within the Disappointment Creek grazing allotment and is used for low-density livestock grazing. This vegetation provides approximately 10 animal unit months at the borrow area site 65 acres [26 ha]). There are no unpatented mining claims at the borrow site, although the western part of this parcel (Lots 9-14) lies within an oil and gas lease (Bulinski, 1994).

None of the potentially disturbed areas contains critical areas of environmental concern, wild and scenic rivers, or prime or unique farmlands. Under the present resource management plan, the main emphasis for these areas is livestock management (Bulinski, 1993; Alexander, 1993).

\subsection{SOCIOECONOMIC CHARACTERISTICS}

The UC and NC processing sites, the Burro Canyon disposal site, and the Dolores River and Disappointment Valley borrow sites are in San Miguel County, in the sparsely populated southwestern corner of Colorado, less than $10 \mathrm{mi}$ $(16 \mathrm{~km})$ east of the Utah-Colorado state line. The town of Slick Rock, which consists of a combination post office/restaurant/general store, is $1.5 \mathrm{road} \mathrm{mi}$ $(2.4 \mathrm{~km})$ southeast of the UC site and $1 \mathrm{mi}(1.6 \mathrm{~km})$ southeast of the NC site. No one is currently living at or close to (within $0.25 \mathrm{mi}[0.40 \mathrm{~km}]$ ) the UC or NC sites. About 10 people, including residents in two trailers adjacent to the post office, live within $10 \mathrm{mi}(16 \mathrm{~km})$ of the UC and NC sites. There are no schools in the town of Slick Rock.

The 1993 population of San Miguel County was estimated by the Colorado Division of Local Affairs to be at 4314 people; growth is anticipated to occur at around 2 percent per year until the year 2000, when the population of the county is projected to reach 5300 people. January 1994 employment statistics for San Miguel County showed a labor force of 3892, 3716 of whom were employed and 176 of whom were unemployed. This represents a 4.5 percent unemployment rate (Garcia, 1994). The 1990 unemployment rate for Colorado was 5.7 percent (DOC, 1991 a).

Dryland farming, ranching, and uranium mining have occurred historically throughout the western portions of San Miguel, Dolores, Montezuma, and Montrose counties and in the eastern portion of San Juan County in Utah. The more mountainous eastern portions of San Miguel, Montezuma, and Montrose 
counties have different employment bases, although ranching and farming have also provided a consistent source of livelihood in unincorporated areas.

In 1990, San Miguel County had 2635 housing units, with 1489 of these units occupied. Homeowner vacancy rates were 2.8 percent; rental unit vacancy rates were 6.5 percent. These rates were below the state's vacancy rates of 3.3 percent for homeowner units and 11.4 percent for rental units, reflecting a tighter housing market for both types of units. In the Gladel subdivision census of San Miguel County that includes Slick Rock and the western portions of the county, there were 79 housing units: 18 units were for seasonal, recreational, or occasional use; 49 units were occupied ( 34 of them by the owners); and 30 units were vacant (DOC, 1991b; 1991c).

Emergency medical treatment for the Slick Rock area is under jurisdiction of the San Miguel County Sheriff's Department. The closest medical clinics are in Dove Creek, Naturita, and Norwood. As necessary, the Dolores County Sheriff's Department assists with medical emergencies until the San Miguel County Sheriff's Department is able to provide assistance. Air evacuation to Grand Junction, the closest city of size, is also available. Dolores County and Montezuma County, south of the Slick Rock processing sites, would be expected to provide commercial goods and services for the project.

\subsection{TRANSPORTATION}

Only access directly to the processing sites and disposal site would be restricted from public access.

Remedial action workers would access the tailings piles and all borrow sites by use of SH-141. In the vicinity of Slick Rock, this is a paved, secondary, twolane highway rated at level of service A. This level of service means that SH141 could safely carry between 4000 and 6000 vehicles per day. At Slick Rock, the 1988 average daily traffic was recorded at 190 vehicles of all kinds. Peak hourly traffic is estimated at 24 vehicles (Tenney, 1990).

Remedial action traffic would exit northwest from SH-141 onto CR-S8. This paved, two-lane road would provide direct access to the UC and NC tailings piles and Dolores River borrow site. Existing traffic is minimal; an estimated five to six vehicles per day use CR-S8. The pavement is considered in adequate condition for current level of use (Horner, 1986).

Tailings from the NC site would be moved approximately $4 \mathrm{mi}(6.4 \mathrm{~km})$ to the Burro Canyon site, south on CR-10R, east on SH-141, and north on CR-T11 to the disposal site. Tailings from the UC site would be moved approximately $5 \mathrm{mi}$ $(8 \mathrm{~km})$ to the Burro Canyon site, down CR-S8, east on SH-141, and north on CR-T11 to the disposal site.

Daily travel on SH-666 and -141 would be expected for commuting workers. 


\subsection{ENVIRONMENTAL IMPACTS}

The environmental impacts of the proposed remedial action are discussed in this section. The following impacts are based on a 19-month construction schedule, with one 5-month winter shutdown for weather reasons.

\section{$5.1 \quad$ RADIATION}

The proposed action will have a long-term positive impact because the radiologically-contaminated tailings will be relocated and stabilized. Thus, the UC and NC sites would comply with the requirements of 40 CFR \$192.11 that state "the concentration of radium-226 in land averaged over any area of 100 square meters shall not exceed the background level by more than (1) $5 \mathrm{pCi} / \mathrm{g}$, averaged over the first $15 \mathrm{~cm}$ of soil below the surface, and (2) $15 \mathrm{pCi} / \mathrm{g}$, averaged over $15 \mathrm{~cm}$ thick lays of soil more than $15 \mathrm{~cm}$ below the surface" 140 CFR §192.12). Other UMTRA Project sites have shown that completed remedial actions reduce concentrations of radium-226 below those required by the standards.

The principal pathways for human exposure to radiological hazards during remedial action include the inhalation of radon decay products and airborne radioactive particulate matter; direct exposure to gamma radiation; ingestion of ground water and surface water contaminated with radioactive materials; and ingestion of food products produced in areas contaminated by tailings. For the calculation of health effects, only those pathways resulting in the largest radiological doses were considered in detail; these include the inhalation of radon decay products and direct exposure to gamma radiation.

Excess health effects are defined as the number of fatal cancers estimated to occur in a population exposed to radioactive contaminants associated with the processing and disposal sites and the remedial action activities. To interpret excess health effects from exposure to cancer-causing substances in perspective, an individual in the United States has a 16 percent lifetime chance of developing a fatal cancer, or one chance in six, due to all other causes in society.

Since radon decay products are the predominant cause of excess health effects in the general public from the proposed remedial action, the methodology used to analyze their health effects is summarized below:

- Characterization data from the processing site are analyzed to delineate the magnitude and limits of the processing site contamination to be excavated, hauled, and stabilized.

- Radon diffusion parameters are measured for contaminated soil and tailings. 
- The surface radon flux is calculated for a given area and construction scenario using these input parameters and a DOE/NRC-approved radon diffusion computer model, RAECOM, for multilayered media.

- Radon concentrations at selected off-site receptor locations are calculated using local meteorological parameters and standard atmospheric dispersion models.

- Outdoor and indoor radon decay product concentrations are estimated assuming 70 percent plate-out of radon decay products formed during transport from source to receptor location, and a 50 percent indoor equilibrium between calculated receptor radon concentrations and the decay products. It is assumed that people spend 100 percent of their time at home -25 percent outdoors and 75 percent indoors.

- Excess health effects due to this scenario were calculated using a risk factor of 0.00035 excess health effects (fatal cancers) per person-working level month. A working level month is defined as 170 hours of continuous exposure to an atmosphere containing $100 \mathrm{pCi} / \mathrm{L}$ radon in equilibrium with its short-lived radon progeny.

Currently, a radon flux is emanating from the unstable tailings piles and contaminated areas. Consequently, the general public has the potential of being exposed to the resulting radon decay products. The general public is not exposed to gamma radiation from the contaminated materials because no residences are located close enough to the processing sites to be affected by direct radiation; however, there are no effective barriers to prevent the continued dispersion and unauthorized removal of tailings, which could increase the public's exposure to radon decay products and gamma radiation.

During implementation of the proposed action, the general population's exposure from all radiological pathways would decrease as the contaminated materials are excavated from the processing sites and transported to the Burro Canyon disposal cell. Remedial action workers' exposure to contaminated material during remediation would be minimized by adherence to health and safety plans and procedures and by operational and institutional control measures. These include wetting the work area or temporarily stopping work to keep airborne radioactive particulate matter concentrations below harmful levels.

During remediation, the radon flux at the disposal site would increase from background levels to a maximum value when all contaminated materials have been excavated and stabilized in the disposal cell. The radon flux would linearly decrease to or below the design value $\left(20 \mathrm{pCi} / \mathrm{m}^{2} \mathrm{~s}\right)$ as the radon barrier and frost protection layers are placed.

Population exposure from material transport during remediation is considered negligible because the contaminated material in the trucks would be covered with a tarp or treated with a special surfactant to prevent atmospheric dispersion of the material; gamma exposure would be attenuated by the truck 
body and material being hauled and limited to the transit time to the disposal site; and radon emanated during truck transport would be significantly diluted by the ambient air before reaching members of the general public.

The transportation methods are designed to prevent spillage of contaminated materials on roadways. Any tailings spillage on roadways would be immediately cleaned up and therefore would produce only a potential short-term exposure to persons nearby. Contractors working for the DOE would be required to establish and implement procedures for responding to and cleaning up spills.

The only transportation spill that could not be cleaned up readily would be one occurring as a truck crossed a perennial stream or flowing ephemeral drainage. If such a spill occurred, the concentration of radioactive elements and metals would be diluted rapidly by the flowing water. Emergency response plans would immediately be implemented to ensure that health effects would be negligible.

Any material spilled in wetlands would be promptly recovered. Efforts would be implemented to either rehabilitate areas disturbed by the cleanup process or, in the event the impacted wetlands were adversely affected, to obtain regulatory approval for the acquisition of replacement areas.

After completion of the remedial action, the radon release at the disposal site would not exceed the limits allowed by the EPA standards (EPA, 1990). Radon flux measurements would verify that the $20-\mathrm{pCi} / \mathrm{m}^{2} \mathrm{~s}$ standard for the disposal cell is met according to 40 CFR Part 61, National Emissions Standards for Hazardous Air Pollutants (EPA, 1990). If the $20-\mathrm{pCi} / \mathrm{m}^{2} \mathrm{~s}$ standard is not met, radon concentrations at the disposal site boundary would be measured to demonstrate that they do not exceed $0.5 \mathrm{pCi} / \mathrm{L}$ above local background concentrations. Similar measurements of the disposal cell surface radon flux and boundary radon concentrations at complete UMTRA Project sites were indistinguishable from corresponding background measurements. Surface gamma exposure rates from the disposal material would essentially be at background levels.

During remedial action activity, an estimated $4.0 \times 10^{-4}$ excess health effects in the general population would occur due to exposure to radon decay products. Zero excess health effects are estimated to occur to the general public from exposure to gamma radiation originating from the disposal site's contaminated material. The excess health effects in the remedial action worker population resulting from exposure to radon decay products are estimated to be $9.2 \times 10^{-4}$, whereas $5.4 \times 10^{-3}$ excess health effects are estimated to occur in the remedial action worker population due to exposure to gamma radiation.

The total estimated excess health effects (radon decay products and gamma exposure) for the general public during remedial action would be 0.00044 . This compares to the estimated 0.00012 excess health effects if there were no remedial action for an equivalent period of time. 
The estimated short-term excess health effects for the no action alternative are less than those of the proposed action; however, the no action alternative becomes undesirable as the time following remedial action increases. This occurs because under the no action alternative, the general public would continue to be exposed to radiation from the contaminated materials for an indefinite period of time. For example, assuming constant population and no dispersion of the tailings, 0.00025 excess health effects could be estimated to occur in 5 years under the no action alternative. This compares with 0.0000002 excess health effects occurring in the 5 years following the proposed action. A summary of the calculated short-term excess health effects to the public and workers from the proposed remedial action and the no action alternative is provided in Table 5.1.

Table 5.1 Excess short-term health effects for the general public and remedial action workers $^{a, b}$

\begin{tabular}{cccc}
\hline Exposed group & $\begin{array}{c}\text { Radon decay } \\
\text { products exposure } \\
\left(\times 10^{-4}\right)\end{array}$ & $\begin{array}{c}\text { Gamma exposure } \\
\left(\times 10^{-4}\right)\end{array}$ & $\begin{array}{c}\text { Total excess } \\
\text { health effects } \\
\left(\times 10^{-4}\right)\end{array}$ \\
\hline $\begin{array}{c}\text { General public } \\
\begin{array}{c}\text { Proposed } \\
\text { action }\end{array}\end{array}$ & 4.4 & 0 & 4.4 \\
$\begin{array}{c}\text { No action } \\
\begin{array}{c}\text { Remedial action workers } \\
\text { Proposed } \\
\text { action }\end{array}\end{array}$ & 1.2 & 0 & 1.2 \\
No action & 9.2 & 5.4 & 14.6 \\
\hline
\end{tabular}

an excess health effect of $10^{-4}$ or 0.0001 corresponds to 1 chance in 10,000 of an individual's contracting a fatal cancer per year of exposure. The excess health effects for the general public are based on a population of 10 persons within $10 \mathrm{mi}(16 \mathrm{~km})$ of the processing and disposal sites. The excess health effects for no action are for a 24 -month period to allow a direct comparison with the excess health effects due to 24 months of remedial action. This calculation assumed a 24-month remedial action period and one 5-month winter shutdown. The excess health effects for no action do not include the health effects due to no action at the off-site vicinity properties.

bThe excess health effects from airborne radioactive particulates were not calculated. Previous calculations of these health effects have shown them to be orders of magnitude less than those from radon decay products and gamma radiation.

\section{$5.2 \quad$ MINERAL RESOURCES AND SOILS}

The proposed action would result in land disturbance and relocation of local borrow materials, such as gravel and rock. Borrow materials exist in large 
quantities in the Slick Rock and Disappointment Valley areas. The proposed action would not have an impact on other mineral resources in the area. The UC and NC processing sites, Burro Canyon disposal site, and borrow sites are underlain by geologic formations containing noncommercial concentrations of minerals at current market values.

Remedial action activities at Burro Canyon would result in the temporary disturbance of soils on 178 ac (72 ha). These impacts would result from surface disturbances caused by disposal cell excavation, construction and upgrading of access roads, and construction of staging and stockpiling areas. Soil from the disposal cell excavation would be used as a frost barrier. Any remaining soils would be stockpiled and left on the disposal site. Soil compacted as a result of remedial action around the disposal cell would be loosened up and revegetated.

Soil on 125 ac (51 ha) would be disturbed at the UC and NC sites, 92 ac ( $37 \mathrm{ha}$ ) at the UC site, and 33 ac (13 ha) at the NC site. Sixty-seven ac ( $27 \mathrm{ha}$ ) of soil from the UC and NC sites is contaminated and would be permanently placed in the disposal cell. The soil on the remaining acreage would be redistributed but not removed. All excavated areas would be backfilled to match adjacent grades, recontoured where necessary, and revegetated.

Approximately 25 ac (10 ha) may be disturbed at the Dolores River borrow site to obtain $72,700 \mathrm{yd}^{3}\left(55,600 \mathrm{~m}^{3}\right)$ of rock and gravel. The topsoil would be stockpiled and used for restoration of the borrow site. A total of $68,200 \mathrm{yd}^{3}$ $\left(52,100 \mathrm{~m}^{3}\right)$ of soil covering approximately 65 ac (26 ha) may be excavated from the Disappointment Valley borrow site for radon/infiltration barrier material. The topsoil at this borrow site would be stockpiled for use during borrow site restoration. The excavated areas would be backfilled to match adjacent grades, recontoured where necessary, and revegetated.

\subsection{GROUND WATER}

\subsubsection{Processing sites}

The proposed action would have a positive impact on ground water below the processing site because it would remove the source of contamination. In compliance with 40 CFR Part 192, Subpart $B$, the residual contamination in the ground water at the processing sites would be addressed during the UMTRA Ground Water Project. Following removal of the contaminated materials, the aquifer would continue to naturally flush itself of contaminants. The rate of this flushing depends on the rate and direction (horizontal and vertical) of ground water movement, the mobility of specific contaminants within the aquifer, and the effects of buffering and rates of attenuation. More mobile contaminants, such as sulfate and uranium, would move at approximately the same rate as ground water and would be discharged to the Dolores River in a period of a few years to decades, depending on ground water velocities. 


\subsubsection{Disposal site}

The design of the disposal cell would reduce impacts on ground water quality. The DOE has assessed the performance of the designed disposal system and has shown that the disposal cell would minimize and control the release of hazardous constituents to ground water and surface water, as well as radon emanations to the atmosphere, to the extent necessary to protect human health and the environment.

The proposed ground water protection strategy for the Burro Canyon site is based on the application of supplemental standards. Ground water is Class III (limited use) in the uppermost aquifer (upper sandstone unit of the Burro Canyon Formation) because of low yield (less than $150 \mathrm{gpd}\left[6.6 \times 10^{-3} \mathrm{~L} / \mathrm{s}\right]$ ). The DOE has determined that proposing concentration limits and monitoring a point of compliance (POC) at the Burro Canyon disposal site would not further protect human health and the environment because of this low yield and because the uppermost aquifer is not a current or potential source of water. Ground water monitoring would not be effective at the Burro Canyon disposal site and is therefore not proposed because insufficient yield in the uppermost aquifer will preclude its future use. Instead of ground water monitoring, the DOE would conduct long-term surveillance monitoring of the cell. These visual inspections would include looking for physical evidence of mineralization, phreatophyte vegetation, and the presence of saturated zones at sandstone outcrops.

The proposed remedial action design features, in conjunction with favorable hydrogeological and geochemical conditions, would ensure protection of human health and the environment. There are no known registered wells or private water users within the uppermost aquifer (upper sandstone unit of the Burro Canyon Formation) in a $2-\mathrm{mi}(3-\mathrm{km})$ radius of the Burro Canyon disposal site. Furthermore, the middle sandstone unit is protected by hydrogeologic isolation provided by the mudstone units and upward vertical gradients. Low-tomoderate hydraulic conductivities have been measured in the Burro Canyon sandstone units, ranging from $10^{-5}$ to $10^{-7} \mathrm{~cm} / \mathrm{s}$. The confined potentiometric conditions in the middle and lower sandstone units of the Burro Canyon Formation create significant upward hydraulic gradients that would prevent tailings seepage from moving into the middle sandstone unit. The potentiometric surface lies approximately $42 \mathrm{ft}(13 \mathrm{~m})$ above the top of the middle sandstone unit.

\subsection{SURFACE WATER}

The remedial action would be conducted to protect surface water resources. Excavation of contaminated materials at the UC and NC sites would result in surface disturbance from the disturbed areas, including the floodplain. Also, contaminated wastewater would be generated by activities such as equipment washing. The remedial action design provides for construction of drainage and erosion controls, including wastewater retention ponds, to prevent the discharge of contaminated water from the sites. Silt fences or berms would be constructed at the NC site to protect the river from exposure to excavated 
materials. No silt fences would be required at the UC site. Silt fences may also be required at the Burro Canyon site to contain stockpiled material. These control measures would be constructed according to applicable regulations. The contaminated water would be retained for evaporation or for dust control on the tailings piles; sediments from the ponds would be consolidated with the tailings during the final reshaping of the Burro Canyon disposal cell. Following remedial action, all disturbed areas would be recontoured to promote drainage and would be revegetated. Excavation at the NC site would be scheduled for the dry summer months to reduce the impact of runoff caused by precipitation.

Approximately 28 and 13 ac (11 and 5.3 ha) at the UC and NC sites, respectively, would be disturbed within the 100-year floodplain. After the remedial action, the disturbed areas would be backfilled with clean fill material to approximate the original 100-year floodplain. However, the man-made ground elevations of the tailings pile at the UC site would not be reestablished, which would increase the area of the 100-year floodplain at the site by approximately 7 ac ( $3 \mathrm{ha}$ ). Remedial action at the NC site would not increase the size of the 100-year floodplain.

Appropriate drainage and erosion controls would be used at the disposal and borrow sites to minimize or prevent erosion and any corresponding surface water and floodplain impacts. DOE would comply with all applicable Colorado storm water regulations. After remedial action, disturbed areas would be graded to promote drainage and would be revegetated.

Erosion control features incorporated into the disposal cell would prevent excessive rainfall from damaging the cell. These include limiting the topslope of the cell to a 2 to 4 percent slope to promote drainage from the top of the cell at low velocities, and placing a rock erosion protection barrier on the topslopes and sideslopes of the cell to resist the erosive forces of severe rainfall events such as a PMP.

Approximately 150 ac-ft $\left(185,000 \mathrm{~m}^{3}\right)$ of water would be needed for the remedial action for decontamination and dust suppression. Water rights would be secured prior to water use. Water from the river would be used only when water levels are high enough to ensure that adequate flow remained to support fish and wildlife dependent on the river.

\subsection{AIR QUALITY}

Soil excavation, loading tailings into the trucks, truck traffic on dirt roads and tailings piles, and unloading the tailings would temporarily impact air quality. An air pollution emissions notice and emission permit would be obtained from the state of Colorado before remedial action began. This permit would require implementation of a dust control plan to include measures such as covering haul trucks, treating haul roads, limiting speeds on unpaved haul roads, and stopping work during windy periods. A monitoring plan to ensure that air quality standards are not exceeded would be developed by the RAC and must be 
approved by the state of Colorado and San Miguel County before any grounddisturbing activities are initiated.

Control measures would be implemented, including wetting the work area or temporarily stopping work to keep airborne radioactive particulate matter concentrations below harmful levels. To reduce dust generation during the hauling of tailings, dirt roads would be regularly sprayed with water or a chemical dust suppressant. All work would be stopped if dust emissions exceeded state standards; air quality monitoring stations would be used to assure compliance with these specifications.

\subsection{FLORA AND FAUNA}

Flora and fauna would be directly and indirectly affected by remedial action. Direct impacts would include the loss of habitat, loss of less mobile wildife species, and displacement of other species. Indirect impacts would arise from increased fugitive dust, noise, and human activity levels. The duration of the direct impacts would depend on the level and effectiveness of restoration efforts, while most indirect impacts would be short-term (for the life of the Project or less) at the UC and NC sites.

Impacts to flora and fauna were determined by assuming that the remedial action would result in clearing or disturbing an estimated 393 ac (159 ha). Table 5.2 lists plant community types that may be affected by remedial action activities. The majority of the disturbance would occur in the desertgrassland plant community, although the most productive and diverse wildlife habitat that would be impacted is the riparian habitat along the Dolores River. This habitat contains wildlife species found only in riparian areas and is also important to upland wildlife species. The riparian habitat at the UC and NC sites is a diverse mosaic of types. The upper riparian shrub type contains the largest impacted riparian area. The upper riparian shrub and riparian shrub types have the greatest diversity in habitat structure and wildlife use. More details regarding riparian plant communities are provided in Attachment 2 of this EA, Floodplain/Wetlands Assessment.

Important concentration areas for game species, such as critical deer winter range, do not occur in the areas to be impacted along the Dolores River, although mule deer use the riparian zone along the river. The desert bighorn sheep uses the riparian zone along the Dolores River and the upland plant communities near the Burro Canyon site. Remedial action activities would likely have little impact on this species, given its wide range and the large amount of available habitat elsewhere in the area. However, some sheep may be killed by trucks hauling the tailings from the river to the Burro Canyon disposal cell. Drivers would be alerted and speed limits would be imposed in high risk areas if necessary. It may be necessary to direct desert bighorn sheep to areas where visibility is increased and to draw the sheep away from the work zones. Off-site habitat improvement, including water development, would also be implemented, if necessary. The final mitigation plan, if any, would be determined by the DOE in consultation with the Colorado Division of Wildlife and the BLM. Mule deer 
Table 5.2 Plant community types potentially disturbed during the remedial action at the Slick Rock UMTRA sites near Slick Rock, Colorado

\begin{tabular}{|c|c|c|c|c|c|c|c|}
\hline \multirow[b]{3}{*}{ Work area } & \multicolumn{7}{|c|}{ Plant community type (ac) (ha) } \\
\hline & \multirow[b]{2}{*}{ Desert shrub } & \multirow[b]{2}{*}{$\begin{array}{c}\text { Desert } \\
\text { grassland }\end{array}$} & \multirow{2}{*}{$\begin{array}{c}\text { Early } \\
\text { successional } \\
\text { (disturbed } \\
\text { areas) } \\
\end{array}$} & \multicolumn{3}{|c|}{ Riparian } & \multirow[b]{2}{*}{ Total } \\
\hline & & & & $\begin{array}{c}\text { Dense } \\
\text { riparian } \\
\text { shrub }\end{array}$ & $\begin{array}{l}\text { Upper } \\
\text { riparian } \\
\text { shrub } \\
\end{array}$ & $\begin{array}{c}\text { Upper } \\
\text { riparian } \\
\text { grassland } \\
\end{array}$ & \\
\hline UC tailings site & $\begin{array}{l}56.7 \\
(22.9)\end{array}$ & 0.0 & $\begin{array}{l}14.0 \\
(5.6)\end{array}$ & $\begin{array}{c}4.6 \\
(1.9)\end{array}$ & $\begin{array}{l}10.2 \\
(4.1)\end{array}$ & $\begin{array}{c}6.5 \\
(2.6)\end{array}$ & $\begin{array}{c}92.0 \\
(37.2)\end{array}$ \\
\hline NC tailings site & $\begin{array}{l}12.6 \\
(5.1)\end{array}$ & 0.0 & 0.0 & $\begin{array}{c}5.4 \\
(2.2)\end{array}$ & $\begin{array}{l}15.0 \\
(6.1)\end{array}$ & 0.0 & $\begin{array}{c}33.0 \\
(13.4)\end{array}$ \\
\hline Burro Canyon disposal site & 0.0 & $\begin{array}{c}178 \\
(72)\end{array}$ & 0.0 & 0.0 & 0.0 & 0.0 & $\begin{array}{l}178 \\
(72)\end{array}$ \\
\hline $\begin{array}{l}\text { Disappointment Valley } \\
\text { borrow site }\end{array}$ & $\begin{array}{c}65.0 \\
(26.3)\end{array}$ & 0.0 & 0.0 & 0.0 & 0.0 & 0.0 & $\begin{array}{c}65.0 \\
(26.3)\end{array}$ \\
\hline Dolores River borrow site & 0.0 & $\begin{array}{l}25.0 \\
(10.1)\end{array}$ & 0.0 & 0.0 & 0.0 & 0.0 & $\begin{array}{c}25.0 \\
(10.1)\end{array}$ \\
\hline Total & $\begin{array}{r}134.3 \\
(54.4) \\
\end{array}$ & $\begin{array}{l}203 \\
(82.1) \\
\end{array}$ & $\begin{array}{l}14 \\
(5.7) \\
\end{array}$ & $\begin{array}{l}10.0 \\
14.01 \\
\end{array}$ & $\begin{array}{c}25.2 \\
(10.2) \\
\end{array}$ & $\begin{array}{c}6.5 \\
(2.6) \\
\end{array}$ & $\begin{array}{r}393 \\
(159) \\
\end{array}$ \\
\hline
\end{tabular}


and elk winter concentration areas occur in the area of the Burro Canyon disposal site and Disappointment Valley borrow site; project-related impacts on these two species would be minimal, because no remedial action activities would take place in the winter (December through mid-April).

T\&E and federal candidate species may occasionally occur at all of the Slick Rock sites. However, because the black-footed ferret was not observed during surveys at the Burro Canyon disposal site and Disappointment Valley borrow site, remedial action would be expected to result in no direct effect on these species. There are no wintering eagle concentration areas along the section of river valley to be impacted, although occasional wintering birds occur along the river and in the disposal site area. Remedial action would not affect these birds, because the Project would be shut down during the winter (December through mid-April). Further, none of the cottonwood stands in the area of the tailings sites would be affected. The peregrine falcons whose two aeries are $8 \mathrm{mi}$ $(10 \mathrm{~km})$ from the construction zone would not be impacted due to the relatively long distance and availability of other feeding areas. Listed fish species would not be directly affected since these species do not occur in the Dolores River. However, depletion of water from the upper Colorado River Basin (which includes water needed for remedial action from the Dolores River) may constitute basin-wide cumulative effects on these species and their critical habitat. Formal consultation with the FWS was initiated to mitigate potential cumulative impacts that withdrawal of water would have on listed fish species and their critical habitat. Water removed from the Dolores River would require a one-time contribution to the FWS. Approximately $150 \mathrm{ac}-\mathrm{ft}\left(185,000 \mathrm{~m}^{3}\right)$ of water would be required during the 19-month remedial action period and the average annual usage $\left(75 \mathrm{ac}-\mathrm{ft}\left[92,000 \mathrm{~m}^{3}\right]\right)$ would be subject to an annual $\$ 11.98$ per ac-ft contribution. The FWS has concurred with this finding in their Biological Opinion (see Appendix B of Attachment 1). The water depletion fee would be paid to the FWS prior to the beginning of remedial action.

The southwestern willow flycatcher was not observed at or near the processing sites during the 1990, 1991, and 1994 surveys, although appropriate nesting habitat does occur at these sites. A survey for this species will be conducted in 1995, prior to the initiation of remedial action, to assess its current status near the processing sites. If the species is determined to nest at or near the construction zones, a mitigation plan to prevent or reduce potential impacts would be prepared in consultation with the FWS.

The river otter occurs occasionally in the river near the two processing sites, but impacts on this species would be minimal because no remedial activities would take place in the river. The white-faced ibis and black tern do not occur near the sites and would not be impacted.

\subsection{HISTORIC AND CULTURAL RESOURCES}

No adverse impacts to cultural resources are expected due to protective measures implemented during remedial action. Two lithic sites occurring at the proposed Burro Canyon disposal cell site were identified and tested to determine 
significance and eligibility for nomination to the NRHP. The field work was conducted on federal land managed by the San Juan Resource Area BLM, under authorization of a Colorado BLM Cultural Resource Use Permit and Project Authorization. Both sites contain large amounts of flaked lithic materials. As it was determined that neither site contained data important to interpreting the prehistoric occupation of the area, neither site is considered significant or eligible for nomination to the NRHP. Therefore, no mitigation measures are deemed necessary (CASA, 1993).

Two sites of cultural interest near the Slick Rock sites could potentially be impacted by remedial actions: a petroglyph panel near the UC site and the large and extensive lithic site near the Burro Canyon site. Uncontrolled remedial activities could harm or destroy the sites. The petroglyph panel near the UC site, eligible for nomination to the NRHP, could be degraded by dust and rocks thrown up from the roads and from exhaust fumes. During remedial action, the panel would be protected by a SHPO-approved method; the panel could be protected, for instance, by a protective barrier such as a chain link fence and plywood panels or a tarp.

The disposal cell borders a large and extensive lithic site. Uncontrolled remedial actions could destroy the site by allowing heavy equipment to run over artifacts. The boundary between the final disposal cell and the lithic site was established in November 1993 after a walkthrough of the area with the RAC, UMTRA Project personnel, and the BLM. It was agreed that the lithic site would be permanently fenced off and avoided during remedial action.

If an unexpected discovery of cultural resources were made during the proposed action, work would stop in the area of discovery and the appropriate state and federal agencies would be contacted to inspect and evaluate the finding.

\section{$5.8 \quad$ LAND USE}

\subsubsection{Processing sites}

The proposed action would have little effect on current land uses at the UC and NC processing sites. The volunteer fire station on the UC site would be surveyed by the DOE for radiological contamination. If contaminated, it would be decontaminated, if possible, and left in place. If it could not be decontaminated, it would be demolished and the debris disposed of in the cell. If the fire station is not found to be contaminated, it would be left in place, undisturbed.

Indirect impacts include visual impacts and access restrictions. Although recreationists would be able to observe remedial actions from the river as they passed by the processing sites, the sites would be restricted from access to all persons except those associated with the remedial action. 


\subsubsection{Disposal site}

During remedial action, approximately 178 ac ( 72 ha) would be temporarily removed from use. This area would be temporarily fenced and unavailable for grazing, hunting, or any recreational activities. Approximately 134 ac (54 ha) would be restored after remedial action and returned to the BLM for unrestricted use.

The final restricted disposal site area would cover approximately 44 ac (18 ha). This area would be under the direct control of the DOE and would be restricted from development. The current November-to-May access to grazing cattle would be halted. Approximately 600 cattle graze in a 62,000-ac (25,000-ha) BLM area, including the 44 ac (18 ha) proposed to be restricted from further use (Werkmeister, 1993). Thirty-five animal months of livestock grazing would be lost for up to 10 years, depending on the length of the reclamation process. The value of this temporary forage loss could be determined from the average amount the permittee would have to pay for replacement forage. The BLM has calculated permanent loss in forage as the equivalent of 8 animal unit months. The DOE would be required to compensate the current land users for any losses incurred by the proposed remedial action or develop suitable mitigation, such as the installation of water wells in underutilized areas.

The proposed action would not affect future recovery or development of mineral resources beneath the disposal site. The disposal site is on land administered by the BLM and has six mineral claims. Because of the depth of the ore, the disposal site's withdrawal from the BLM to the DOE would not preclude exploration and development of the deposits. Also, calculations indicate that mines at this depth would have no impact on the long-term stability of the cell (TAC, 1990b). Public Law 95-604 requires that the mineral rights for the disposal site be transferred to the federal government along with the disposal site. It also authorizes the Secretary of the Interior, with the concurrence of the Secretary of Energy and the NRC, to dispose "of any subsurface mineral rights by sale or lease... if the Secretary of the Interior takes such action as the Commission deems necessary pursuant to the license issued by the Commission to assure that the residual radioactive materials will not be disturbed by reason of any activity carried on following such disposition." Any recovery of mineral resources from beneath the Burro Canyon disposal site would, therefore, be governed by license conditions to prevent any disturbance of the disposal cell.

The BLM would conduct validity examinations of the claims, and the DOE would compensate valid claim holders to the extent required by law.

\subsubsection{Borrow sites}

The removal of materials from the proposed borrow sites would impact current grazing uses. Prior to any ground-disturbing remedial action activities, the DOE would compensate existing users for lost grazing privileges or develop suitable mitigation, such as the installation of water wells in underutilized areas. Approximately 25 ac (10 ha) would be disturbed at the proposed Dolores River 
borrow site in a manner protective of the Dolores River. Approximately 65 ac (26 ha) of materials would be disturbed at the proposed Disappointment Valley borrow site. The removal of borrow materials would be planned and conducted to avoid encroachment on the public water reserve withdrawal area near the Disappointment Valley borrow site.

After completion of the remedial action, all disturbed areas would be reclaimed in accordance with landowner or land administrator (e.g., BLM) requirements. Reclamation would include grading (including filling where necessary) and seeding according to BLM recommendation.

\subsection{SOCIOECONOMICS}

Direct and indirect impacts on employment, housing, community services, or the economy from the proposed action would be minimal because of the remedial action's short duration (19 months, with a 5-month winter shutdown) and the relatively small number of workers needed (approximately 100 to 160). Furthermore, impacts are expected to be distributed among the nearby communities of Slick Rock, Egnar, Cortez, Dove, Norwood, Nucla, Dolores, and the more distant communities of Telluride, Montrose, Durango, and Grand Junction. Consequently, no single community is likely to be significantly affected by the proposed remedial action.

A large influx of permanent workers into the Slick Rock area is not expected. An average work force of approximately 100 workers would be required during the 19 months of remedial action, with a maximum of 160 workers needed during the hauling phase. Labor categories in highest demand would be truck drivers and heavy equipment operators. Experience at other Colorado UMTRA Project sites indicates that 60 to 90 percent of the remedial action workers (estimated as approximately 60 and 90 workers for the proposed Slick Rock remedial action) are hired from within a $60-\mathrm{mi}(97-\mathrm{km})$ commuting distance of a site (DOE, 1993). Remedial action workers would likely commute daily from communities within $60 \mathrm{mi}(97 \mathrm{~km})$; however, commutes of over $100 \mathrm{mi}$ $(161 \mathrm{~km})$ have been necessary at some UMTRA Project sites, including Ambrosia Lake, New Mexico.

Secondary employment may be generated when money spent on the remedial action is respent in the local area and the new expenditures create a demand for new jobs, typically in the services industries. Experience indicates that the average secondary employment multiplier for the Slick Rock area is 1.7 (i.e., for each remedial action job, 0.7 of a new job would be created) (DOE, 1993). However, the relatively short remedial action period and the seasonal nature of the work make any appreciable secondary employment unlikely.

Approximately 24 workers, primarily contractor management personnel, would be expected to commute from Cortez, where they currently reside while working on an UMTRA Project site in Utah. Some workers with specialized skills (e.g., health physicists) may temporarily relocate to Cortez or nearby communities during the two construction seasons, or they may use temporary 
housing such as motels. Workers who temporarily relocate for construction projects such as the Slick Rock remedial action generally do not bring their families with them. This is particularly true for workers with school-age children because of the 5-month winter shutdown during the school season. Workers who might bring families during the construction season would not be likely to have school-age children.

The wages and salaries paid to remedial action workers and the expenditures for equipment, materials, and supplies would have direct, positive impact on the economies of San Miguel, Dolores, and Montezuma Counties. Local economies would also benefit indirectly as the monies from these wages, salaries, and local purchases were recirculated. Direct and indirect expenditure by contracts to the DOE would generate tax revenue for local and state government use.

The estimated cost of the remedial action is $\$ 7.5$ million, which includes labor, equipment purchases and leases, materials, and miscellaneous purchases. Wages and salaries would total approximately $\$ 3.4$ million.

\subsection{TRANSPORTATION}

The remedial action would temporarily affect local transportation systems, particularly during the rafting season. No long-term or permanent impacts would occur. The proposed action would use approximately $15 \mathrm{mi}(24 \mathrm{~km})$ of area roads for transportation of tailings, contaminated soils, and borrow materials. SH-141 between the NC processing site and the proposed Burro Canyon disposal site exits may be upgraded by applying new pavement coating, installing temporary warning traffic signs, and improving line-of-sight at the Burro Canyon turn-off. New signs and as-needed upgrades would also be constructed for the county roads. CR-T11 would be extended to approximately $4200 \mathrm{ft}(1280 \mathrm{~m})$ and would be widened to approximately $32 \mathrm{ft}(10 \mathrm{~m})$. The right-of-way would be widened to $100 \mathrm{ft}(30 \mathrm{~m})$. CR-10R and CR-S9 between the two mill sites would be widened to $32 \mathrm{ft}(10 \mathrm{~m})$, but closed to the public during the remedial action. Surface improvements to county roads would be made with gravel and dirt. Approximately $1500 \mathrm{ft}(457 \mathrm{~m})$ of CR-S 8 within the UC site would be temporarily detoured along an old alignment. During the hauling period, Colorado-certified flag persons would regulate the vehicular traffic during truck transport hours. The roads would be returned to their preconstruction conditions and alignments after remedial action is complete.

An estimated maximum of 280 highway truck trips per day would take place between the processing sites and the disposal cell during the first construction season.

CR-S8 and -T11 would remain open to the public during remedial action. Delays during working hours for road upgrades would be minimized. All roads would be free of delays after work hours and on weekends. However, CR-1OR and CR-S9 would be closed for the duration of the remedial action period as it only provides access to the UC and NC sites. Public access to the construction areas would be prohibited. 
Remedial action construction traffic would increase the amount of traffic during the peak rafting season from mid-April to mid-June. Shuttle vehicles from the rafting companies and private vehicles of rafters travel on $\mathrm{SH}-141$ to and from Slick Rock, especially on Friday, Saturday and Sunday. There is a potential for an increase in traffic accidents due to the increase in vehicles, especially if the haul phase of the remedial action were to coincide with rafting season. Upgrades to the roads, new signs, and strategic placement of trained flag persons would mitigate the potential for impacts of accidents. The DOE would keep BLM apprised of project activity so information can be disseminated to recreational users. The DOE would also notify the local public of project activities.

\section{$5.11 \quad$ NO ACTION}

Under the no action alternative, the general public would continue to be exposed to radon and radon progeny from the existing uranium tailings piles and associated contaminated materials. Under the current conditions, an estimated $5 \times 10^{-5}$ excess health effects would occur each year in the surrounding population. For an individual in the exposed population of 10 people within $10 \mathrm{mi}(16 \mathrm{~km})$ of the processing sites, $5 \times 10^{-5}$ annual excess health effects implies a chance of one in 113,360 of developing a fatal cancer. This does not consider unavoidable wind and water dispersement of contaminated materials and the increased potential for excess health effects.

Population growth and unauthorized removal and use of the tailings could lead to more excess health effects than calculated. Contaminated materials would continue to be exposed to erosion, which would eventually result in the transport of contaminants into the Dolores River. The processing sites and adjacent areas would remain unusable. No mitigation measures would be implemented.

\subsection{POTENTIAL IMPACTS AND MITIGATION MEASURE SUMMARY}

\section{Radiation impacts}

Impact - Remedial action workers could be harmed by exposure to contaminated materials.

Mitigation measure - Remedial action worker's exposure to contaminated material during remediation would be minimized by adherence to health and safety plans and procedures, including DOE Order 5480.11, Radiation Protection for Occupational Workers. Operational and institutional control measures that include wetting the work area or temporarily stopping work during periods of high wind to keep airborne radioactive particulate matter concentrations below harmful levels would also be implemented.

Impact - The public and the environment could be harmed by exposure to contaminated materials. 
Mitigation measure - The public's exposure to contaminated material during remediation would be minimized by adherence to health safety plans and procedures, including DOE Order 5400.5, Radiological Protection of the Public and the Environment.

Mitigation measure - To prevent the spread of contamination while contaminated materials are being transported, all haul trucks would be monitored and decontaminated before entering public roads and would be covered with a tarp or treated with a special surfactant to prevent atmospheric dispersion of the contaminated material.

Mitigation measure - All traveled areas would be monitored regularly for radioactive contaminants. Any tailings spillage on roadways would be immediately cleaned up by trained personnel.

Mitigation measure - Waste water retention ponds will be flagged to discourage incidental bird landing.

\section{Surface water}

Impact - Approximately 150 ac-ft $\left(185,000 \mathrm{~m}^{3}\right)$ of water will be taken from the Dolores River for decontamination and dust suppression over the 19-month remedial action period in amounts protective of fish and wildlife that are dependent on an adequate flow in the river. (The impacts to, and mitigation measures for, endangered fish species in the upper Colorado River Basin and their critical habitat are addressed under flora and fauna.)

Impact - Surface water, including the Dolores River, could be contaminated by materials spilling into the water during remedial action.

Mitigation measure - Silt fences would be constructed at the NC site to protect the river from exposure to excavated materials. Silt fences would not be required at the UC site.

Mitigation measure - Drainage and erosion controls, including wastewater retention ponds, would be constructed to prevent the discharge of contaminated water into the Dolores River.

Mitigation measure - Excavation at the NC site would be scheduled for the dry summer months to reduce the impact caused by precipitation.

Mitigation measure - Appropriate drainage and erosion controls would be used at the disposal and borrow sites to minimize or prevent erosion and corresponding surface water impacts.

Mitigation measure - Disturbed areas would be graded to promote drainage and would be revegetated when remedial action is complete. 


\section{Ground water}

Impact - Ground water beneath and downgradient of the disposal cell could become contaminated.

Mitigation measure - No mitigation measures are planned because of the limited yield (less than $150 \mathrm{gpd}\left[6.6 \times 10^{-3} \mathrm{~L} / \mathrm{s}\right]$ ) of ground water in the uppermost aquifer. There are no known registered wells or private water users within the uppermost aquifer in a 2-mi $(3-\mathrm{km})$ radius of the Burro Canyon disposal site. The DOE has determined that proposed concentration limits and monitoring a POC at the Burro Canyon disposal site would not further protect human health and the environment because of this low yield and because the uppermost aquifer is not a current or potential source of water.

\section{Mineral resources and soils}

Impact - Soil would be disturbed during remedial action at the NC, UC, proposed Burro Canyon, and borrow area sites and the contour of surface at all sites would change.

Mitigation measure - Disturbed areas at the UC, NC, proposed Burro Canyon, and borrow areas would undergo restoration after remedial activities are complete. Excavated areas would be backfilled to match adjacent grades. All graded, excavated, or similarly disturbed soil surfaces would be reseeded.

Impact - A loss of mining claims on the proposed Burro Canyon disposal site would occur.

Mitigation measure - The DOE would compensate valid claim holders to the extent required by law.

\section{Air quality}

Impact - Dust generated during remedial action may contain contaminated materials that could degrade air quality.

Mitigation measure - Operational and institutional control measures would be implemented that include wetting the work area or temporarily stopping work to keep airborne radioactive particulate matter concentrations below harmful levels.

Mitigation measure - To reduce the generation of dust during the hauling of tailings, dirt roads would be sprayed with water regularly.

Mitigation measure - All work would be stopped if dust emissions exceeded state standards. An air quality monitoring station would be used to assure compliance with state guidelines. 


\section{Flora and fauna}

Impact - Clearing of land would result in a temporary loss of the flora and fauna habitat, and fencing the site would result in a permanent loss of access by larger animals to the disposal cell.

Mitigation measure - Although some loss of habitat would occur and cannot be mitigated (i.e., at the disposal cell), the size of the temporarily fenced construction areas would be as small as possible and temporarily disturbed areas would be restored upon completion of remedial action.

Impacts - Bighorn sheep could be accidentally killed on roads by trucks.

Mitigation measure - Speed limits would be imposed where necessary, and truck drivers would be alerted as to the possibility of sheep being on the roads. Other measures, including fencing or off-site habitat improvement and water development may be considered to make areas away from the work zones more attractive to the sheep.

Impact - Endangered fish species in the upper Colorado River Basin and their critical habitat could be adversely affected by the depletion of approximately 150 ac-ft $\left(185,000 \mathrm{~m}^{3}\right)$ of water from the Dolores River over the 19-month remedial action period.

Mitigation measure - The DOE would pay the FWS \$11.98 per acre-foot of water used, based on average annual consumption. The funds would be used to enhance the quality of habitat for threatened and endangered species.

Impact - Mule deer and elk winter concentration populations could be reduced in the area of the Burro Canyon disposal site and the Disappointment Valley borrow site.

Mitigation measure - No remedial action activities would take place in the winter.

Impact - Approximately 41 ac (17 ha) of riparian habitat at the Slick Rock processing sites would be disturbed by the remedial actions, which would temporarily reduce or prohibit wildlife use.

Mitigation measure - It is anticipated that the mitigation of remedial action impacts to the riparian habitat would be included in the mitigation of remedial action impacts to wetlands, as determined in the USACE Section 404 Permit process. DOE would also comply with stipulations provided by BLM.

\section{Historical and cultural resources}

Impact - Dust and rocks from road traffic could degrade the petroglyph panel across from the UC site. 
Mitigation measure - The petroglyph panel would be protected in a manner approved by SHPO, possibly with a chain link fence and plywood panels or tarps.

Impact - Damage to a large and extensive lithic site adjacent to the Burro Canyon disposal cell could occur from running heavy equipment or excavating artifacts.

Mitigation measure - The lithic site has been permanently fenced off and will be avoided during remedial action.

Impact - Undiscovered cultural resources could be damaged during remedial actions.

Mitigation measure - In the event an unexpected discovery of cultural resources is made during the proposed action, work would stop in the area of discovery and the appropriate state and federal agencies would be contacted to inspect and evaluate the finding.

\section{Land use}

Impact - Minor, long-term visual impacts from the disposal cell would occur.

Mitigation measure - The disposal cell would be developed with a partially below grade line-of-sight and covered with local materials that should blend with the local environment.

Impact - Hikers, hunters, rafters, and other recreationists would experience temporary visual impacts during remedial action by construction work occurring in an area visited for its natural beauty and by permanent restricted access to the disposal cell.

Mitigation measure - These impacts are unavoidable under the proposed action and no mitigation measures are suggested.

Impact - The fire station would be surveyed by the DOE to see if it is contaminated. If it is, and it can be decontaminated, it would not be disturbed. If it cannot be decontaminated, it would be dismantled and disposed of in the cell. If it is not contaminated, it would remain undisturbed.

Mitigation measure - The DOE would negotiate with the county to ensure that the services provided by the volunteer fire station are not disrupted during remedial action. Possible solutions would be to move the fire station or build a new one at an alternate location.

Impact - A temporary and permanent loss of grazing forage would occur. Topsoil would be removed and stockpiled for replacement and restoration purposes.

Mitigation measure - The DOE would mitigate any impacts to affected landowners and grazing lessees by negotiating agreements. 
Impact - A loss of mining claims on the proposed Burro Canyon disposal site would occur.

Mitigation measure - The DOE would compensate valid claim holders to the extent required by law.

\section{Socioeconomics}

Impact - Small positive and negative impacts to employment, housing, services, and the economy are expected to be distributed throughout a number of communities. No mitigation measures are planned because the impact to any one community would be minimal.

\section{Transportation}

Impact - Traffic congestion may occur during rafting season.

Mitigation measure - Road improvements would be made to decrease the potential for traffic accidents due to increased traffic. $\mathrm{SH}-141$ between the NC and Burro Canyon exits would be upgraded by applying new pavement coating, installing temporary traffic signs, and improving line-of-sight at the Burro Canyon turn-off. Acceleration and deceleration lanes may also be provided at the Burro Canyon turn-off. New signs and as-needed upgrades will also be constructed for the county roads. CR-T11 would be extended to approximately $4200 \mathrm{ft}(1280 \mathrm{~m})$ and would be widened to approximately $32 \mathrm{ft}(10 \mathrm{~m})$. The right-of-way would be widened to $100 \mathrm{ft}(30 \mathrm{~m})$. CR-10R would be widened to $32 \mathrm{ft}(10 \mathrm{~m})$, but not open to the public during the remedial action. CR-S9 would also be restricted from public use during the remedial action. Surface improvements to CRs would be made with gravel and dirt. During the hauling period, Colorado-certified flag persons would regulate the vehicular traffic during truck transport hours. The roads would be returned to their pre-construction conditions after remedial action is complete.

The DOE would keep BLM apprised of project activity so that information can be disseminated to recreational users.

\section{No action}

Impact - Humans, ground water, and the environment could be exposed to contaminated materials.

Mitigation measure - No mitigation measures would be implemented under the no action alternative. 


\subsection{CONSULTATION AND COORDINATION}

The DOE has informed the local managing entities and the public, through informal meetings, of the proposed action and areas under evaluation. In addition, copies of the draft EA were distributed to members of the public for review and comment. Opportunities for public comment were advertised in local papers and encouraged at public meetings. No public comments were received, however. The following state and federal agencies have been instrumental in providing information on their resources:

- Bureau of Land Management, U.S. Department of the Interior, Montrose District Office, San Juan Resource Area Office.

- Colorado Department of Public Health and Environment.

- Colorado Division of Wildlife, Colorado Department of Natural Resources.

- U.S. Department of the Interior, Fish and Wildlife Service.

- U.S. Army Corps of Engineers, U.S. Department of Defense. 


\subsection{REFERENCES}

Alexander, R., 1993. Bureau of Land Management, Montrose, Colorado, telephone conversation with Sandra Beranich, Jacobs Engineering Group Inc., Environmental Services Department, UPDCC File Location No. 11.2.8, Albuquerque, New Mexico, February 3, 1993.

Banani, A., 1994. MK-Ferguson correspondence dated June 16, 1994. UPDCC File Location No. SRKEA, Albuquerque, New Mexico.

BFEC, 1986. Radiological Characterization of the Slick Rock, Colorado, Uranium Mill Tailings Remedial Action Sites, Bendix Field Engineering Corporation, Grand Junction, Colorado.

BLM (Bureau of Land Management), 1990. Dolores River Corridor Management Plan, U.S. Department of the Interior, Montrose District, Colorado, San Juan Resource Area, Durango, Colorado.

BLM (Bureau of Land Management), 1982. Archaeological Resources in Southwestern Colorado, Cultural Resources Series Number 13, Bureau of Land Management, Denver, Colorado.

Bulinski, K., 1994. Bureau of Land Management, San Juan Resource Area, Durango, Colorado. Information provided in Comments on SRKEA, dated July 7, 1994, UPDCC File No. SRKEA.

Bulinski, K., 1993. Bureau of Land Management, San Juan Resource Area, Durango, Colorado, personal communication to Sandra Beranich, Environmental Services Department, Jacobs Engineering Group Inc., UPDCC File Location No. 11.2.8, Albuquerque, New Mexico, January 22, 1993.

Bulinski, K., 1985. Bureau of Land Management, San Juan Resource Area, Durango, Colorado, personal communication to Sandra Beranich, Environmental Services Department, Jacobs Engineering Group Inc., UPDCC File Location No. 11.2.8, Albuquerque, New Mexico, October 31, 1985.

CASA (Complete Archaeological Service Associates), 1993. "Cultural Resource Significance, Testing, and Evaluation," prepared by CASA, Cortez, Colorado, for Jacobs Engineering Group Inc., Albuquerque, New Mexico.

CASA (Complete Archaeological Service Associates), 1992. "Cultural Resource Inventory, Additional Areas, Burro Canyon Disposal Site," prepared by CASA, Cortez, Colorado, for Jacobs Engineering Group Inc., Albuquerque, New Mexico.

CASA (Complete Archaeological Service Associates), 1990. "Cultural Resource Planning Inventory, Burro Canyon Disposal Site," prepared by CASA, Cortez, Colorado, for Jacobs Engineering Group Inc., Albuquerque, New Mexico. 
CASA (Complete Archaeological Service Associates), 1987. "Cultural Resource Inventory, Slick Rock and Naturita, Colorado," prepared by CASA, Cortez, Colorado, for Jacobs Engineering Group Inc., Albuquerque, New Mexico.

CASA (Complete Archaeological Service Associates), 1986. "Cultural Resource Inventory of Forty-Seven Test Pit Locations, Slick Rock and Naturita, Colorado," prepared by CASA, Cortez, Colorado, for Jacobs Engineering Group Inc., Albuquerque, New Mexico.

CDPHE (Colorado Department of Public Health and Environment), 1986. "Classifications on Numeric Standards for Gunnison and Lower Dolores River Basins," CDH, Water Quality Control Commission, Denver, Colorado.

DOC (U.S. Department of Commerce), 1991a. 1990 Census of Population and Housing: Summary Social, Economic, and Housing Characteristics, Colorado, U.S. Department of Commerce, Economics and Statistics Administration, Bureau of the Census.

DOC (U.S. Department of Commerce), 1991b. 1990 Census of Population and Housing: Summary Population and Housing Characteristics, Colorado, U.S. Department of Commerce, Economics and Statistics Administration, Bureau of the Census.

DOC (U.S. Department of Commerce), 1991c. 1990 Census of Population and Housing: General Housing Characteristics, Colorado, U.S. Department of Commerce, Economics and Statistics Administration, Bureau of the Census.

DOE (U.S. Department of Energy), 1994. Remedial Action Plan and Site Design for Stabilization of the Inactive Uranium Processing Site at Slick Rock, Colorado, preliminary final, DOE/AL/62350-21, prepared by the U.S. Department of Energy, UMTRA Project Office, Albuquerque Operations Office,

DOE (U.S. Department of Energy), 1993. Final Colorado Economic Impact Study on the Uranium Mill Tailings Remedial Action Project in Colorado, UMTRA-DOE/AL400691.0000, DOE UMTRA Project Office, Albuquerque Operations Office, Albuquerque, New Mexico.

DOE (U.S. Department of Energy), 1989. Technical Approach Document, UMTRA-DOE/AL-050425.0002, DOE UMTRA Project Office, Albuquerque Operations Office, Albuquerque, New Mexico.

DOE (U.S. Department of Energy), 1986a. Alternate Site Selection Process for UMTRA Project Sites, UMTRA-DOE/AL-200129.007 R-1, DOE UMTRA Project Office, Albuquerque Operations Office, Albuquerque, New Mexico.

DOE (U.S. Department of Energy), 1986b. Comparative Analysis of Disposal Site Alternatives Report for the UMTRA Project, Slick Rock Site, Located at Slick Rock, Colorado, JEG/UMT-1286-0546, UPDCC File Location No. 11.30.6, Albuquerque, New Mexico. 
EG\&G, 1982. "An Aerial Radiological Survey of Slick Rock, Colorado and Surrounding Area," EG\&G Survey Report EP-U-016, Energy Measurements Group Las Vegas, Nevada.

Ely et al. (R. W. Ely, I. G. Wong, and Ping-Sheng Chang), 1986. "Neotectonics of the Uncompahgre Uplift, Eastern Utah and Western Colorado," in Contributions to Colorado Seismicity and Tectonics, W. P. Rogers, ed., Colorado Geological Survey, pp. 75-92, Denver, Colorado.

EPA (U.S. Environmental Protection Agency), 1990. Title 40 - Protection of the Environment, Part 61.222, United States Government, Washington, D.C., 1990.

FBDU (Ford, Bacon \& Davis Utah, Inc.), 1981. "Engineering Assessment of Inactive Uranium Mill Tailings, Slick Rock Sites, Slick Rock, Colorado," DOE/UMT-0115, FBDU 360-07, UC 70, prepared by FBDU, Salt Lake City, Utah, for the U.S. Department of Energy, UMTRA Project Office, Albuquerque Operations Office, Albuquerque, New Mexico.

Flinn, B., 1985. Bureau of Land Management, San Juan Resource Area Office, Durango, Colorado, personal communication to Sandra Beranich, Jacobs Engineering Group Inc., UPDCC File Location No. 11.2.8, Albuquerque, New Mexico, December 3, 1985.

Garcia, B., 1994. Colorado Department of Labor, Denver, Colorado, personal communication to Malu Gawthrop, Jacobs Engineering Group Inc., UPDCC File Location No. 11.2.8, Albuquerque, New Mexico, March 24, 1994.

Hill, S., 1989. Jacobs Engineering Group Inc., UMTRA Project Manager, letter to Mark Matthews, DOE UMTRA Project Manager, JEGA/UMT/1189-0460, UPDCC File Location No. 11.30.6, November 1989.

Horner, M., 1986. County Road Supervisor, San Miguel County Road and Bridge Department, Telluride, Colorado, personal communication to Sandra Beranich, UPDCC File Location No. 11.2.8, Jacobs Engineering Group Inc., Albuquerque, New Mexico, December 19, 1986.

Hunt, C. B., 1974. National Regions of the United States and Canada, W. H. Freeman and Company, San Francisco, California.

Kirkham, R. M., and W. P. Rogers, 1981. "Earthquake Potential in Colorado, a Preliminary Evaluation," in Colorado Geological Survey Bulletin, No. 43, Denver, Colorado.

McBee, J., 1990. Jacobs Engineering Group Inc., memo to Chris Watson, JEGE/JEG/ 0390-0035, UPDCC File Location No. 11.30.6, Albuquerque, New Mexico, March 9, 1990.

MK-Ferguson, 1993. Correspondence from D. R. Sanders to R. E. Lawrence, UPDCC File Location No. 11.2.8, Albuquerque, New Mexico, September 27, 1993. 
NGDC/NOAA (National Geophysical Data Center/National Oceanic and Atmospheric Administration), 1989. "Dry Flats site, Colorado: Epicentral Compilation for Magnitude $M=4$ and $I=1$," Boulder, Colorado.

Ryan, R., 1993. Bureau of Land Management, San Juan Resource Area, personal communication to Malu Gawthrop-Cooper, Jacobs Engineering Group Inc., UPDCC File Location No. 11.2.8, Albuquerque, New Mexico, December 15, 1993.

Selby, L., 1993. Jacobs Engineering Group Inc., memo to M. B. Leaf, Jacobs Engineering Group Inc., UPDCC File Location No. 11.30.6, Albuquerque, New Mexico, March 4, 1993.

Shawe et al. (D. R. Shawe, G. C. Simmons, and N. L. Archbold), 1968. Stratigraphy of Slick Rock District and Vicinity, San Miguel and Dolores Counties, Colorado, U.S. Geological Survey Professional Paper 576-A.

TAC, 1991. "Slick Rock/Burro Canyon Monitoring," letter from TAC (JEGA/UMT/09910464) to the U.S. Department of Energy, UMTRA Project Office, Albuquerque, New Mexico, September 11, 1991.

TAC, 1990a. "Slick Rock Radon Monitoring: Pre-Remedial Action Summary," letter from TAC (JEGA/UMT/0490-0200) to the U.S. Department of Energy, UMTRA Project Office, Albuquerque, New Mexico, April 25, 1990.

TAC, 1990b. Memo from Steve Hill to M. Matthews/M. Abrams, "Evaluation of Subsidence of Burro Canyon Site," JEGA/UMT/-590-0223, calculation by J. McBee (Calc. SRK04-90-03-03-00), UPDCC File Location No. 11.21.1, Albuquerque, New Mexico, May 16, 1990.

Tenney, B., 1990. Colorado Division of Highways, Denver, Colorado, personal communication to Sandra Beranich, Jacobs Engineering Group Inc., UPDCC File Location No. 11.2.8, Albuquerque, New Mexico, June 27, 1990.

Werkmeister, W., 1993. Bureau of Land Management, San Juan Resource Area Office, Durango, Colorado, personal communication to Sandra Beranich, UPDCC File Location No. 11.2.8, Jacobs Engineering Group Inc., Albuquerque, New Mexico, January 21, 1993.

Wong, I. G., 1984. "Seismicity of the Paradox Basin and the Colorado Plateau Interior," Technical Report ONW1-492, prepared for Battelle Memorial Institute, Columbus, Ohio.

\section{CODE OF FEDERAL REGULATIONS}

40 CFR Part 61, National Emissions Standards for Hazardous Air Pollutants, U.S. Environmental Protection Agency (1994). 
40 CFR Part 192, Health and Environmental Protection Standards for Uranium and Thorium Mill Tailings, U.S. Environmental Protection Agency (1994).

\section{DOE ORDERS}

5400.5, Radiological Protection of the Public and the Environment, February 8, 1990, U.S. Department of Energy, UMTRA Project Office, Albuquerque Operations Office, Albuquerque, New Mexico.

5480.11, Radiation Protection for Occupational Workers, December 1988, U.S. Department of Energy, UMTRA Project Office, Albuquerque Operations Office, Albuquerque, New Mexico.

\section{FEDERAL REGISTER}

52 FR 36000, Standards for Remedial Actions at Inactive Uranium Processing Sites: Proposed Rule, September 24, 1987.

58 FR 39495, Endangered and Threatened Wildlife and Plants; Proposed Rule to List the Southwestern Willow Flycatcher as Endangered With Critical Habitat, July 23, 1993.

\section{PUBLIC LAW}

PL 95-604, Uranium Mill Tailings Radiation Control Act of 1978, 42 USC $\$ 7901$, November 8, 1978, 95th Congress of the United States of America, Washington, D.C. 
ATTACHMENT 1

BIOLOGICAL ASSESSMENT 


\section{TABLE OF CONTENTS}

Section

Page

1.0 INTRODUCTION ............................. 1-1

2.0 DESCRIPTIONS OF THE PROPOSED ACTION AND STUDY AREA . . . . . . 2-1

2.1 Proposed action .......................... $2-1$

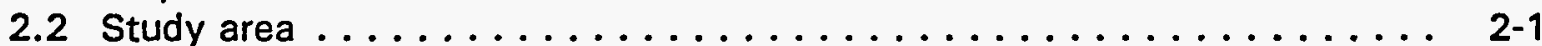

3.0 THREATENED AND ENDANGERED SPECIES $\ldots \ldots \ldots \ldots \ldots \ldots \ldots \ldots \ldots$

4.0 REFERENCES $\ldots \ldots \ldots \ldots \ldots \ldots \ldots \ldots \ldots \ldots \ldots \ldots \ldots \ldots \ldots \ldots \ldots \ldots$

APPENDIX A SECTION 7, CONSULTATION LETTERS FROM THE FISH AND WILDLIFE SERVICE

APPENDIX B FISH AND WILDLIFE SERVICE BIOLOGICAL OPINION 


\section{LIST OF FIGURES}

Figure

Page

1.1 Location of the Union Carbide and North Continent UMTRA sites near Slick

Rock, Colorado ............................... 1-2

\section{LIST OF TABLES}

Table

Page

2.1 Plant species observed in the area of the UC and NC UMTRA sites . . . . . 2-2

2.2 Fish species recorded in the Dolores River near Slick Rock, Colorado . . . . . . 2-4

2.3 Amphibians and reptiles observed or expected to occur in the area of the UC and NC UMTRA sites . . . . . . . . . . . . . . . . . . . 2-5

2.4 Bird species observed at or near the UC and NC UMTRA sites . . . . . . . 2-6

2.5 Mammals observed or expected to occur in the area of the UC and NC UMTRA sites ................................ 2-8

3.1 Threatened or endangered species and other species of concern that may occur at the UC and NC UMTRA sites near Slick Rock, Colorado . . . . . . . . . . . . 


\section{LIST OF ACRONYMS AND ABBREVIATIONS}

\section{Acronym Definition}

$\begin{array}{ll}\text { ac } & \text { acre } \\ \text { CDOW } & \text { Colorado Division of Wildlife } \\ \text { DDT } & \text { dichlorodiphenyltrichloroethane } \\ \text { DOE } & \text { U.S. Department of Energy } \\ \mathrm{ft}^{3} & \text { feet } \\ \mathrm{ft}^{3} / \mathrm{s} & \text { cubic feet per second } \\ \mathrm{FWS} & \text { Fish and Wildlife Service } \\ \mathrm{ha} & \text { hectare } \\ \mathrm{km} & \text { kilometer } \\ \mathrm{m} & \text { meter } \\ \mathrm{m}^{3} & \text { cubic meter } \\ \mathrm{mi} & \text { mile } \\ \mathrm{NC} & \text { North Continent } \\ \text { T\&E } & \text { threatened and endangered } \\ \text { UC } & \text { Union Carbide } \\ \text { UMTRA } & \text { Uranium Mill Tailings Remedial Action } \\ \text { yd } & \text { cubic yard }\end{array}$




\subsection{INTRODUCTION}

Pursuant to the Uranium Mill Tailings Radiation Control Act of 1978, the U.S. Department of Energy (DOE) is conducting a remedial action program designed to clean up the residual radioactive materials at two sites near Slick Rock, Colorado (Figure 1.1). An important part of the environmental assessment of the remedial action is the consideration of threatened and endangered (T\&E) flora and fauna that may be affected by the project. This biological assessment includes communications with the Fish and Wildlife Service (FWS) to ascertain their concerns regarding T\&E species. In February 1986, the FWS provided a list of species that may occur near the Slick Rock sites. This list was updated in December 1988, April 1990, and December 1992 (Appendix A). This assessment addresses the species listed in the December 1992 letter and includes descriptions of the proposed action, the ecological setting at the Slick Rock tailings sites, the historical and current status of the species of concern at the site, and a finding as to whether the remedial action will impact the species. 


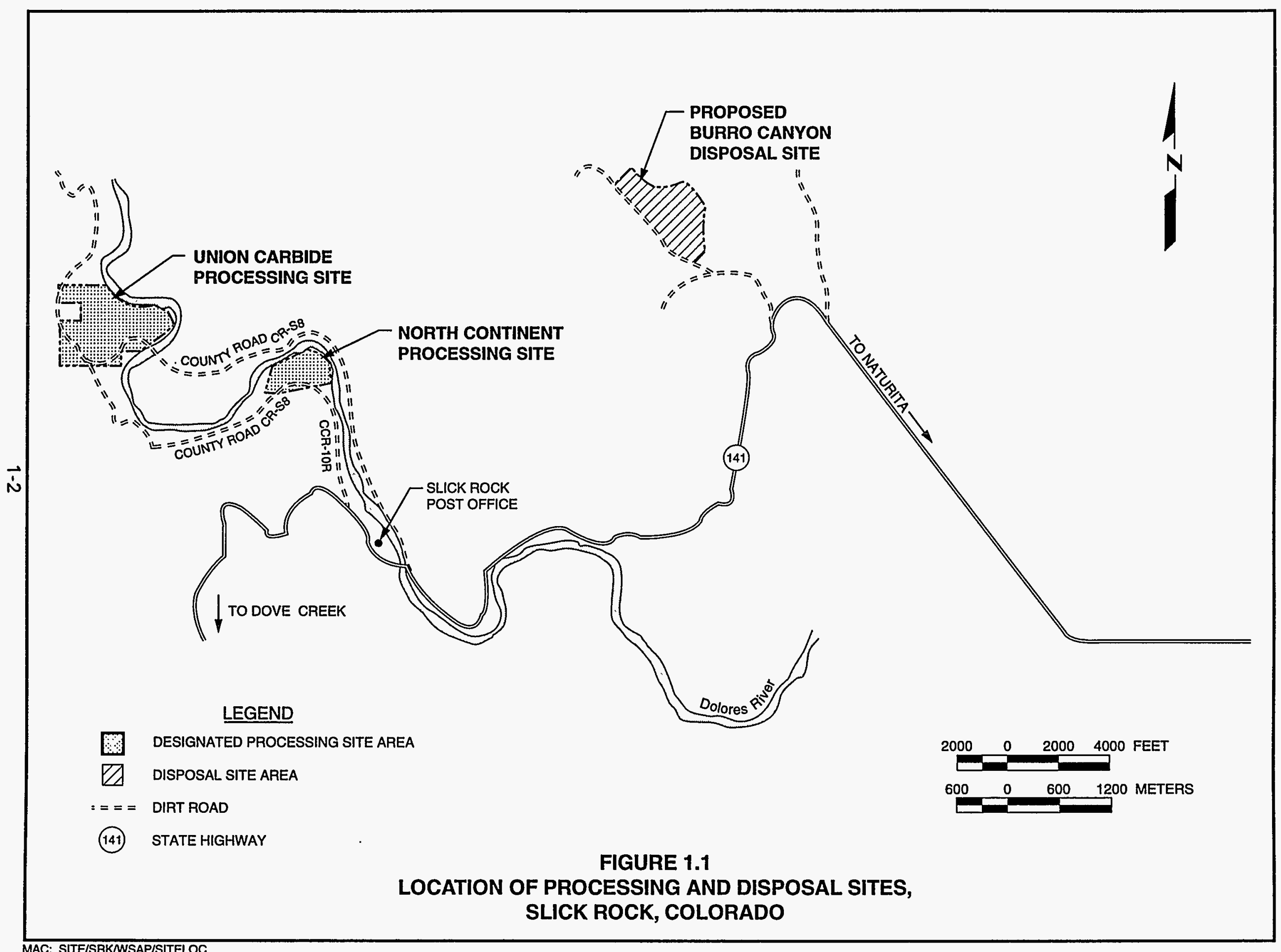




\subsection{DESCRIPTIONS OF THE PROPOSED ACTION AND STUDY AREA}

\subsection{PROPOSED ACTION}

The proposed action is to stabilize all contaminated materials at the Union Carbide (UC) and North Continent (NC) Uranium Mill Tailings Remedial Action (UMTRA) sites at the Burro Canyon disposal site. The materials to be stabilized are contaminated with low levels of radioactive and other hazardous constituents. The volume of contaminated materials is 620,000 cubic yards $\left(\mathrm{yd}^{3}\right)\left(470,000\right.$ cubic meters $\left[\mathrm{m}^{3} \mathrm{l}\right)$, covering 63 acres (ac) (26 hectares [ha]) at the UC site and $15 \mathrm{ac}(6 \mathrm{ha})$ at the NC site. The contaminated materials would be covered with a combination of earth, gravel, and rock materials to inhibit radon emanation from the contaminated materials and water infiltration through the pile and to prevent erosion of the disposal cell. Section 2.0 of this EA provides additional information on the proposed action.

The amount of land disturbed during remedial action would be 295 ac (119 ha): 78 ac (32 ha) of contaminated land; 47 ac (19 ha) of disturbed land adjacent to the NC and UC sites; 80 ac (32 ha) at the proposed disposal site; 65 ac (26 ha) at the Disappointment Valley borrow site; and $25 \mathrm{ac}$ (10 ha) at the Dolores River borrow site. Remedial action would take place over a 19-month period that includes one 5-month winter shutdown.

\subsection{STUDY AREA}

The UC, NC, Burro Canyon, and borrow sites are in Great Basin sagebrush habitat within the Colorado Plateau (Kuchler, 1975). The UC and NC tailings sites and the Dolores River borrow site are in the Dolores River valley, which is surrounded by sandstone cliffs and steep juniper-covered hillsides. Flat land is confined to the riparian zone along the river. The Burro Canyon disposal site and Disappointment Valley borrow site are in upland areas dominated by desert shrubs.

The ecological characteristics at the Slick Rock sites were determined during field surveys (TAC, 1991, 1990, 1986, 1985; DOE, 1983), consultations with natural resource personnel from state and federal agencies, and review of the pertinent literature. The flora and fauna observed or expected to occur at the sites, plus scientific names of most species referred to in the text, appear in Tables 2.1 through 2.5. The plant species list (Table 2.1) was derived from site-specific surveys and includes the more common species in the area of the sites (TAC, 1986; DOE, 1983). Surveys of fisheries were not conducted as part of this study; fish species that occur in the Dolores River were determined from other studies as referenced in Table 2.2. Surveys specifically for amphibians, reptiles, and mammals were not conducted at the sites. The occurrence of species within these groups was recorded during surveys for other purposes (Tables 2.3 and 2.5). Nesting birds along the Dolores River were identified during June 1990 and June 1991 surveys for the southwestern willow 
Table 2.1 Plant species observed in the area of the UC and NC UMTRA sites

\begin{tabular}{ccrll}
\hline & Species & & \multicolumn{2}{c}{ Habitat } \\
\cline { 1 - 1 } \cline { 5 - 5 } & & Common name & Riparian Upland \\
\hline
\end{tabular}

\section{TREES AND SHRUBS}

Acer negundo

Artemisia arbuscula

Artemisia tridentata

Atriplex canescens

Atriplex sp.

Brickellia scabra

Cercocarpus montanus

Chrysothamnus nauseosus

Chrysothamnus viscidiflorus

Elaeagnus angustifolia

Ephedra sp.

Forestera neomexicana

Gutierrezia sarothrae

Haplopappus scopurlorum

Juniperus sp.

Opuntia polyacantha

Pinus edulis

Populus angustifolia

Populus fremontii

Rhus trilobata

Rosa fendleri

Salix sp.

Sarcobatus vermiculatus

Tamarix pentandra

Yucca baccata

Yucca sp.

Amaranthus sp.

Ambrosia confertifolia

Arctium minus

Astragalus amphioxys

Astragalus sp.

Centaurea repens

Chenopodium watsoni

Chrysopsis hispida

Clematis liqusticifolia

Cleome lutea

Cleome serrulata

Descurainia obtusa box elder

black sagebrush

big sagebrush

fourwing saltbush

saltbush

brickellia

mountain mahogany

golden rabbitbrush

rabbitbrush

Russian olive

mormon tea

wild privet

broom snakeweed

goldenweed

juniper

plains prickly pear

pinon pine

narrowleaf cottonwood

Fremont cottonwood

squawbush

fendler rose

willow

greasewood

saltcedar

banana yucca

yucca

\section{FORBS AND HERBS}

pigweed

slimleaf bursage

burdock

milkvetch

milkvetch

Russian knapweed

Watson goose foot

gold aster

virgin's bower

yellow bee plant

Rocky Mountain bee plant

tansy mustard $x$

$\begin{array}{ll} & x \\ x & x \\ x & x \\ x & x \\ x & x \\ & x \\ x & \\ x & \\ x & \\ & \\ & \end{array}$

$X$

$x$

$x$

$x$

$x$

$x$

$x$

$x \quad x$

$x$

$x$

$x$

$x$

$x$

$x$

$\begin{array}{ll} & x \\ x & \\ X & x \\ x & x \\ X & x \\ X & \\ X & \\ X & \\ X & \\ X & \\ X & \end{array}$


Table 2.1 Plant species observed in the area of the UC and NC UMTRA sites (Concluded)

\begin{tabular}{ccccc}
\hline & Species & & Habitat \\
\cline { 1 - 1 } Scientific name & & Common name & & Riparian Upland \\
\hline
\end{tabular}

\section{FORBS AND HERBS (Concluded)}

Eriogonum wrightii

Glycyrrhiza lepidota

Grindelia squarrosa

Halogeton glomeratus

Helianthus annuus

Hymenopappus pauciflora

Ipomoea sp.

Ipomopsis aggregata

Lesquerella rectipes

Leucelene ericoides

Melilotus officinalis

Mirabilis multiflora

Salsola iberica

Senecio multicapitatus

Sphaeralcea coccinea

Stanleya pinnata

Agropyron desertorum

Andropogon gerardii

Bouteloua gracilis

Bouteloua sp.

Bromus rubens

Bromus tectorum

Cynodon dactylon

Hilaria jamesii

Oryzopsis hymenoides

Phragmites communis

Sitanion hystrix

Sporobolus cryptandrus

Stipa comata
Wright buckwheat

licorice

curlycup gumweed

halogeton

common sunflower

white ragweed

morning glory

desert trumpet

bladder pod

babywhite aster

yellow sweet clover

Colorado four o'clock

Russian thistle

groundsel

scarlet globe mallow

prince's plume

\section{GRASSES}

crested wheatgrass

big bluestem

blue grama

grama sp.

red brome

cheatgrass

Bermuda grass

galleta

Indian ricegrass

reed

squirrel tail

sand dropseed

needle and thread $x$

$x$

$x$

$x$

$x \quad x$

$x$

$x$

$x$

$x$

$x$

$x$

$\begin{array}{ll}x & x \\ x & x \\ x & x\end{array}$

$x$

$x$

$x$
$x$

$x$

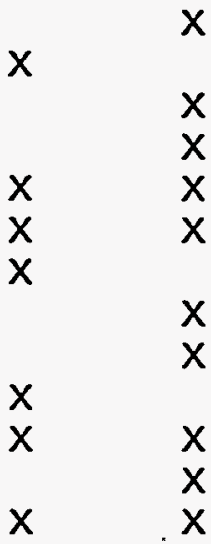

Ref. TAC, 1986; DOE, 1983. 
Table 2.2 Fish species recorded in the Dolores River near Slick Rock, Colorado

\begin{tabular}{lll}
\hline \multicolumn{1}{c}{ Scientific name } & \multicolumn{1}{c}{ Common name } & \multicolumn{1}{c}{ Status } \\
\hline Catostomus discobolus & bluehead sucker & Native \\
Catostomus latipinnis & flannelmouth sucker & Native \\
Lepomis cyanellus & green sunfish & Nonnative \\
Cottus bairdi & mottled sculpin & Native \\
Cyprinus carpio & common carp & Nonnative \\
Gila robusta & roundtail chub & Native \\
Cyprinella lutrensis & red shiner & Nonnative \\
Notropis stramineus & sand shiner & Nonnative \\
Pimephales promelas & fathead minnow & Nonnative \\
Rhinichthys osculus & speckled dace & Native \\
lctalurus punctatus & channel catfish & Nonnative \\
Ameiurus melas & black bullhead & Nonnative \\
\hline
\end{tabular}

Ref. Kehmeier, 1986; Valdez et al., 1992, 1982; Holden and Stalnaker, 1975. 
Table 2.3 Amphibians and reptiles observed or expected to occur in the area of the UC and NC UMTRA sites

\begin{tabular}{|c|c|c|c|}
\hline \multicolumn{2}{|r|}{ Species } & \multicolumn{2}{|c|}{ Habitat } \\
\hline Scientific name & Common name & Riparian & Upland \\
\hline Ambystoma tigrinum & tiger salamander & $x$ & $x$ \\
\hline Scaphiopus intermontanus & great basin spadefoot & $x$ & $\mathrm{x}$ \\
\hline Bufo punctatus ${ }^{a, b}$ & red-spotted toad & $\mathrm{x}$ & \\
\hline Bufo woodhousii $i^{a, b}$ & Woodhouse's toad & $x$ & \\
\hline Hyla arenicolor ${ }^{a, b}$ & common tree frog & $\mathrm{x}$ & \\
\hline Rana pipiens & leopard frog & $x$ & \\
\hline Crotaphytus collaris ${ }^{\mathrm{a}}$ & collared lizard & & $x$ \\
\hline Gambelia wislizenii & leopard lizard & & $x$ \\
\hline Phrynosoma douglassii & short-horned lizard & & $x$ \\
\hline Sceloporus undulatus ${ }^{\mathrm{a}}$ & eastern fence lizard & $x$ & $x$ \\
\hline Sceloporus occidentialis ${ }^{a}$ & western fence lizard & $x$ & \\
\hline Sceloporus graciosus ${ }^{a}$ & sagebrush lizard & & $x$ \\
\hline Uta stansburiana & side-blotched lizard & & $x$ \\
\hline Urosaurus ornatus & tree lizard & $x$ & $x$ \\
\hline Eumeces multivirgatus & many-lined skink & $x$ & $x$ \\
\hline Chemidophorus tigris $^{a}$ & northern whiptail & & $x$ \\
\hline Chemidophorus velox ${ }^{a}$ & plateau whiptail & & $x$ \\
\hline Coluber constrictor & racer & $x$ & $x$ \\
\hline Pituophis melanoleucus ${ }^{a}$ & gopher snake & $x$ & $x$ \\
\hline Lampropeltis triangulum & milk snake & $\mathrm{x}$ & $x$ \\
\hline Thamnophis elegans & western terrestrial garter snake & $x$ & \\
\hline Crotalus viridis & western rattlesnake & $x$ & $\mathrm{x}$ \\
\hline
\end{tabular}

aspecies observed on the site.

bobserved by Beck (1993) in canyons feeding into the Dolores River

Ref. Beck, 1993; Hammerson, 1986; TAC, 1991, 1990, 1986, 1985; DOE, 1983; Pioneer, 1979; Bernard and Brown, 1978. 
Table 2.4 Bird species observed at or near the UC and NC UMTRA sites

\begin{tabular}{|c|c|c|c|}
\hline \multicolumn{2}{|c|}{ Species } & \multicolumn{2}{|c|}{ Nesting habitat } \\
\hline Scientific name & Common name & Riparian & Upland \\
\hline Ardea herodias & great blue heron & $\mathrm{x}$ & \\
\hline Anas platyrhynchos & mallard & $\mathrm{x}$ & \\
\hline Charadrius vociferus & killdeer & $x$ & $x$ \\
\hline Actitis macularia & spotted sandpiper & $x$ & \\
\hline Cathartes aura & turkey vulture & $x$ & $x$ \\
\hline Circus cyaneus ${ }^{a}$ & northern harrier & $\mathrm{x}$ & \\
\hline Buteo jamaicensis & red-tailed hawk & $x$ & $x$ \\
\hline Falco sparverius & American kestrel & $x$ & $x$ \\
\hline Columba fasciata & band-tailed pigeon & $\mathrm{X}$ & $\mathrm{X}$ \\
\hline Columba livia & rock dove & $x$ & $x$ \\
\hline Zenaida macroura & mourning dove & $\mathrm{X}$ & \\
\hline Chordeiles minor & common nighthawk & $x$ & $x$ \\
\hline Aeronautes saxatalis & white-throated swift & $\mathrm{X}$ & $x$ \\
\hline Archilochus alexandri & black-chinned hummingbird & $x$ & $\mathrm{x}$ \\
\hline Selasphorus platycercus & broad-tailed hummingbird & $x$ & \\
\hline Ceryle alcyon & belted kingfisher & $\mathrm{x}$ & \\
\hline Colaptes auratus & northern flicker & $\mathrm{X}$ & \\
\hline Picoides villosus & hairy woodpecker & $\mathrm{X}$ & \\
\hline Melanerpes lewis & Lewis' woodpecker & $x$ & $\mathrm{X}$ \\
\hline Tyrannus verticalis & western kingbird & $\mathrm{X}$ & $x$ \\
\hline Myiarchus cinerascens & ash-throated flycatcher & $\mathrm{x}$ & $\mathrm{x}$ \\
\hline Contopus sordidulus & western wood pewee & $\mathrm{x}$ & \\
\hline Sayornis saya & Say's phoebe & $x$ & \\
\hline Empidonax wrightii & gray flycatcher & $\mathrm{X}$ & $x$ \\
\hline Eremophila alpestris. & horned lark & & $x$ \\
\hline Tachycineta thalassina & $\begin{array}{l}\text { violet-green swallow } \\
\text { northern rough-winged }\end{array}$ & $\mathrm{x}$ & \\
\hline Stelgidopteryx serripennis & swallow & $\mathrm{x}$ & \\
\hline Hirundo pyrrhonota & cliff swallow & $x$ & \\
\hline Hirundo rustica & barn swallow & $x$ & \\
\hline Aphelocoma coerulescens & scrub jay & & $x$ \\
\hline Gymnorhinus cyanocephalus & pinyon jay & $x$ & $x$ \\
\hline Pica pica & black-billed magpie & $x$ & \\
\hline Corvus brachyrhynchos & American crow & $x$ & \\
\hline Corvus corax & raven & & $x$ \\
\hline Sitta pygmaea & pygmy nuthatch & & $\mathrm{x}$ \\
\hline Troglodytes aedon & house wren & $\mathrm{X}$ & \\
\hline Catherpes mexicanus & canyon wren & & $x$ \\
\hline Salpinctes obsoletus & rock wren & & $\mathrm{x}$ \\
\hline Polioptila caerulea & blue-gray gnatcatcher & $x$ & $\mathrm{x}$ \\
\hline Sialia currucoides & mountain bluebird & & $x$ \\
\hline
\end{tabular}


Table 2.4 Bird species observed at or near the UC and NC UMTRA sites (Concluded)

\begin{tabular}{|c|c|c|c|}
\hline \multicolumn{2}{|c|}{ Species } & \multicolumn{2}{|c|}{ Nesting habitat } \\
\hline Scientific name & Common name & Riparian & Upland \\
\hline Turdus migratorius & American robin & $x$ & \\
\hline Lanius Iudovicianus & loggerhead snake & $x$ & $x$ \\
\hline Mimus polyglottos & northern mockingbird & $x$ & $x$ \\
\hline Toxostoma bendirei & Bendire's thrasher & & $x$ \\
\hline Bombaycilla cedrorum & cedar waxwing & $\mathrm{x}$ & \\
\hline Vireo gilvus & warbling vireo & $x$ & \\
\hline Vireo solitarius & solitary vireo & $x$ & \\
\hline Vireo vicinior & gray vireo & & $x$ \\
\hline Dendroica petechia & yellow warbler & $\mathrm{X}$ & \\
\hline Icteria virens & yellow-breasted chat & $x$ & \\
\hline Pheucticus melanocephalus & black-headed grosbeak & $x$ & $x$ \\
\hline Guiraca caerulea & blue grosbeak & $x$ & \\
\hline Passerina amoena & lazuli bunting & $x$ & \\
\hline Pipilo erythrophthalmus & rufous-sided towhee & $\mathrm{X}$ & \\
\hline Pooecetes gramineus & vesper sparrow & $x$ & $x$ \\
\hline Passerculus sandwichensis & savannah sparrow & $x$ & $x$ \\
\hline Chondestes grammacus & lark sparrow & $x$ & $\mathrm{x}$ \\
\hline Spizella passerina & chipping sparrow & $x$ & $x$ \\
\hline Amphispiza bilineata & black-throated sparrow & & $x$ \\
\hline Sturnella neglecta & western meadowlark & $x$ & $x$ \\
\hline Euphagus cyanocephalus & brewer's blackbird & $\mathrm{x}$ & \\
\hline Molothrus ater & brown-headed cowbird & $\mathrm{x}$ & $x$ \\
\hline Icterus galbula & northern oriole & $x$ & \\
\hline Carduelis psaltria & lesser goldfinch & $x$ & \\
\hline Carduelis tristis & American goldfinch & $x$ & \\
\hline Carpodacus mexicanus & house finch & $x$ & $\mathrm{x}$ \\
\hline
\end{tabular}

aSpecies observed only in Disappointment Valley borrow site area.

${ }^{\mathrm{b}}$ Species which nest on cliffs.

Ref. TAC, 1991, 1990, 1986, 1985; DOE, 1983; Pioneer, 1979. 
Table 2.5 Mammals observed or expected to occur in the area of the UC and NC UMTRA sites

\begin{tabular}{|c|c|c|c|}
\hline \multicolumn{2}{|c|}{ Species } & \multicolumn{2}{|c|}{ Habitat } \\
\hline Scientific name & Common name & Riparian & Upland \\
\hline Sy/vilagus nuttallii & mountain cottontail & $x$ & \\
\hline Sylvilagus audubonii ${ }^{a}$ & desert cottontail & & $x$ \\
\hline Lepus californicus & black-tailed jackrabbit & & $x$ \\
\hline Eutamias minimus ${ }^{a}$ & least chipmunk & & $x$ \\
\hline Ammospermophilus leucurus ${ }^{a}$ & $\begin{array}{l}\text { white-tailed antelope ground } \\
\text { squirrel }\end{array}$ & & $x$ \\
\hline Spermophilus richardsonii ${ }^{a}$ & Richardson's ground squirrel & $x$ & $x$ \\
\hline Spermophilus variegatus & rock squirrel & & $x$ \\
\hline Thomomys talpoides & northern pocket gopher & $x$ & $x$ \\
\hline Perognathus flavus & silky pocket mouse & & $x$ \\
\hline Dipodomys ordii ${ }^{\text {a }}$ & Ord's kangaroo rat & $x$ & $x$ \\
\hline Castor canadensis ${ }^{\mathrm{a}}$ & beaver & $x$ & \\
\hline Peromyscus crinitus & canyon mouse & & $x$ \\
\hline Peromyscus maniculatus ${ }^{a}$ & deer mouse & $x$ & $x$ \\
\hline Peromyscus truei ${ }^{a}$ & pinon mouse & & $x$ \\
\hline Onychomys leucogaster ${ }^{a}$ & northern grasshopper mouse & & $x$ \\
\hline Neotoma lepida ${ }^{a}$ & desert woodrat & & $x$ \\
\hline Ondatra zibethicus ${ }^{a}$ & muskrat & $x$ & \\
\hline Zapus princeps & western jumping mouse & $x$ & \\
\hline Erethizon dorsatum ${ }^{\mathrm{a}}$ & porcupine & $x$ & $x$ \\
\hline Canis latrans ${ }^{\mathbf{a}}$ & coyote & $x$ & $x$ \\
\hline Urocyon cinereoargenteus & gray fox & $x$ & $x$ \\
\hline Procyon lotor a & raccoon & $x$ & $x$ \\
\hline Mustela frenata & long-tailed weasel & $x$ & $x$ \\
\hline Mustela vison & mink & $x$ & \\
\hline Taxidea taxus & badger & $x$ & $x$ \\
\hline Spilogale gracilis & western spotted skunk & $x$ & $x$ \\
\hline Mephitis mephitis ${ }^{\mathrm{a}}$ & striped skunk & $x$ & $x$ \\
\hline Lutra canadensis ${ }^{\mathrm{a}}$ & river otter & $x$ & \\
\hline Felis rufus ${ }^{\mathrm{a}}$ & bobcat & $x$ & $x$ \\
\hline Odocoileus hemionus ${ }^{\mathrm{a}}$ & mule deer & $x$ & $x$ \\
\hline Antilocapra americana $a^{a, b}$ & pronghorn antelope & & $x$ \\
\hline Ovis conadesis mexicana & desert bighorn sheep & $\mathrm{x}$ & $x$ \\
\hline
\end{tabular}

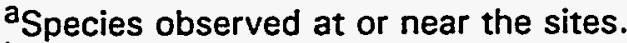

${ }^{b}$ Species observed only in Disappointment Valley borrow site area.

Ref. TAC, 1986; DOE, 1983; Pioneer, 1979; Bernard and Brown, 1978. 
flycatcher, and this listing is considered fairly complete. Other bird species would be expected at the sites either during the winter or as migrants.

\section{Union Carbide and North Continent sites}

Six plant community types were observed: disturbed grassland, desert shrub, and four riparian plant communities. The grass/herb type occurs on the tailings piles and other nearby disturbed areas. The UC tailings pile was planted with crested wheatgrass; Indian ricegrass and red brome are other grass species that occur sporadically. Widely scattered shrubs, including fourwing saltbush and rabbitbrush, also occur on this pile. Vegetative growth on the pile was sparse, and there is much bare ground. The NC tailings pile has a more developed plant cover than the UC pile. Commonly observed grass species include cheatgrass, red brome, and Indian ricegrass. Major shrub species observed include saltbush, rabbitbrush, and broom snakeweed. Herbs such as licorice, desert trumpet, scarlet globemallow, and prince's plume were also observed on the NC pile (DOE, 1983).

Within the desert shrub type, widely scattered shrubs (sagebrush, rabbitbrush, and broom snakeweed) were the dominant species in these areas. Ground cover was sparse and various grass and herb species were observed.

The four riparian vegetation plant communities consist of the dense riparian shrub type closest to the river, the upper riparian shrub and grassland types at a somewhat higher elevation above the river, and cottonwood stands. A more detailed description of the riparian plant communities is provided in Attachment 2 of this EA.

The Dolores River in the area of the Slick Rock sites traverses narrow canyons and consists of riffles, pools, and slow runs. Flow rates in the Dolores River in the area of the Slick Rock sites are dominated by releases from McPhee Dam. During the drought years of 1988 through 1991, low flows of 20 to 50 cubic feet per second $\left(\mathrm{ft}^{3} / \mathrm{s}\right)\left(0.57\right.$ to 1.42 cubic meters per second $\left.\left[\mathrm{m}^{3} / \mathrm{s}\right]\right)$ were common (Valdez et al., 1992). A recent 2-year study of the fisheries of the Dolores River resulted in the identification of 12 species from the river in the area of the sites; five of these were native and seven were nonnative species (Table 2.2) (Valdez et al., 1992). Native species were predominant, with the flannelmouth sucker and the roundtail chub being the most common. Over a 10-year period from 1981 to 1991, a decrease in the roundtail chub and an increase in the flannelmouth sucker were noted (Valdez et al., 1982, 1992).

Detailed studies of terrestrial wildlife at the tailings sites were not conducted. Reconnaissance surveys at and near the sites (TAC, 1991, 1990, 1986, 1985), studies by Beck (1993), and surveys in nearby Disappointment Valley (Pioneer, 1979 ) resulted in the observation of 11 species of reptiles and amphibians. An additional 11 species may occur at or near the sites.

A total of 66 species of birds were observed at or near the UC and NC sites (Table 2.4) (TAC, 1991, 1990, 1986, 1985). These observations resulted in a 
fairly complete list of nesting species, along with a few species that are migrants or nest some distance from the sites. The yellow-breasted chat, blue grosbeak, and yellow warbler were commonly observed in the dense brushy riparian habitat along the river. The western wood pewee, mourning dove, and robin were frequently observed in the cottonwood stands and in the nearby open shrub riparian habitat.

Very few waterbird species (i.e., waterfowl, wading birds, shore-birds) were observed near the Dolores River. The river does not provide nesting waterfowl habitat because there is a lack of brood-rearing habitat, especially with the summer drawdown of the river, although one mallard brood was observed along the river in 1990 (TAC, 1990). Waterfowl winter along the river in very small numbers (BLM, 1980). The other water bird species recorded were the great blue heron and the spotted sandpiper.

Two species of raptors observed near the tailings sites were the red-tailed hawk and the kestrel. These species probably nest in the cottonwood stands along the river or on cliffs adjacent to the river. An aerial (helicopter) survey for nesting raptors was conducted by the FWS along the river; no nesting raptors were located during this survey (FWS, 1987a).

A total of 32 species of mammals have been observed or may occur at the UC and NC sites (Table 2.5). Nineteen of these species were observed on the sites or in nearby Disappointment Valley (Beck, 1993; TAC, 1991, 1990, 1986, 1985; Pioneer, 1979). Fresh beaver signs (cuttings) were commonly observed along the river and within the dense riparian shrub habitat. The only large ungulate species observed near the UC and NC sites was the mule deer. The UC and NC sites are summer range for this species and its droppings were common in the Dolores River floodplain. Other species recorded from tracks along the river were the raccoon, skunk, river otter (discussed in detail below), bear, muskrat, and bobcat. The desert bighorn sheep was released by the Colorado Division of Wildlife (CDOW) along the Dolores River starting in 1986. The population is doing well and regularly occurs in the Slick Rock area.

\section{Burro Canyon site}

The Burro Canyon disposal site area is in an upland area above the Dolores River Valley. The site itself is grass-dominated, with widely-scattered herbs such as scarlet globe mallow also observed. Widely-scattered shrubs occur in the area, with fourwing saltbush, being the most common species observed. Prickly pear is also fairly common. The disposal site area is surrounded by low ridges covered with pinon pine/juniper woods. Big sagebrush, black sagebrush, and broom snakeweed are common shrubs. Species of cactus observed in these woods are claret cup, Simpson bell cactus, and Whipple's claw cactus (TAC, 1990). 


\section{Borrow sites}

The Dolores River borrow site is located on a terrace above the Dolores River. Part of the area is cleared pasture, with a vegetative cover dominated by grass and herbs. The remainder of the borrow site is desert-shrub habitat similar to that described above for the UC and NC tailings sites. Wildlife that would occur at this borrow site are similar to those described for the tailings sites, except that open-ground nesting birds such as the meadowlark and horned lark should be more common.

The Disappointment Valley borrow site is located on relatively flat terrain about 4.5 miles (mi) ( 7.2 kilometers [km]) east of the tailings sites. This site is located in desert-shrub habitat where relatively low-growing black greasewood 11 to 3 feet [ft] high) (0.3 to 0.9 meters [m] high) was the dominant shrub species observed. Widely-scattered fourwing saltbush, rabbitbrush, and big sagebrush were also noted. Grass was the dominant ground cover (mostly blue grama), along with scattered herbs. Wildlife indicative of upland shrub habitat occurs at this borrow site. The horned lark, western meadowlark, vesper sparrow, and black-throated sparrow were the most common nesting bird species in the grassland and shrub habitats near the site (Pioneer, 1979). 


\subsection{THREATENED AND ENDANGERED SPECIES}

The listing of T\&E and other species of concern that may occur in the area of the UC and NC sites was obtained through consultation with the FWS (see Appendix A for FWS letters). This process identified 11 species that may occur at the site (Table 3.1). Of this total, seven are federally listed species and four are federal candidate species.

Table 3.1 Threatened or endangered species and other species of concern that may occur at the UC and NC UMTRA sites near Slick Rock, Colorado

\begin{tabular}{|c|c|c|c|c|}
\hline \multicolumn{2}{|c|}{ Species } & \multirow{2}{*}{$\begin{array}{c}\text { Federal } \\
\text { listed }\end{array}$} & \multirow{2}{*}{$\begin{array}{c}\text { Federal } \\
\text { candidate }\end{array}$} & \multirow{2}{*}{$\begin{array}{l}\text { State } \\
\text { species }\end{array}$} \\
\hline Scientific name & Common name & & & \\
\hline Gila elegans & bonytail chub & $\mathrm{x}$ & & $x$ \\
\hline Gila cypha & humpback chub & $x$ & & $x$ \\
\hline Ptychocheilus Iucius & Colorado squawfish & $x$ & & $x$ \\
\hline Xyrauchen texanus & razorback sucker & $x$ & & \\
\hline Haliaeetus leucocephalus & bald eagle & $x$ & & $x$ \\
\hline Falco peregrinus & peregrine falcon & $x$ & & $x$ \\
\hline Mustela nigripes & black-footed ferret & $x$ & & $x$ \\
\hline Chlidonias niger & black tern & & $x$ & \\
\hline Empidomax trailii extimus & $\begin{array}{l}\text { southwestern willow } \\
\text { flycatcher }\end{array}$ & & $x$ & \\
\hline Plegadis chihi & white-faced ibis & & $x$ & \\
\hline Lutra canadensis sonorae & southwestern otter & & $x$ & $x$ \\
\hline
\end{tabular}

Of the 11 species listed, 4 are fish species. Fish sampling in 1971, and more recently in 1981, failed to result in the capture of bonytail chub, humpback chub, Colorado squawfish, or razorback sucker in the Dolores River. Valdez et al. (1982) not only failed to capture any bonytail chub, humpback chub, or razorback sucker, they also found no records of these species being observed or captured in the Dolores River. The Colorado squawfish occurred historically in the Dolores River but was probably absent from the river by 1960 (Sigler et al., 1966). Valdez et al. (1982) indicated that Dolores River flow reductions due to irrigation, dominance of nonnative fish species, and point-source pollution are the principal factors that have resulted in the elimination of T\&E species from the Dolores River. However, the Colorado squawfish may be coming back to the Dolores River. Four squawfish were captured in the lower $1.2 \mathrm{mi}(2 \mathrm{~km})$ of the river in 1991 , which is about 120 miles $(192 \mathrm{~km})$ downriver from the Slick Rock sites. An analysis of the Dolores River indicated that it may be suitable for all life stages of the Colorado 
squawfish. The principal factors that may limit the river's ability to support the squawfish are low flows in the summer and potentially lethal levels of copper and iron that are released into the river during summer floods caused by intense rain storms (Valdez et al., 1992). Valdez et al. (1992) recommended that experimental stocking of the Dolores River with Colorado squawfish and razorback sucker be considered. The purpose of this would be to conduct various studies on these endangered species. However, the potential for these fish being introduced to the Dolores River within the next few years is low because an augmentation plan for these species has not been finalized, and other rivers have a higher priority for being stocked with these species (Rose, 1993).

The four endangered fish species do not occur anywhere near the Slick Rock sites; therefore, remedial action activities would not have a direct impact on them. However, the proposed remedial action may have an indirect impact on these endangered fish. The FWS has determined that the continued existence of the Colorado squawfish, bonytail chub, humpback chub, and razorback sucker in the Upper Colorado River Basin (which includes the Dolores River) is in jeopardy due to depletion of water within the basin (FWS, 1987b). Water required for remedial action would result in a net depletion of water within the basin, which may have a negative impact on these species and would result in a "may affect" determination by the FWS. This determination requires the initiation of a formal consultation with the FWS under the Endangered Species Act. According to the "Recovery Implementation Program for Endangered Fish Species in the Upper Colorado River Basin" (FWS, 1987b), water depletion subject to a "may affect" determination would require a one-time contribution to the FWS of $\$ 11.98$ per acre-foot of water used based on the average annual project depletion. Water for remedial action would be obtained from the Dolores River or from aquifers hydraulically connected to the river. This water use would be subject to the one-time contribution to the FWS. Approximately 93 acre-feet of water would be required during the 19 -month remedial action period. The annual water use would be approximately 59 acre-feet and would be subject to the $\$ 11.98$ per acre-foot contribution.

The bald eagle is not known to nest along the Dolores River but does occur along the river during the winter. Winter use is very dispersed (BLM, 1980) and consists principally of diurnal feeding activities (Button, 1986). There are no known nocturnal roost sites along the river. The nearest nocturnal roost to the Slick Rock sites is 7 miles $(11 \mathrm{~km})$ to the southeast along Disappointment Creek in Disappointment Valley. The roost site is in a stand of large, old cottonwoods. The number of bald eagles that roost at this site is directly proportional to the severity of the winter (Button, 1986). The closest roost site to the Disappointment Valley borrow site is $1.5 \mathrm{mi}(2.4 \mathrm{~km})$ to the south-southeast; 10 bald eagles were counted at this site in 1991 and 1992 (Clark, 1993). Remedial action activities would not have a direct impact on wintering bald eagles, since the Project would either be shut down during the bald eagle wintering period or only limited activity, such as building demolition, would take place. In addition, bald eagle use of the nocturnal roost site in Disappointment Valley would not be affected due to the same shutdown. Winter bald eagle use of the Dolores River may be indirectly affected by the cleanup of the contaminated riparian zone, which could mean clearing all the large cottonwoods. These trees provide potential diurnal roost sites for eagles hunting in the area. The one contaminated area with large cottonwoods is across the river from the UC site; this area would not be disturbed because supplemental standards would be applied to this area. 
Therefore, remedial action activities are not expected to affect wintering bald eagles along the Dolores River or in Disappointment Valley.

Historically, the peregrine falcon nested in at least 27 locations in Colorado. By 1972, there were eight known nesting locations, none of which produced any young. This drastic reduction was due to the widespread use of dichlorodiphenyltrichloroethane (DDT) (Scott, 1985). The peregrine falcon recovery program began in 1975; as of 1987, the total number of breeding pairs had increased to 23 , with 22 pairs successfully fledgling young (CDOW, 1988).

One of the state's successful peregrine falcon breeding territories is 8 air miles $(12 \mathrm{~km})$ from the UC and NC sites. In 1984, an adult male and immature female engaged in nesting behavior but did not lay eggs. Young were successfully fledged at this site every year since 1985 (Craig, 1993). Peregrine falcons have also been observed engaged in nesting behavior at another site, which is also 8 air miles $(13 \mathrm{~km})$ from the $U C$ and NC sites. A pair occupied a territory in 1984 and produced infertile eggs. Nesting behavior was not observed in 1985 and 1986, although adult birds were in the area both years (Button, 1986; Craig, 1986). This pair successfully produced young in 1987 and has done so every subsequent year (Craig, 1993). Remedial action activities would not have a direct impact on nesting peregrines; however, peregrine falcons may travel long distances from the aerie to secure food. The UC and NC sites are within the feeding range of nesting peregrine falcons, which has been estimated to be up to $10 \mathrm{mi}(16 \mathrm{~km})$ (CDOW, 1978). In addition, preferred feeding areas are riparian habitat such as occur along the Dolores River at the Slick Rock sites (FWS, 1984). Remedial action activities would probably preclude the use of the Dolores River riparian zone in the area of the tailings piles by peregrine falcons. These activities would take place for two nesting seasons and would constitute a short-term limited impact. Following remedial action, peregrine falcon use of the riparian zone near the piles would be reduced since there would be'a reduced prey base as a result of clearing the vegetation. This impact would be relatively long-term; its duration would depend on the time taken for riparian habitat recovery. However, remedial action would take place on the periphery of the hunting territory; numerous feeding areas for the nesting peregrine falcons are located elsewhere within the range of the aerie. Therefore, remedial action is expected to have no effect on the peregrine falcon's nesting along the Dolores River (Craig, 1993).

The UC and NC sites are within the historic range of the black-footed ferret (CDOW, 1978). The most recent wild population of ferrets occurred in Wyoming (Clark et al., 1984). However, there are now no known ferret populations in the wild; the only known population is in captivity near Laramie, Wyoming (Leachman, 1987). This species is closely associated with prairie dogs in that the prairie dog is the ferret's main food source, and it uses prairie dog burrows for shelter and to raise its young (Hillman and Clark, 1980). For this reason, all prairie dog colonies are considered potential black-footed ferret habitat.

Prairie dog colonies do not occur at the tailings piles, the windblown and waterborne contaminated areas, the Burro Canyon disposal site, or the Dolores River borrow site. No prairie dog colonies were observed during a brief survey in the area of the Disappointment Valley borrow site. However, surveys near the proposed site indicate that the Gunnison prairie dog (Cynomys gunnisoni) is a common inhabitant of the grassland areas in Disappointment Valley (Pioneer, 1979). More detailed surveys for the prairie dog will be 
conducted in Disappointment Valley once the exact location of the borrow site is known. Remedial action activities at the UC or NC, Burro Canyon disposal, or Dolores River borrow sites would not affect the black-footed ferret.

The remaining four species in Table 3.1 are federal candidate species. The white-faced ibis breeds in colonies in freshwater marshes, from eastern Oregon sporadically across to North Dakota, and south into parts of Kansas and Colorado. It winters in the southwestern United States and Mexico. The ibis feeds in areas with extensive marshes or at ponds, and is known to fly long distances from its nest or roost site to feed in marshes and pools, along rivers and streams, and in irrigated fields. The marshes are typically dominated by tule (Scirpus sp.), cattail (Typha sp.), and reed (Phragmites sp.) (Armbruster, 1983). In western Colorado, the white-faced ibis occurs as an uncommonto-common migrant in aquatic and agricultural habitats (Kingery and Graul, 1978). This species was not observed along the Dolores River at or near the Slick Rock sites, including an 8-mile $(13-\mathrm{km})$ stretch of the river that was surveyed during the nesting season in 1990 and 1991 (TAC, 1991, 1990, 1986, 1985); however, if it did occur near the Slick Rock sites, the area along the Dolores River would be used only for feeding because there is no suitable nesting habitat. Therefore, remedial action activities would not affect this species.

The black tern is a likely breeding species in southwestern Colorado (Kingery and Graul, 1978). This species nests in marshes that are typically dominated by cattail and build their nests over water (Bergman et al., 1970; Davis and Ackerman, 1985; Dunn, 1979). The black tern has never been observed at the Slick Rock sites during wildlife surveys; these surveys included nesting bird surveys along an $8-\mathrm{mile}(13-\mathrm{km})$ stretch of the Dolores River in 1990 and 1991 (TAC, 1991, 1990, 1988, 1985). Further, suitable nesting habitat for this species does not occur along the river at or near the sites. Therefore, nesting black terns do not occur at or near the sites, and remedial action will not affect this species.

Based on trapping records, it is known that the river otter occurred in the lower Colorado River Basin, which includes the Dolores River, in the 18th and 19th centuries. A combination of overtrapping and, later, mining eliminated the river otter from the Dolores River, probably by the early 1900 s (Beck, 1987). The CDOW began planning a river otter reintroduction program in 1972. The Dolores River was chosen as a release site because the lower $180 \mathrm{mi}(290 \mathrm{~km})$ historically held this species and the present-day conditions along the river appear to provide good otter habitat.

From 1988 through 1991, 27 otters were released into the river; of these, 8 have died and 2 have moved to other river systems (Beck, 1992). Otter use of the river has concentrated in a $45-\mathrm{mi}(72-\mathrm{km})$ stretch that begins about $45 \mathrm{mi}(72 \mathrm{~km})$ upriver from the UC or NC sites, although they do not inhabit the river in the Slick Rock area (Beck, 1990, 1993). The habitat along the river provides cover (riparian vegetation and beaver dens) and food (principally crayfish [Orconectes virilis]) for the otter in the tailings site area (Beck, 1990).

Remedial action activities are not expected to have a negative impact on the river otter because no activities would take place in the river (Beck, 1993). There is a slight possibility that an otter could be struck by a haul truck due to their habit of occasionally leaving the river and running down roads (Beck, 1993). The elimination of radioactive 
materials from the floodplain may be a positive measure in that a potential source of contamination of the otters' habitat would be removed. The revegetation of riparian areas that may be cleared should take place rapidly to prevent saltcedar from revegetating the area (Beck, 1990). Willow, wild privet, sedges, and grasses should be planted. Revegetation of the wetland riparian zone along the river is discussed in Attachment 2 of the EA.

The southwestern willow flycatcher is a subspecies of the widely distributed willow flycatcher. The northern boundary of the range of E.t. extimus has not been determined, although it is believed to be in the area of the New Mexico-Colorado state line. E.t. extimus intergrades with the northern subspecies, E.t. adostas. E.t. extimus populations have declined precipitously, and the destruction of riparian habitat is the principal cause of this decline; 500 to 1000 pairs probably exist in the wild (Unitt, 1987). The southwestern willow flycatcher generally nests in willows; in recent years it has begun to nest in saltcedar (Unitt, 1987). The preferred habitat in the southwest is riparian habitat along bodies of water, such as occurs along the Dolores River. Wildlife surveys along the river in the area of the tailings sites did not result in the observation of this species (TAC, 1986, 1985). Surveys specifically for this species were conducted during June 1990 and June 1991 along an 8-mi $(13-\mathrm{km})$ stretch of the river, and the southwestern willow flycatcher was neither heard nor observed (TAC, 1991, 1990). An additional survey for this species will take place in June 1993. 


\subsection{REFERENCES}

Armbruster, J. S. ed., 1983. "Impact of Coal Surface Mining on 25 Migratory Bird Species of High Federal Interest," Fish and Wildlife Service, FWS/OBS-83/35, Fort Collins, Colorado.

BLM (U.S. Bureau of Land Management), 1980. "Bald Eagle Inventory 1978-1979, 1979-1980," BLM Montrose District Office, Montrose, Colorado.

Beck, T. D. I., 1993. Colorado Division of Wildlife, Dolores, Colorado, personal communication with Charles Burt, Environmental Services, Jacobs Engineering Group Inc., Albuquerque, New Mexico, March 29, 1993.

Beck, T. D. I., 1992.' "Development of River Otter Reintroduction Procedures, Job Progress Report for the Period July 1, 1991 - June 30, 1992," Colorado Division of Wildlife Project No. W-153-R-5, Dolores, Colorado.

Beck, T. D. I., 1990. Colorado Division of Wildlife, Dolores, Colorado, personal communication with Charles Burt, Environmental Services, Jacobs Engineering Group Inc., Albuquerque, New Mexico, May 1, 1990.

Beck, T. D. I., 1987. "Development of River Otter Reintroduction Procedures, Program Narrative," Colorado Division of Wildlife, Project No. 01-03-048, Dolores, Colorado.

Beranick, S. J., 1994. Status of Cultural Resource Activities and Field Inventories Conducted for the Slick Rock UMTRA Project Sites for the Period 1985-1993, MIS/JEG/0194-0007, available in the UMTRA Project Document Control file, No. 11.15.4, Albuquerque, New Mexico.

Bergman et al. (R. D. Bergman, P. Swain, and M. Weller), 1970. "A Comparative Study of Nesting Forsters and Black Terns," The Wilson Bulletin, Vol. 82, No. 2, pp. 435-444.

Bernard, S. R., and K. F. Brown, 1978. "Distribution of Mammals, Reptiles, and Amphibians by BLM Physiographic Regions and A. W. Kuchler's Associations for the Eleven Western States," U.S. Department of the Interior, Bureau of Land Management, Denver, Colorado.

Button, C., 1986. Bureau of Land Management, Durango, Colorado, personal communication to Chuck Burt, Environmental Services, Jacobs Engineering Group Inc., Albuquerque, New Mexico, March 6, 1986.

CDOW (Colorado Division of Wildlife), 1988. "Peregrine Falcon Restoration Program," Job Progress Report (SE-11) for the period 1 January - 31 December, 1987.

CDOW (Colorado Division of Wildlife), 1978. "Essential Habitat for Threatened or Endangered Wildlife in Colorado," Colorado Division of Wildlife, Denver, Colorado. 
Clark, H., 1993. Bureau of Land Management, Durango, Colorado, personal communication to Chuck Burt, Environmental Services, Jacobs Engineering Group Inc., Albuquerque, New Mexico, April 6, 1993.

Clark et al. (T. W. Clark, T. M. Campbell, M. H. Schroeder, and L. Richardson), 1984. "Handbook of Methods for Locating Black-Footed Ferrets," U.S. Bureau of Land Management Wildlife Technical Bulletin No. 1, Cheyenne, Wyoming.

Craig, J., 1993. Colorado Division of Wildlife, Fort Collins, Colorado, personal communication to Chuck Burt, Environmental Services, Jacobs Engineering Group Inc., Albuquerque, New Mexico, April 6, 1993.

Craig, J., 1986. Colorado Division of Wildlife, Fort Collins, Colorado, personal communication to Chuck Burt, Environmental Services, Jacobs Engineering Group Inc., Albuquerque, New Mexico, December 16, 1986.

DOE (U.S. Department of Energy). 1983. "Environmental Assessment of Remedial Actions on the Uranium Mill Tailings Near Slick Rock, Colorado," unpublished report, prepared by the U.S. Department of Energy, UMTRA Project Office, Albuquerque Operations Office, Albuquerque, New Mexico.

Davis, T. A., and R. A. Ackerman, 1985. "Adaptation of Black Tern (chlidonias niger) Eggs for Wet Loss in a Moist Nest," Auk, Vol. 102, pp. 640-643.

Dunn, E. H., 1979. "Nesting Biology and Development of Young in Ontario Black Terns," The Canadian Field Naturalist, Vol. 93, pp. 276-281.

FWS (Fish and Wildlife Service), 1987a. "Wetland Inventory and Raptor Surveys for the Rifle, Slick Rock, and Naturita Inactive Uranium Processing Sites in Western Colorado," FWS, Grand Junction, Colorado.

FWS (Fish and Wildlife Service), 1987b. "Recovery Implementation Program for Endangered Fish Species in the Upper Colorado River Basin," FWS, Region 6, Denver, Colorado.

FWS (Fish and Wildlife Service), 1984. "American Peregrine Falcon Recovery Plan (Rocky Mountain/Southwest Population)," prepared in cooperation with the American Peregrine Falcon Recovery Team, FWS, Denver, Colorado.

Hammerson, G. A., 1986. Amphibians and Reptiles in Colorado, Colorado Division of Wildlife, Department of Natural Resources, Denver, Colorado.

Hillman, C. N., and T. W. Clark, 1980. "Mustela nigripes; Audubon and Buchman, 1851," Mammalian Species, No. 126., pp. 1-3.

Holden, P. B., and C. B. Stalnaker, 1975. "Distribution of Fishes in the Dolores and Yampa River Systems of the Upper Colorado Basin," in The Southwestern Naturalist, Vol. 19, No. 4, pp. 403-412. 
Kehmeier, K., 1986. Colorado Division of Wildlife, Montrose, Colorado, personal communication to Chuck Burt, Environmental Services, Jacobs Engineering Group Inc., Albuquerque, New Mexico, December 15, 1986.

Kingery, H. E., and W. D. Graul, ed., 1978. Colorado Bird Distribution Latilong Study, prepared by the Colorado Field Ornithologists, Denver, Colorado, for Colorado Division of Wildlife, Denver, Colorado.

Kuchler, A. W., 1975. "Potential Natural Vegetation of the Conterminous United States," American Geographic Society Special Publication No. 36, New York, New York (Map).

Leachman, R., 1987. Fish and Wildlife Service, Grand Junction, Colorado, personal communication to James Anderson, U.S. Department of Energy, UMTRA Project Office, Albuquerque Operations Office, Albuquerque, New Mexico.

Pioneer (Pioneer Uravan, Inc.), 1979. "Environmental Report, San Miguel Mill Project, San Miguel County, Colorado," prepared by Dames and Moore, Denver, Colorado, for Pioneer Uravan, Inc., available in the UMTRA Project Document Control file, No. 11.19.3, Albuquerque, New Mexico.

Rose, K., 1993. Assistant Colorado State Supervisor, Fish and Wildlife Service, Grand Junction, Colorado, personal communication with Chuck Burt, Environmental Services, Jacobs Engineering Group Inc., Albuquerque, New Mexico, March 29, 1993.

Scott, J., 1985. "The Return of the Peregrine," in Colorado Outdoors, March-April, 1986, pp. 30-36.

Sigler et al. (W. F. Sigler, W. T. Helm, J. W. Angelovic, D. W. Linn, and S. S. Martin), 1966. "The Effects of Uranium Mill Waste on Stream Biota," Utah Agricultural Experiment Station Bulletin 462, Utah State University, Logan, Utah.

TAC (Technical Assistance Contractor), 1991. "Unpublished Field Notes, Slick Rock Uranium Mill Tailings Site," unpublished report prepared by the TAC, Albuquerque, New Mexico, for the U.S. Department of Energy, UMTRA Project Office, Albuquerque Operations Office, Albuquerque, New Mexico.

TAC (Technical Assistance Contractor), 1990. "Unpublished Field Notes, Slick Rock, Colorado, Uranium Mill Tailings Site," unpublished report prepared by the TAC, Albuquerque, New Mexico, for the U.S. Department of Energy, UMTRA Project Office, Albuquerque Operations Office, Albuquerque, New Mexico.

TAC (Technical Assistance Contractor), 1986. "Unpublished Field Notes, Slick Rock, Colorado, Uranium Mill Tailings Site," unpublished report prepared by the TAC, Albuquerque, New Mexico, for the U.S. Department of Energy, UMTRA Project Office, Albuquerque Operations Office, Albuquerque, New Mexico. 
TAC (Technical Assistance Contractor), 1985. "Unpublished Field Notes, Slick Rock, Colorado, Uranium Mill Tailings Site," unpublished report prepared by the TAC, Albuquerque, New Mexico, for the U.S. Department of Energy, UMTRA Project Office, Albuquerque Operations Office, Albuquerque, New Mexico.

Unitt, P., 1987. "Empidonax traillii extimus: An Endangered Subspecies," in Western Birds, Vol. 18, pp. 137-162.

Valdez et al. (R. Valdez, W. J. Masslich, and A. Wasowicz), 1992. "Dolores River Native Fish Suitability Study," final report prepared for Utah Division of Wildlife Resources, Salt Lake City, Utah.

Valdez et al. (R. Valdez, P. Mangan, M. Mclnerny, and R. P. Smith), 1982. "Colorado River Fishery Project Final Report, Field Investigations Report No. 4, Tributary Report, Fishery Investigations of the Gunnison and Dolores River," FWS, Grand Junction, Colorado. 
APPENDIX A

SECTION 7

CONSULTATION LETTERS FROM THE FISH AND WILDLIFE SERVICE 


\title{
DrIfumt: $:-1009$
}

\section{United States Department of the Interior}

\author{
FISH AND WILDLIFE SERVICE \\ Ecological Services \\ Western Colorado Office \\ 764 Horizon Drive, South Annex A \\ Grand Junction, Colorado 81506-3946
}

IN REPLY REFER TO:

ES/CO:DOE-STick Rock UMTRA Clean-up Site

MS 65412 GJ

May 24, 1994

Russe 1 Edge

Site Manager

UMTRA Project Office

P.0. Box 5400

Albuquerque, New Mexico 87115

Dear Mr. Edge:

This responds to your letter of May 5, 1994, requesting that this office review and comment on the "Environmental Assessment of Remedial Action at the Slick Rock Uranium Processing Site near Slick Rock, Colorado, Revision 2" (EA). The U.S. Fish and Wildlife Service (Service) has reviewed the subject document and offers the following comments. These comments have been prepared under the authority of, and in accordance with, the provisions of the Endangered Species Act (16 U.S.C. 1531 et. seq.) and the Fish and Wildlife Coordination Act (48 Stat. as amended; 16 U.S.C. 661 et. seq.) and constitute the report of the Department of the Interior. While your letter requested that comments be submitted on an UMTRA Document Review Form, there was no such form enclosed with your packet, so we have submitted these comments in standard letter form.

Certain changes have developed with regard to the Federally listed and candidate species discussed in your Biological Assessment (BA) since our last consultation. Those changes include;

1. Critical habitat has been officially designated for the four endangered fishes of the Colorado River Basin (Federal Register, Monday, March 21, 1994, Final Rule, Vol. 59, No. 54).

2. The southwestern willow flycatcher (Empidomax traillii extimus) has been proposed as endangered with critical habitat as of July 23, 1993.

Due to the fact that this project is not yet complete, and there is an ongoing Federal discretionary action, the above listed developments constitute grounds for reinitiation of formal consultation under section 402.16 of the section 7 interagency cooperation regulations (50 CFR 402), which states "Reinitiation of formal consultation is required... if a new species is Tisted or critical "habitat is designated that may be affected by the identified action." Therefore, the Department of Energy (DOE) will need to reinitiate formal consultation on this project.

With regards to the EA, this document is fully adequate and should only need a few minor revisions to address the new developments in the status of the 
listed species. Upon reinitiation, this office will attempt to submit a revised biological opinion as quickly as possible in order to allow this important project to proceed as soon as possible.

We appreciate the opportunity to review this document. If the Service can be of further assistance, please contact Michael Tucker at the letterhead address or (303) 243-2778.

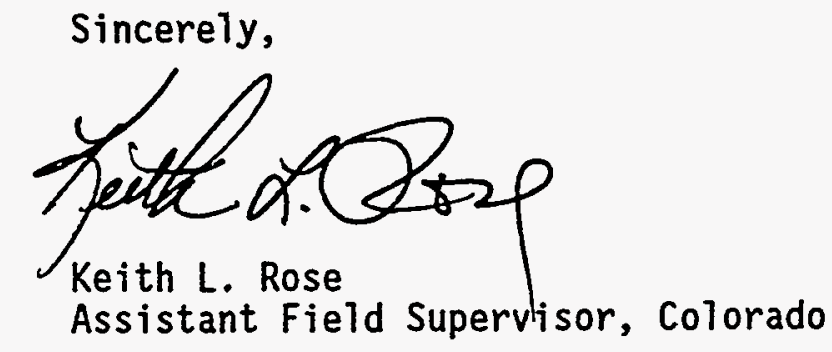

pc: FWS/ES, Golden CDOW, Montrose

MTucker:UWTRABE. Itr: 052494 


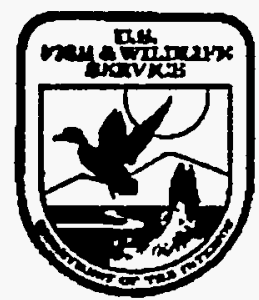

PHONE: (303) 243-2778

STATES DEPARTMENT OF THE INTERIOR FISH AND WILDLIFE SERVICE

FISH AND WILDLIFE ENHANCEMENT

Wentern Colorado Sub-Office

529 251/2 Rond, Suite B-113

Gnnd Junction, CO 81505-6199

FAX: (303) 245-6933

December 14, 1992

Linda UTland, Manager

Environmental Services

Jacobs Engineering Group

5301 Central Ave N.E., Suite 1700

Albuquerque, NM 87108

Dear Ms. UT T and:

This is in response to your request for an updated list of threatened and endangered species to be addressed in the biological assessment you are preparing for the Uranium Mill Tailings Remedial Action (UMTRA) Project near Slick Rock, San Miguel County, Colorado.

The following threatened or endangered species may occur in the project area or be impacted by the project:

B1ack-footed ferret

Mustela nigripes

If there are prairie dogs in the project area, surveys for the black-footed ferret may be required.

Bald eagle Haliaeetus leucocephalus

Our previous letters indicated that bald eagles may visit the area.

Peregrine falcon

Falco peregrinus

There are two Peregrine falcon eyries within 10 miles of the project area.

If there is any change in water quality or a depletion of water from the Colorado River or its tributaries as a result of the project, there may be an effect on the endangered Colorado River fishes:

Bonytail chub

Colorado squawfish

Humpback chub

Razorback sucker
Gila elegans

Ptychocheilus lucius

Gila cypha

Xyrauchen texanus

The following species are candidates for official listing as threatened or endangered species. These species are associated with riparian and wetland habitats in western colorado. If the project is expected to impact riparian 
habitats, the effects on these candidate species should be addressed in the biological assessment.

\section{Black tern Southwestern willow flycatcher White-faced ibis \\ Southwest otter}

\author{
Childonias niger \\ Empidomax trailii extimus \\ plegadis chihi \\ Lutra canadensis sonorae
}

Previous surveys for the UMTRA project indicated that there are no federally listed or candidate plant species in the project area.

If the Service can be of further assistance, please contact Lucy Jordan at the letterhead address or (303) 243-2778.

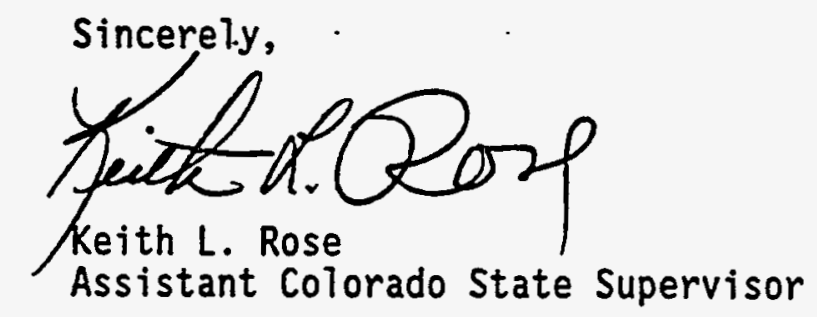

cc: FWS/FWE, Golden

FWS/FWE, Salt Lake City

CDOW, Montrose

LJordan:sl ikrock. let: 120492 


\title{
United States Department of the Interior
}

\author{
FISH AND WILDLIFE SERVICE \\ COLORADO FIELD OFFICE \\ 730 SIMMS STREET \\ ROOM 292 \\ GOLDEN, COLORADO 80401
}

IN REPLY REFER TO:

FWE/CO:DOE:UMTRA

Mail-Stop 65412 Grand Junction APR 061990

Mr. Charles J. Burt

Environmental Specialist

Jacobs Engineering Group, Inc.

5301 Central Avenue N.E. Suite 1700

Albuquerque, New Mexico 87108

Dear Mr. Burt:

This responds to your February 26, 1990, letter requesting an update of federally listed species that may be associated with the proposed Uranium Mill Tailings Remedial Action Projects at Slick Rock and Maybe11, Colorado.

We have reviewed the lists provided to Jacobs Engineering, Inc. in 1986 and 1988. The following changes should be made:

1). Slick Rock site

ADD: $\quad$ Southwestern otter (Lutra canadensis sonorae) as a Candidate 2 species

DELETE: Long-billed curlew (Numenius americanus)

Swainson's hawk (Buteo swainsoni)

White-faced ibis (Plegadis chihi)

Spotted bat (Euderma maculatum)

2) Maybell site

ADD: $\quad$ Columbian sharptailed grouse (Iympanuchus phasianellus columbianus) and the Hestern snowy plover (Charadrius alexandrinus rivosus)

DELETE: Long-billed curlew (Numenius americanus)

Swainson's hawk (Buteo swainsoni)

White-faced ibis (Plegadis chihi)

Spotted bat (Euderma maculatum) 
We appreciate the opportunity to update the species lists for these actions. Please contact John Anderson in our Grand Junction office at (303) 243-2778 if there are any questions.

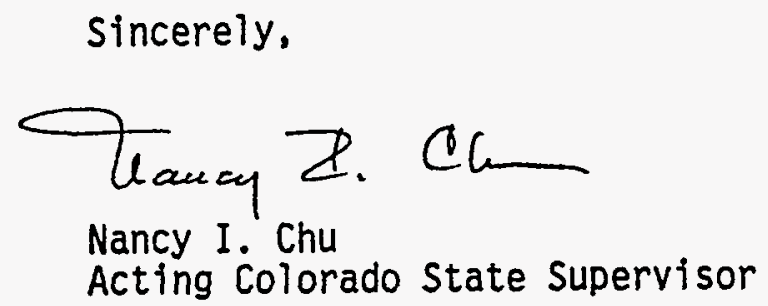

cc: FWS/FWE, Grand Junction FWS/FWE, Salt Lake City CDOW, Grand Junction 


\section{United States Department of the Interior \\ FISH AND WILDLIFE SERVICE \\ COLORADO HIELD OFFICE \\ INO SIMMS STREET \\ ROOM 292 \\ COLDEN, COLORADO COAOI}

us abery atora no

(FWE)

December 28, 1988

Charles J. Burt

Environmental Specialist

Jacobs Engineering Group. Inc.

5301 Central Avenue H.E. Sufte 1700

Alburquerque, New Mexico 87108

Dear Mr. Burt:

This responds to your November 21, 1988, letter requesting an update of Federally listed species that may be associated with the proposed Uranium Mili-taliings Renedial Action Projects at Slickrock, Naturita, Gunnison and Maybell, Colorado.

He have reviewed the lists provided to Jacobs Engineering. Inc. in 1986 and 1988. The following changes should be made:

1) Naturita site - Delete the Grand Junction milkvetch.

2) Maybell site - Delete the White River penstemon. Add the bonytail chub.

3) Gunnison site - Add the Colorado squawfish, humpback chub, and bonytait chub.

The list for the Slickrock site needs no changes.

We appreciate the opportunity to update the species lists for these actions. Piease contact Bob Leachman of our Grand Junction office at (303) 243-2773 if there are any questions.

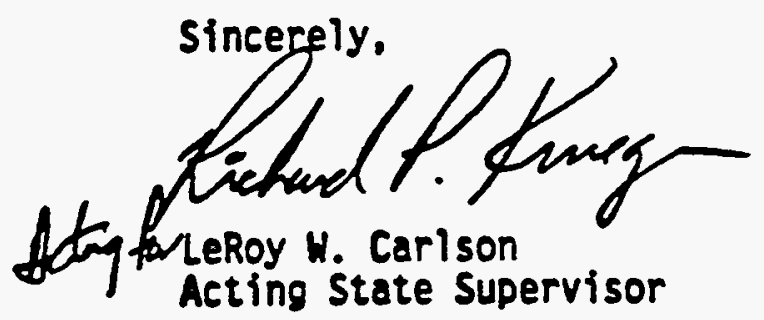

CC: FUS/FUE, Salt Lake City

Official File

Reading file 


\title{
United States Department of the Interior
}

\author{
FISH AND KILDLIFE SERVICE \\ ENDANGERED SPECIES OFFICE \\ ST 23 I TOAD \\ WDEPENDENCE PLAZA \\ SUITE B-lis \\ GRAYD JINCTION, COLORADO SIBOS \\ TELEPHONE: $303-241-0363$ \\ February 27, 1986
}

IN RETY RETER TO:

Mr. Dave Lechel

Manager, Environent al Services

Jocobs Engineering Group, Inc.

5301 Central Avenue N.W.. Suite 1700

Albuquerque, N.M. 87108

Dear Mr. Lechel:

We have received your letter of January 22, 1986, regarding Uranium Mill Tailings Kemedial Action (UMTRA) Project plans of Department of Energy for clean-up of uranium tailing sites near Naturita, Montrose County, Colorado, and near Slickrock, San Mizuel County, Colorado.

We are furnishing you with the following list of rare species which way be present within the area of influence of your project. The lists pertain to both sites with the exception noted below:

\section{Federally Listed Species}

- Bald eagle

E Black-footed ferret

$\epsilon$ Bonytail chub

EColorado squawfich

$F$ Humpback chub

E Peregrine falcon
Baliaeetus leucocephalus

Mustele nisripes

Gila elerans

Ptychocheilus lucius

Gila cyphe

Falco peregrinus (Slickrock site only)

Bistorically, the endangered black-footed ferret (Mustela nigripes) may have occurred in portions of southwestern Coloredo. Although unconfirwed cightings of this ramal have occurred in northwestern Colorado, the only known population is in Meeteetse, Hyoming. Literature documents a close association between prairie dogs and black-footed ferrets. The standard that is used for determining possible project effects to black-footed ferrets is the disturbance of currently occupied prairie dos habitat. Should any of the activities that are part of the above-referenced project result in an inpact to prairie dogs, black-footed ferret surveys may be necessary.

If water quality in the Colorado River will be affected by project activities, or If remedial action of any kind results in the consumptive use of water from the upper Colorado River basin, then resulting irpacts to the Colorado aquawish (Ptychocheilus lucius), bunpback chub (Gile cypha), and bonytail chub (Gila elegans) sust be oddressed in your assessment of impacts. 
The Jead Federal agency for Endangered Species Act (ESA) Section 7

consultation should review their proposed Federal action and determine if the action would affect any listed epecies. If the deterwination is "rny" affect" for listed species, the Federal agency wust request in writing formal consultation from the Field Supervisor. U.S. Fish and Wildlife Eervice, Endengered Species Office, 2078 Adwinistration Buldding, 1745 West 1700 South, Salt Lake City, Utah 84104. At this tive, this agency should provide this office a biological assessent and/or any other relevant information was used in raking the impact deterninetions.

He would like to bring to your attention species which are candidates for official listing as threatened or endangered species (Federal Rexister, Vol. 47. No. 251, December 30, 1982, and Vol. 50, No. 188, September 27, 1985). While these species have no legal protection at present under the Endangered Species Act, they are quite rare and restricted. We believe that it is within the opirit of the ESA to consider project impacts to candidate species at this time. Additionelly, we wish to aake you aware of the presence of Federal cendidates shoujd any be proposed or listed prior to the time thet all Federal actions related to the project are complete.

\section{Federal Candidate Speciés}

Ferruginous hawk Grand Junction milkvetch Long billed curlew Paradox Jupióne Razorback sucker Swainson's hawk White-faced ibis

\author{
Buteo reglais \\ Astragalus linifolius \\ Numenius omericanus \\ Lupinus paradox \\ Xyrauchen texanus \\ Buteo swainsoni \\ Plegadis chihi
}

The Paradox Iupine is known to occur at one of the Naturita sites. Our staff botanist has recently visited the site and confireed the presence of this rare plent.

We appreciate your interest in conserving endangered species. If you require further information on listed apecies, please contact John Anderson of our Grand Junction, Colorado office, telephone 303-241-0563.

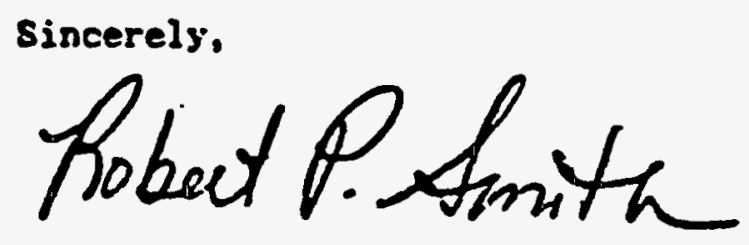

Robert P. Swith

Project Leader 


\section{APPENDIX B}

FISH AND WILDLIFE SERVICE BIOLOGICAL OPINION 


\section{DO1/UMT/0493-0010 \\ United States Department of the Interior}

FISH AND UTLDLIFE SERIICE

Mountain-Prairie Region

DN REPLYRETERTO:

FWS/ES/DOE/GJ-6

CO-93-F-034

MAIL STOP 60120
STREET LOCATION:

134 L'nion Blud.

Post Office Box

Post Office Box 2548

Denver Federal Center
Denuer, Colorado 80225

Lakwood, Colorado 80228

\section{AUG 201993}

Albert R. Chernoff, Project Manager Uranium Mill Tailings Remedial Action

Project Office, Department of Energy P.0. Box 5400

A7buquerque, New Mexico 87185-5400

Dear Mr. Chernoff:

In accordance with Section 7 of the Endangered Species Act of 1973, as amended (16 U.S.C. 1531 et seg.), and the Interagency Cooperation Regulations (50 CFR 402), this transmits the Fish and Wildlife Service's (Service) biological opinion for impacts to federally listed endangered species from the Uranium Mill Tailing clean up near Slick Rock, Colorado, in San Miguel County. This opinion is provided to you as the lead Federal Agency regarding Section 7 consultation on this project.

Reference is made to your July 29, 1993, letter requesting initiation of formal consultation for the subject project. The Service concurs that the annual depletion of water from the Colorado River Basin "may affect" the" endangered Colorado squawfish (Ptychocheilus Iucius), humpback chub (Gila cypha), bonytail chub (Gila elegans), and razorback sucker (Xyrauchen texanus). Further, the Service has determined that the water depletion will result in the destruction or adverse modification of proposed critical habitat and has included a conference opinion to address this issue.

\section{BIOLOGICAL OPINION}

Based upon the best scientific and commercial information that is currently available, it is the Service's biological opinion that the proposed project, as described below, is likely to jeopardize the continued existence of the Colorado squawfish, humpback chub, bonytail chub, and razorback sucker. The Service has developed reasonable and prudent alternatives to avoid the likelihood of jeopardy to the endangered fishes.

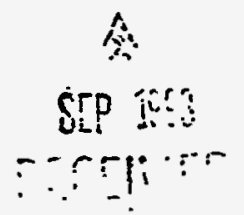


Albert R. Chernoff, Project Manager

\section{CONFERENCE OPINION}

Critical habitat has been proposed for the colorado squawfish, humpback chub, bonytail chub, and razorback sucker within the 100-year floodplain in portions of their historic range (58 F.R. 6578). Destruction or adverse modification of critical habitat is defined in 50 CFR 402.02 as a direct or indirect alteration that appreciably diminishes the value of critical habitat for both the survival and recovery of a listed species. The Service has determined that the project is likely to cause destruction or adverse modification of proposed critical habitat for the four listed endemic fishes. The Service has developed reasonable and prudent al ternatives that would avoid destruction or adverse modification to proposed critical habitat.

\section{PROJECT DESCRIPTION}

The Uranium Mill Tailings Control Act of 1978 authorized the U.S. Department of Energy to clean up two uranium mill tailings processing sites near silick Rock, Colorado, in San Miguel County. Contaminated materials cover an estimated 55 acres of the Union Carbide processing site and 12 acres of the North Continent site. The sites are within 1 mile of each other and are adjacent to the Dolores River.

Remedial action would require the use of water which would be obtained from the Dolores River or from aquifers hydraulically connected to the river. Approximately 93 acre-feet of water would be required during the 19-month remedial action period. The annual water depletion would be approximately 59 acre-feet. This water use is considered a new depletion to waters of the Upper Colorado River Basin (Upper Basin).

\section{BASIS FOR BIOLOGICAL OPINION}

This biological opinion addresses an average annual depletion of approximately 59 acre-feet from the Upper Basin. Water depletions in the Upper Bas in have been recognized as a major source of impact to endangered fish species. Continued water withdrawal has restricted the ability of the Colorado River system to produce flow conditions required by various life stages of the fishes. Impoundments and diversions have reduced peak discharges by 50 percent since 1942, while increasing base flows by 21 percent in some reaches. These depletions, along with a number of other factors, have resulted in such drastic reductions in the populations of the colorado squawfish, humpback chub, bonytail chub, and razorback sucker that the Service has listed these species as endangered and has implemented programs to prevent them from becoming extinct.

\section{BASIS FOR CONFERENCE OPINION}

In considering the biological basis for proposing critical habitat, the Service focused on the primary physical and biological elements that are essential to the conservation of the species without consideration of land or water ownership or management. The Service has identified water, physical habitat, and biological environment as the primary constituent elements. This includes a quantity of water of sufficient quality that is delivered to a 
specific location in accordance with a hydrologic regime that is required for the particular life stage for each species. Water depletions reduce the ability of the river system to provide the required water quantity and hydrologic regime necessary for recovery of the fishes. The physical habitat includes areas of the Colorado River system that are inhabited or potentially habitable for use in spawning and feeding, as a nursery, or serve as corridors between these areas. In addition, oxbows, backwaters, and other areas in the 100-year floodplain, when inundated, provide access to spawning, nursery, feeding, and rearing habitats. Water depletions reduce the ability of the river to create and maintain these important habitats. Food supply, predation, and competition are important elements of the biological environment. Food supply is a function of nutrient supply and productivity, which could be limited by reduction of high spring flows brought about by water depletions. Predation and competition from nonnative fish species have been identified as factors in the decline of the endangered fishes. Water depletions contribute to alterations in flow regimes that.favor nonnative fishes. The Service concludes that water depletions impact the primary.. constituent elements; however, reasonable and prudent alternatives have been developed by the Service that would avoid destruction or adverse modification to the proposed critical habitat.

\section{BIOLOGICAL BACKGROUND}

\section{Colorado Squawfish}

The Colorado squawfish evolved as the main predator in the Colorado River system. The diet of Colorado squawfish longer than 3 or 4 inches consists almost entirely of other fishes (Vanicek and Kramer 1969). The Colorado squawfish is the largest cyprinid fish (minnow family) native to North America and, during predevelopment times, may have grown as large as 6 feet in length and weighed nearly 100 pounds (Behnke and Benson 1983). These large fish may have been $25-50$ years of age.

Based on early fish collection records, archaeological finds, and other observations, the Colorado squawfish was once found throughout warmwater reaches of the entire Colorado River Basin, including reaches of the upper Colorado River and its major tributaries, the Green River and its major tributaries, and the Gila River system in Arizona (Seethaler 1978). Colorado squawfish were apparently never found in colder, headwater areas. Seethaler (1978) indicates that the species was abundant in suitable habitat throughout the entire Colorado River basin prior to the 1850's. Historically, Colorado squawfish have been collected in the upper Colorado River as far upstream as Parachute Creek, Colorado (Kidd 1977).

A marked decline in Colorado squawfish populations can be closely correlated with the construction of dams and reservoirs during the 1960's, introduction of nonnative fishes, and removal of water from the Colorado River system. Behnke and Benson (1983) summarized the decline of the natural ecosystem. They pointed out that dams, impoundments, and water use practices are probably the major reasons for drastically modified natural river flows and channel characteristics in the Colorado River Basin. Dams on the main stem have essentialiy segmented the river system, blocking Colorado squawfish spawning 
Albert R. Chernoff, Project Manager

migrations and drastically changing river characteristics, especially flows and temperatures. In addition, major changes in species composition have occurred due to the introduction of nonnative fishes, many of which have thrived as a result of changes in the natural riverine system (i.e., flow and temperature regimes). The decline of endemic Colorado River fishes seems to be at least partialiy related to competition or other behavioral interactions with nonnative species, which have perhaps been exacerbated by alterations in the natural fluvial environment.

The Colorado squawfish currently occupies about 1,030 river miles in the Colorado River system (25 percent of its original range) and is presently found only in the Upper Basin above Glen Canyon Dam. It inhabits about 350 miles of the main stem Green River from its mouth to the mouth of the Yampa River. Its range also extends 160 miles up the Yampa River and 104 miles up the White River, the two major tributaries of the Green River. In the main stem Colorado River, it is currently found from Lake Powell extending about 201 miles upstream to Palisade, Colorado, and in the lower 33 miles of the Gunnison River, a tributary to the main stem Colorado River (Tyus et al. 1982).

\section{Critical Habitat}

Critical habitat has been proposed within the 100-year floodplain of the Colorado squawfish's historical range in the following sections of the Upper Basin, excluding the San Juan River Basin (58 F.R. 6578).

Colorado, Moffat County. The Yampa River and its 100-year floodplain from the State Highway 394 bridge (river mile 137.7) in T. $6 \mathrm{~N}$., R. $91 \mathrm{~W}$. , section 1 (6th Principal Meridian) to the confluence with the Green River in T. 7 N., R. 103 W., section 28 (6th Principal Meridian).

Utah. Uintah. Carbon, Grand, Emery, Wayne, and San Juan Counties: and Colorado, Moffat County. The Green River and its 100-year floodplain from the confluence with the Yampa River in T. $7 \mathrm{~N} .$, R. $103 \mathrm{~W}$. , section 28 (6th Principal Meridian) to the confluence with the Colorado River in T. 30 S., R. 19 E., section 7 (Salt Lake Meridian).

Colorado, Rio Blanco County; and Utah, Uintah County. The White River and its 100-year floodplain from Rio Blanco Lake Dam (river mile 150) in T. 1 N., R. 96 W., section 6 (6th Principal Meridian) to the confiuence with the Green River in T. 9 S., R. 20 E., section 4 (Salt Lake Meridian).

Colorado, Delta and Mesa Counties. The Gunnison River and its 100-year floodplain from the confluence with the Uncompahgre River in T. $15 \mathrm{~S}$., R. $96 \mathrm{~W}$., section 11 (6th Principal Meridian) to the confluence with the Colorado River in T. I S., R. 1 W., section 22 (Ute Meridian). 
Albert R. Chernoff, Project Manager

Colorado. Mesa and Garfield Counties; and Utah, Grand, San Juan. Wayne. and Garfield Counties. The Colorado River and its 100-year floodplain from the Colorado River Bridge at exit 90 north off Interstate 70 (river mile 238) in T. 6 S., R. 93 H., section 16 (6th Principal Meridian) to North Wash, including the Dirty Devil arm of Lake Powell up to the full pool elevation, in T. 33 S., R. 14 E., section 29 (Salt Lake Meridian).

\section{Biology}

The life-history phases that appear to be most critical for the Colorado squawfish include spawning, egg fertilization, and development of larvae through the first year of iife. These phases of Colorado squawfish development are tied closely to specific habitat requirements. Natural spawning of Colorado squawfish is initiated on the descending limb of the annual hydrograph as water temperatures approach $20^{\circ} \mathrm{C}$. Spawning, both in the hatchery and in the field, generally occurs in a 2-month timeframe between July 1 and September 1, although high flow water years may suppress river temperatures and extend spawning in the natural system into September.

Temperature also has an effect on egg development and hatching. In the laboratory, egg mortality was 100 percent in a controlled test at $13^{\circ} \mathrm{C}$. At $16^{\circ} \mathrm{C}$ to $18^{\circ} \mathrm{C}$, development of the egg is slightly retarded, but hatching success and survival of larvae was higher. At $20{ }^{\circ} \mathrm{C}$ to $26{ }^{\circ} \mathrm{C}$, development and survival through the larval stage was up to 59 percent (Hamman 1981). Juvenile temperature preference tests showed that preferred temperatures ranged from $21.9^{\circ} \mathrm{C}$ to $27.6^{\circ} \mathrm{C}$. The most preferred temperature for juveniles and adults was estimated to be $24.6^{\circ} \mathrm{C}$. Temperatures near $24^{\circ} \mathrm{C}$ are also needed for optimal development and growth of young (Miller et al. 1982).

Only two Colorado squawfish confirmed spawning sites, as defined in the Colorado Squawfish Recovery Plan, have been located in the Basin: river mile 16.5 of the Yampa River and river mile 156.6 of the Green River. These areas have the common characteristics of coarse cobble or boulder substrates forming rapids or riffles associated with deeper pools or eddies. It is believed that a stable, clean substrate is necessary for spawning and incubation. Substrates are swept clean of finer sediments by high flows scouring the bed prior to the spawning period.

O'Brien (1984) studied the hydraulic and sediment transport dynamics of the cobble bar within the Yampa River spawning site and duplicated some of its characteristics in a laboratory flume study. Based on field observations, he reported:

"On the rising limb of the hydrograph, sands are deposited in the cobble interstices. These sands are interchanged between the bed and the suspended zone for discharges less than bankfull. Depending on the supply-capacity relationship, either deposition or scour could be occurring. When the cobbles move, the sand, of course, is washed from the interstices and may be completely removed from around the cobbles. Rearrangement of the cobbles will result in more stability of the armor layer. On the falling limb, the armor 
layer becomes a trap for sands until finally, the sand reservoir is again filled. Without cobble movement, sand will be scoured only to a depth of one-half to one median cobble diameter below the cobble bed surface."

In the flume experiments, the sand level was observed approximately 0.50 to 1 cobble diameter below the surface of the cobble bed, which compared to field observations of sand depth at approximately 0.50 to 1 median cobble diameter. O'Brien reported a cobble size range of 50-100 $\mathrm{mm}$ with a median size of $75 \mathrm{~mm}$ at the spawning site. Milhous (1982) proposes discharges of approximately 0.50 of that required to initiate cobble movement will be capable of extracting sands and fines from the cobble substrate. Thus, after the supply of sand diminishes, flows of sufficient magnitude and duration are required to scour the cobble bed in preparation for spawning and incubation.

Although the location of spawning areas in the Colorado River is not well defined, the presence of larvae near the confluence of the Gunnison River, in the Loma to Black Rocks reach and near the confluence of the Dolores River, demonstrates that spawning does occur. Kaeding and Osmundson (1987) reported that water temperatures in the Colorado River were suitable for spawning in the Grand Junction area. In 1986, a year of high runoff, suitable temperatures for spawning $\left(20^{\circ} \mathrm{C}\right)$ occurred in the first week of August. Miller et a7. (1982) and Archer et al. (1986) demonstrated that Colorado squawfish often migrate considerable distances to spawn in the Green and Yampa Rivers, and similar movement has been noted in the main stem Colorado River.

Miller et al. (1982) concluded from collections of larvae and young-of-year below known spawning sites that there is a downstream drift of larval colorado squawfish following hatching. Extensive studies in the Yampa and upper Green Rivers have demonstrated downstream distribution of young Colorado squawfish from known spawning areas (Archer et al. 1986; Haynes et al. 1985). Miller et al. (1982) also found that young-of-year Colorado squawfish, from late summer through fall, preferred natural backwater areas of zero velocity and less than 1.5-foot depth over a silt substrate. Juvenile Colorado squawfish habitat preferences are similar to that of young-of-year fish, but they appear to be mobile and more tolerant of lotic conditions away from the sheltered backwater environment.

Information on radio-tagged Colorado squawfish that have been observed during fall suggests that fish seek out deepwater areas in the Colorado River (Miller et a1. 1982), as do many other riverine species. River pools, runs, and other deep water areas, especially in upstream reaches, are important winter habitats for Colorado squawfish.

Very little information is available on the influence of turbidity on the endangered Colorado River fishes. It is assumed, however, that turbidity is important, particularly as it affects the interaction between introduced fishes and the endemic Colorado River fishes. Because these endemic fishes have evolved under natural conditions of high turbidity, it is concluded that the retention of these highly turbid conditions is an important factor for these endangered fishes. Reduction of turbidity may enable introduced species to gain a competitive edge which could further contribute to the decline of the endangered Colorado River fishes. 


\section{Razorback Sucker}

The razorback sucker, an endemic species unique to the Colorado River Basin, was historically abundant and widely distributed within warmwater reaches throughout the Colorado River Basin. Historically, razorback suckers were fourd in the main stem Colorado River and major tributaries in Arizona, California, Colorado, Nevada, New Mexico, Utah, Hyoming, and in Mexico (Ellis 1914; Minckley 1983). Bestgen (1990) reported that this species was once so numerous that it was commonily used as food by early settlers and, further, that commercially marketable quantities were caught in Arizona as recently as 1949. In the Upper Basin, razorback suckers were reported in the Green River to be very abundant near Green River, Utah, in the late 1800's (Jordan 1891). An account in Osmundson and Kaeding (1989) reported that residents living along the Colorado River near Clifton, Colorado, observed several thousand razorback suckers during spring runoff in the 1930's and early 1940's. In the San Juan River drainage, Platania and Young (1989) relayed historical accounts. of razorback suckers ascending the Animas River to Durango, Colorado, around the turn of the century.

A marked decline in populations of razorback suckers can be attributed to construction of dams and reservoirs, introduction of nonnative fishes, and removal of large quantities of water from the Colorado River system. Dams on the main stem Colorado River and its major tributaries have segmented the river system and drasticaliy altered flows, temperatures, and channel geomorphology. Major changes in species composition have occurred due to the introduction of numerous nonnative fishes, many of which have thrived due to man-induced changes to the natural riverine system.

The current distribution and abundance of the razorback sucker have been significantly reduced throughout the Colorado River system (McAda 1987; McAda and Wydoski 1980; Holden and Stalnaker 1975; Minckley 1983; Marsh and Minckley 1989; Tyus 1987). The only substantial population of razorback suckers remaining, made up entirely of old adults (McCarthy and Minckley 1987), is found in Lake Mohave; however, they do not appear to be successfully recruiting. While limited numbers of razorback suckers persist in other locations in the Lower Colorado River, they are considered rare or incidental and may be continuing to decline.

In the Upper Basin, above Glen Canyon Dam, razorback suckers are found in limited numbers in both lentic and lotic environments. The largest population of razorback suckers in the Upper Basin is found in the upper Green River and lower Yampa River (Tyus 1987). Lanigan and Tyus (1989) estimated that from 758 to 1,138 razorback suckers inhabit the upper Green River. In the Colorado River, most razorback suckers occur in the Grand Valley area near Grand Junction, Colorado; however, they are increasingly rare. Osmundson and Kaeding (1991) report that the number of razorback sucker captures in the Grand Junction area has declined dramatically since 1974.

Razorback suckers are in imminent danger of extirpation in the wild. The specific causes of this species' continued decline are largely unknown at this time. As Bestgen (1990) pointed out: 
"Reasons for decline of most native fishes in the Colorado River Basin have been attributed to habitat loss due to construction of mainstream dams and subsequent interruption or alteration of natural flow and physio-chemical regimes, inundation of river reaches by reservoirs, channelization, water quality degradation, introduction of nonnative fish species and resulting competitive interactions or predation, and other man-induced disturbances (Miller 1961, Joseph et al. 1977, Behnke and Benson 1983, Carlson and Muth 1989, Tyus and Karp 1989). These factors are aimost certainly not mutualiy exclusive, therefore it is often difficult to determine exact cause and effect relationships."

The virtual absence of any recruitment suggests a combination of biological, physical, and/or chemical factors that may be affecting the survival and recruitment of early 1 ife stages of razorback suckers. Within the Upper Basin, recovery efforts endorsed by the Recovery Implementation Program. include the capture and removal of razorback suckers from all known locations for genetic analyses and development of discrete brood stocks if necessary. These measures have been undertaken to develop refugia populations of the razorback sucker from the same genetic parentage as their wild counterparts such that, if these fish are genetically unique by subbasin or individual population, then separate stocks will be available for future augmentation. Such augmentation may be a necessary step to prevent the extinction of razorback suckers in the Upper Basin.

\section{Critical Habitat}

Critical habitat has been proposed within the 100-year floodplain of the razorback sucker's historical range in the following sections of the Upper Basin, excluding the San Juan River Basin (58 F.R. 6578).

Colorado, Moffat County. The Yampa River and its 100-year floodplain from the mouth of Cross Mountain Canyon in T. 6 N., R. 98 W., section 23 (6th Principal Meridian) to the confluence with the Green River in T. 7 N., R. 103 H., section 28 (6th Principal Meridian).

Utah, Uintah County: and Colorado, Moffat County. The Green River and its 100-year floodplain from the confluence with the Yampa River in T. 7 N., R. 103 W., section 28 (6th Principal Meridian) to Sand Wash at river mile 96 in $T$. Il S., R. 18 E., section 20 (6th Principal Meridian).

Utah, Uintah, Carbon, Grand, Emery, Wayne, and San Juan Counties. The Green River and its 100-year floodplain from Sand Wash at river mile 96 at T. 11 S., R. 18 E., section 20 (6th Principal Meridian) to the confiuence with the Colorado River in T. 30 S., R. 19 E., section 7 (6th Principal Meridian).

Utah, Uintah County. The White River and its 100-year floodplain from the boundary of the Uintah and Ouray Indian Reservation at river mile 18 in T. 9 S., R. 22 E., section 21 (Salt Lake Meridian) to the confluence with the Green River in T. 9 S., R 20 E., section 4 (Salt Lake Meridian). 
Albert R. Chernoff, Project Manager

Utah, Uintah County. The Duchesne River and its 100-year floodplain from river mile 2.5 in T. 4 S., R. 3 E., section 30 (Salt Lake Meridian) to the confluence with the Green River in T. 5 S., R. 3 E., section 5 (Uintah Meridian).

Colorado, Delta and Mesa Counties. The Gunnison River and its 100-year floodplain from the confluence with the Uncompahgre River in T. $15 \mathrm{~S}$., R. 96 W., section 11 (6th Principal Meridian) to Redlands Diversion Dam in T. 1 S., R. 1 W., section 27 (Ute Meridian).

Colorado, Mesa and Garfield Counties. The Colorado River and its 100-year floodplain from Colorado River Bridge at exit 90 north off Interstate 70 (river mile 238) in T. $6 \mathrm{~S}$., R. $93 \mathrm{H}$., section 16 (6th Principal Meridian) to Westwater Canyon (river mile 125) in T. 20 S., R. 25 E., section 12 (Salt Lake Meridian) including the Gunnison River and its 100-year floodplain from the Redlands Diversion Dam in T. I S., R. 1 W., section 27 (Ute Meridian) to the confluence with the Colorado River in T. I S., R. 1 W., section 22 (Ute Meridian).

Utah, Grand, San Juan. Wayne, and Garfield Counties. The Colorado River and its 100-year floodplain from Westwater Canyon (river mile 125) in T. 20 S., R. 25 E., section 12 (Salt Lake Meridian) to full pool elevation, upstream of North Wash, and including the Dirty Devil arm of Lake Powe 77 in T. 33 S., R. 14 E., section 29 (Salt Lake Meridian).

\section{Biology}

Specific information on biological and physical habitat requirements of the razorback sucker is very limited. Until very recently, fisheries research investigations throughout the Upper Basin have focused on the three listed Colorado River fishes, and data collected on the razorback sucker was largely coincident to those studies. Localized extirpation of razorback suckers from some localities, coupled with the species' continued decline in numbers and distribution, has prompted some research; however, details of its life history requirements, particularly in riverine environments, are still not fully understood.

In general, a natural hydrograph with a large spring peak, a gradually descending limb into early summer, and low stable flows through summer, fall, and winter are thought to create the best habitat conditions for endangered fishes while maintaining the integrity of the channel geomorphology. Prior to construction of large main stem dams and the suppression of spring peak flows, low velocity, off-channel habitats (seasonally flooded bottomlands and shorelines) were commoniy available throughout the Upper Basin (Tyus and Karp 1989; Osmundson and Kaeding 1991). The absence of these seasonally flooded riverine habitats is believed to be a limiting factor in the successful recruitment of razorback suckers in their native environment (Tyus and Karp 1989; Osmundson and Kaeding 1991). Tyus (1987) and McAda and Wydoski (1980) reported springtime aggregations of razorback suckers in off-channel impoundments and tributaries that were believed to be associated with reproductive activities. Tyus and Karp (1990) and Osmundson and Kaeding (1991) reported off-channel habitats to be much warmer than the main stem 
river and that razorback suckers presumably moved to these areas for feeding, resting, sexual maturation, spawning, and other activities associated with their reproductive cycle. While razorback suckers have never been directly observed spawning in turbid riverine environments within the Upper Basin, captures of ripe specimens, both males and females, have been recorded (Valdez et a1. 1982; McAda and Hydoski 1980; Tyus 1987; Osmundson and Kaeding 1989; Tyus and Karp 1989; Tyus and Karp 1990; Osmundson and Kaeding 1991; Platania 1990) in the Yampa, Green, Colorado, and San Juan Rivers. Sexually mature razorback suckers are generally collected on the ascending limb of the hydrograph from mid-Aprif through June and are associated with coarse gravel substrates (depending on the specific location).

Outside of the spawning season, adult razorback suckers occupy a variety of shoreline and main channel habitats including slow runs, shallow to deep pools, backwaters, eddies, and other relatively slow velocity areas associated with sand substrates (Tyus 1987; Tyus and Karp 1989; Osmundson and Kaeding 1989; Valdez and Massiich 1989; Osmundson and.Kaeding 1991; Tyus and Karp 1990).

Habitat requirements of young and juvenile razorback suckers in the wild are largely unknown, particularly in native riverine environments. Life stages, other than aduits, have not been collected anywhere in the Upper Basin in recent times. The last confirmed documentation of a razorback sucker juvenile in the Upper Basin was a capture in the Colorado River near Moab, Utah (Taba et a1. 1965, reported in Bestgen 1990).

Humpback Chub

Humpback chub generally do not make migrational movements in the upper Colorado River and tend to reside throughout the year within a limited reach of river. Humpback chub are found inhabiting narrow, deep canyon areas and are relatively restricted in distribution. They seldom leave their canyon habitat (U.S. Fish and Wildlife Service 1982). While humpback chub are regularly found dispersed in the Green and Yampa Rivers, the only major populations of humpback chub known to exist in the Upper Basin are located in Black Rocks and Hestwater Canyons on the Colorado River.

Critical Habitat

Critical habitat has been proposed within the humpback chub's historical range in the following sections of the Upper Basin (58 F.R. 6578).

Colorado. Hoffat County. The Yampa River from the boundary of Dinosaur National Monument in T. 6 N., R. 99 W., section 27 (6th Principal Meridian) to the confluence with the Green River in T. 7 N., R. 103 W., section 28 (6th Principal Meridian).

Utah. Uintah County: and Colorado, Moffat County. The Green River from the confluence with the Yampa River in T. $7 \mathrm{~N} ., \mathrm{R} .103 \mathrm{~W}$. , section 28 (6th Principal Meridian) to the southern boundary of Dinosaur National Monument in T. 6 N., R. 24 E., section 30 (Salt Lake Meridian). 
Utah. Uintah and Grand Counties. The Green River (Desolation and Gray Canyons) from Sumners Amphitheater (river mile 85) in T. 12 S., R. 18 E., section 5 (Salt Lake Meridian) to Swasey's Rapid (river mile 12) in T. 20 S., R. 16 E., section 3 (Salt Lake Meridian).

Utah, Grand County: and Colorado, Mesa County. The Colorado River from Black Rocks (river mile 137) in T. 10 S., R. 104 W., section 25 (6th Principal Meridian) to Fish Ford (river mile 106) in T. 21 S., R. 24 E., section 35 (Salt Lake Meridian).

Utah, Garfield and San Juan Counties. The Colorado River from Brown Betty Rapid (river mile 212.5) in T. 30 S., R. 18 E., section 34 (Salt Lake Meridian) to Imperial Canyon (river mile 200) in T. 31 S., R. 17 E., section 28 (Salt Lake Meridian).

\section{Bonytail Chub}

Little is known about the biological requirements of the bonytail chub, as the species has drastically declined in numbers in the Upper Basin shortly after 1960. Until recently, the Service considered the species extirpated from the Upper Basin; however, a recently collected specimen which exhibits many bonytail characteristics could indicate a small, extant population. It is thought that, should this species persist in the colorado River, the preferred habitat would be in the larger river reaches.

Critical Habitat

Critical habitat has been proposed within the bonytail chub's historical range in the following sections of the Upper Basin (58 F.R. 6578).

Colorado, Moffat County. The Yampa River from the boundary of Dinosaur National Monument in T. 6 N., R. 99 W., section 27 (6th Principal Meridian) to the confluence with the Green River in T. 7 N., R. $103 \mathrm{~W}$., section 28 (6th Principal Meridian).

Utah, Uintah County: and Colorado, Moffat County. The Green River from the confluence with the Yampa River in T. 7 N., R. 103 W., section 28 (6th Principal Meridian) to the boundary of Dinosaur National Monument in T. 6 N., R. 24 E., section 30 (Salt Lake Meridian).

Utah, Uintah and Grand Counties. The Green River (Desolation and Gray Canyons) from Sumner's Amphitheater (river mile 85) in T. 12 S., R. 18 E., section 5 (Sa]t Lake Meridian) to Swasey's Rapid (river mite 12) in T. 20 S., R. 16 E., section 3 (Salt Lake Meridian).

Utah. Grand County: and Colorado. Mesa County. The Colorado River from Black Rocks (river mile 137) in T. $10 \mathrm{~S} ., \mathrm{R} .104 \mathrm{H}$., section 25 (6th Principal Meridian) to Fish Ford (river mile 106) in T. $21 \mathrm{~S}$. , R. 24 E., section 35 (Salt Lake Meridian).

Utah, Garfield and San Juan Counties. The Colorado River from Brown Betty Rapid (river mile 212.5) in T. 30 S., R. 18 E., section 34 (Salt Lake Meridian) to Imperial Canyon (river mile 200) in T. 31 S., R. 17 E., section 28 (Salt Lake Meridian). 


\section{REASONABLE AND PRUDENT ALTERNATIVES}

On January 21-22, 1988, the Secretary of the Interior; the Governors of Wyoming, Colorado, and Utah; and the Administrator of the Western Area Power Administration were cosigners of a Cooperative Agreement to implement the "Recovery Implementation Program for Endangered Fish Species in the Upper Colorado River Basin" (Recovery Program) (U.S. Fish and Wildlife Service 1987). An objective of the Recovery Program was to identify reasonable and prudent alternatives that would ensure the survival and recovery of the listed species while providing for new water development in the Upper Basin.

The following excerpts are pertinent to the consultation because they summarize portions of the Recovery Program that address depletion impacts, Section 7 consultation, and project proponent responsibilities:

"All future Section 7 consultations completed after approval and implementation of this program (establishment of the Implementation Committee, provision of congressional funding, and initiation of the elements) will result in a one-time contribution to be paid to the Service by water project proponents in the amount of $\$ 10.00$ per acre-foot based on the average annual depletion of the project .... This figure will be adjusted annually for inflation [the current figure is $\$ 11.98$ per acre-foot] . . . Concurrently with the completion of the Federal action which initiated the consultation, e.g., ... issuance of a 404 permit, 10 percent of the total contribution will be provided. The balance... will be ... due at the time the construction commences ...."

It is important to note that these provisions of the Recovery Program were based on appropriate legal protection of the instream flow needs of the endangered Colorado River fishes. The Recovery Program further states:

". . . it is necessary to protect and manage sufficient habitat to support self-sustaining populations of these species. One way to accomplish this is to provide long term protection of the habitat by acquiring or appropriating water rights to ensure instream flows.... Since this program sets in place a mechanism and a commitment to assure that the instream flows are. protected under State law, the Service will consider these elements under Section 7 consultation as offsetting project depletion impacts."

Thus, the Service has determined that project depletion impacts, which the Service has consistently maintained are likely to jeopardize the listed fishes, can be offset by (a) the water project proponents one-time contribution to the Recovery Program in the amount of $\$ 11.98$ per acre-foot of the project's average annual depletion, (b) appropriate legal protection of instream flows pursuant to State law, and (c) accomplishment of activities necessary to recover the endangered fishes as specified under the Recovery 
Implementation Program Recovery Action Plan (Plan). The Service believes it is essential that protection of instream flows proceed expeditiously, before significant additional water depletions occur.

With respect to (a) above (i.e., depletion charge), the Department of Energy will make a one-time payment which has been calculated by multiplying the project's average annual depletion (59 acre-feet) by the depletion charge in effect at the time payment is made. For Fiscal Year 1993 (October 1, 1992, to September 30,1993 ), the depletion charge is $\$ 11.98$ per acre-foot for the average annual depletion which equals a total payment of $\$ 706.82$ for this project. This amount will be adjusted annually for inflation on October 1 of each year based on the previous year's Composite Consumer Price Index. The Service will notify the Department of Energy of any change in the depletion charge by September 1 of each year. The payment will be due at the time the construction commences. The amount payable will be adjusted annualiy for inflation on October 1 of each year based on the Composite Consumer Price Index. Fifty percent of the funds will be used for acquisition of water rights to meet the instream flow needs of the endangered fishes (unless otherwise recommended by the Implementation Committee); the balance will be used to support other recovery activities for the Colorado River endangered fishes. Payment should be made to the National Fish and Wildlife Foundation (Foundation).

National Fish and Wildlife Foundation
Suite 900
1120 Connecticut Avenue, N.W.
Washington, D.C. 20036

In a telephone conversation on August 13, 1993, Steve Hamp, Site Manager, verbally agreed to this payment.

Each payment is to be accompanied by a cover letter that identifies the project and biological opinion that requires the payment, the amount of payment enclosed, check number, and any special conditions identified in the biological opinion relative to disbursement or use of the funds (there are none in this instance). The cover letter also shall identify the name and address of the payor, the name and address of the Federal Agency responsible for authorizing the project, and the address of the Service office issuing the biological opinion. This information will be used by the Foundation to notify the payor, the lead Federal Agency, and the Service that payment has been received. The Foundation is to send notices of receipt to these entities within 5 working days of its receipt of payment.

In order to further define and clarify processes outlined in Sections 4.1.5, 4.1.6, and 5.3.4 of the Recovery Program, an additional agreement addressing Section 7 consultation on depletion impacts was developed. The Section 7 agreement establishes a framework for conducting all future Section 7 consultations on depletion impacts related to new projects and those associated with historic projects in the Upper Basin. Procedures outlined in the Section 7 agreement will be used in conjunction with the Plan to determine if sufficient progress is being accomplished in the recovery of the endangered fishes to enable the Recovery Program to serve as a reasonable and.prudent alternative to avoid jeopardy. The Plan is expected to be finalized in September 1993 and will be reviewed annually. 
In accordance with the agreement, the Service has agreed to assess impacts of projects that require Section 7 consultation and determine if progress toward recovery has been sufficient for the Recovery Program to serve as a reasonable and prudent alternative. If sufficient progress is being achieved, biological opinions will be written to identify activities and accomplishments of the

Recovery Program that support it as a reasonable and prudent alternative. If sufficient progress in the recovery of the endangered fishes has not been achieved by the Recovery Program, actions from the Plan will be identified which must be completed to avoid jeopardy to the endangered fishes. For historic projects, these actions will serve as the reasonable and prudent alternative as long as they are completed according to the schedule identified in the Plan. For new projects, these actions will serve as the reasonable and prudent alternative so long as they are completed before the impact of the project occurs. The Slick Rock project is considered a new project.

The evaluation by the Service to determine if sufficient progress has been achieved considered (a) actions which result in a measurable population response, a measurable improvement in habitat for the fishes, legal protection of flows needed for recovery, or a reduction in the threat of immediate extinction; (b) status of fish populations; (c) adequacy of flows; and (d) magnitude of the project impact. In addition, the Service considered support activities (funding, research, information and education, etc.) of the Recovery Program if they help achieve a measurable population response, a measurable improvement in habitat for the fishes, legal protection of flows needed for recovery, or a reduction in the threat of immediate extinction. The Service evaluated progress separately for the Colorado River and Green River subbasins; however, it gave due consideration to progress throughout the Upper Basin in evaluating progress toward recovery.

Based on current Recovery Program accomplishments (Appendix A) and the expectation that the Plan will be fully implemented in a timely manner, the Service determined that sufficient progress has been achieved under the Recovery Program so that it could serve as the reasonable and prudent alternative to avoid jeopardy to the endangered fishes by the impacts caused by this permit. For historic projects, the responsibility for implementation of all elements of the reasonable and prudent alternative rests with the Recovery Program participants, not the individual project proponent. For new projects the responsibility for implementation of elements of the reasonable and prudent alternative are shared by the Recovery Program and the applicant. Recovery Program participants are responsible for carrying out activities outlined in the Plan.

In the event that the Recovery Program is unable to implement the Plan in a timely manner, as long as the lead Federal Agency has discretionary authority over the project, reinitiation of Section 7 consultation may be required so that a new reasonable and prudent alternative can be developed by the Service.

\section{INCIDENTAL TAKE}

Section 9 of the Endangered Species Act, as amended, prohibits any taking (harass, harm, pursue, hunt, shoot, wound, kill, trap, capture or collect, or attempt to engage in any such conduct) of listed species without a special 
exemption. Harm is further defined to include significant habitat modification or degradation that results in death or injury to listed species by significantly impairing behavioral patterns such as breeding, feeding, or sheitering. Under the terms of Section $7(b)(4)$ and Section $7(0)(2)$, taking that is incidental to and not intended as part of the agency action is not considered taking within the bounds of the Endangered Species Act, provided that such taking is in compliance with the incidental take statement.

The Service does not anticipate that the proposed action will result in any incidental take of the endangered fishes.

\section{CONCLUSION}

This concludes the Service's biological opinion on the impacts of the proposed project. This opinion was based upon the information described herein. If new information becomes available, new species listed, or. should there be any changes in the total average annual amount of water depleted by this project (59 acre-feet per year) or any other project change which alters the operation of the project from that which is described in the biological assessment and which may affect any endangered or threatened species in a manner or to an extent not considered in this biological opinion (see 50 CFR 402.16), formal Section 7 consultation should be reinitiated.

Thank you for your cooperation in the formulation of this biological opinion and your interest in conserving endangered species.

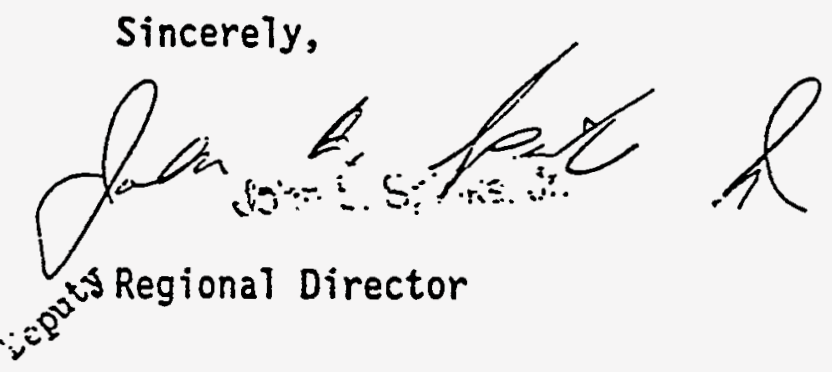




\section{REFERENCES}

Archer, D.L., H.M. Tyus, and L.R. Kaeding. 1986. Colorado River fishes monitoring project, final report. U.S. Fish and Wildlife Service, Colorado River Fishery Project, Lakewood. 64 pp.

Behnke, R.J., and D.E. Benson. 1983. Endangered and threatened fishes of the Upper Colorado River Basin. Ext. Serv. Bul1. 503A, Colorado State University, Fort Collins. $38 \mathrm{pp}$.

Bestgen, K.R. 1990. Status Review of the Razorback Sucker, Xyrauchen texanus. Larval Fish Laboratory \#44. Coiorado State University, Ft. Collins.

Carlson, C.A., and R.T. Muth. 1989. The Colorado River: Tifeline of the American Southwest. Pages 220-239 in D.P. Dodge, ed. Proceedings of the International Large River Symposium. Canadian Special Publication of Fisheries and Aquatic Sciences 106, Ottawa.

Ellis, N.M. 1914. Fishes of Colorado. University of Colorado Studies. Vol. $11(1)$.

Hamman, R.L. 1981. Spawning and culture of Colorado squawfish Ptychocheilus lucius in a raceway. In Miller et al. Colorado River Fishery Project Final Report.

Haynes, C.M., R.T. Muth, and T.P. Nesler. 1985. Identification of habitats and limiting factors for Colorado squawfish and humpback chub. Final Report, Federal Aid in Fish and Wildlife Restoration, Project SE-3-4. Colorado Division of Wildlife, Denver. 62 pp.

Holden, P.B., and C.B. Stalnaker. 1975. Distribution and abundance of mainstream fishes of the middle and upper Colorado River basins, 19671973. Transactions of the American Fisheries Society 104(2):217-231.

Jordan, D.S. 1891. Report of explorations in Colorado and Utah during the summer of 1889 with an account of the fishes found in each of the river basins examined. Butletin of the United States Fish Commission 9:24.

Joseph, T.W., J.A. Sinning, R.J. Behnke, and P.B. Holden. 1977. An evaluation of the status, life history, and habitat requirements of endangered and threatened fishes of the upper Colorado River system. U.S. Fish and Wildlife. Service, Office of Biological Services, Fort Collins, Colorado, FWS/OBS 24, Part 2:183.

Kaeding, L.R., and D.B. Osmundson. 1987. Studies of endangered Colorado River fishes: Conservation measures for the Green Mountain and Ruedi Reservoir water sales. U.S. Fish and Wildlife Service, Grand Junction, Colorado. $30 \mathrm{pp}$. 
Kidd, G. 1977. An investigation of endangered and threatened fish species in upper Colorado River as related to Bureau of Reclamation Projects. Final Report, Bureau of Reclamation, Salt Lake City, Utah. 36 pp.

Lanigan, S.H., and H.M. Tyus. 1989. Population size and status of the razorback sucker in the Green River basin, Utah and Colorado. North American Journal of Fisheries Management 9:1.

Marsh, P.C., and W.L. Minckley. 1989. Observations on recruitment and ecology of razorback sucker: lower Colorado River, Arizona-California. Great Basin Naturalist $49(1): 71-78$.

McAda, C.W. 1987. Status of the razorback sucker Xyrauchen texanus in the Colorado River upstream from Lake Powell. Proceedings of the Desert Fishes Council 17(1985):185.

McAda, C.H., and R.S. Hydoski. 1980. The razorback sucker, Xyrauchen. texanus, in the upper Colorado River basin, 1974-76. U.S. Fish and Wildlife Service Technical Paper 99.50 pp.

McCarthy, C.W., and W.L. Minckley. 1987. Age estimation for razorback sucker (Pisces: Catostomidae) from Lake Mohave, Arizona and Nevada. Journal Arizona-Nevada Academy of Science 21:87-97.

Milhous, R.T. 1982. Effect of sediment transport and flow regulation on the ecology of gravel-bed rivers. In Hey, R.D., J.C. Bathwist, and C.R. Thorne, eds. Gravel-bed rivers. John Wiley and Sons, New York.

Miller, W.H., D.L. Archer, J. Valentine, H.M. Tyus, R.A. Valdez, and L.R. Kaeding. 1982. Final Report: Colorado River Fishery Project. U.S. Fish and Wildlife Service and Bureau of Reclamation, Salt Lake City, Utah.

Miller, R.R. 1961. Man and the changing fish fauna of the American Southwest. Papers of the Michigan Academy of Science, Arts, and Letters $46: 365-404$.

Minckley, W.L. 1983. Status of the razorback sucker, Xyrauchen texanus (Abbott), in the lower Colorado River basin. Southwestern Naturalist 28:165-187.

O'Brien, J.S. 1984. 1983 Yampa River cobble reach morphology investigation. Final Report. U.S. Fish and Wildlife Service, Denver, Colorado. $79 \mathrm{pp}$.

Osmundson, D.B., and L.R. Kaeding. 1989. Studies of Colorado squawfish and razorback sucker use of the "15-mile reach" of the Upper Colorado River as part of conservation measures for the Green Mountain and Ruedi Reservoir water sales. Final Report. U.S. Fish and Wildlife Service, Grand Junction, Colorado. 
Osmundson, D.B., and L.R. Kaeding. 1991. Flow recommendations for maintenance and enhancement of rare fish habitat in the 15-mile reach during October-June. Final Report. U.S. Fish and Wildlife Service, Grand Junction, Colorado.

Platania, S.P. 1990. Biological summary of the 1987 to 1989 New Mexico-Utah ichthyofaunal study of the San Juan River. Unpublished report to the New Mexico Department of Game and Fish, Santa Fe, and the U.S. Bureau of Reclamation, Salt Lake City, Utah, Cooperative Agreement 7-FC-40-05060.

PTatania, S.P., and D.A. Young. 1989. A Survey of the Icthyofauna of the San Juan and Animas Rivers from Achuleta and Cedar Hill (respectively) to their Confluence at Farmington, New Mexico. Department of Biology, University of New Mexico, Albuquerque.

Seethaler, K. 1978. Life History and Ecology of the Colorado Squawfish (Ptychocheilus lucius) in the upper Colorado River basin. Thesis, Utah State University, Logan.

Tyus, H.M. 1987. Distribution, reproduction, and habitat use of the razorback sucker in the Green River, Utah, 1979-1986. Transactions of the American Fisheries Society 116:111-116.

Tyus, H.M., and C.A. Karp. 1989. Habitat Use and Streamflow Needs of Rare and Endangered Fishes, Yampa River, Colorado. U.S. Fish and Wildlife Service, Biology Report $89(14) .27$ pp.

Tyus, H.M., and C.A. Karp. 1990. Spawning and movements of razorback sucker, Xyrauchen texanus, in the Green River basin of Colorado and Utah. Southwestern Naturalist 35. (In Press)

Tyus, H.M., B.D. Burdick, R.A. Valdez, C.M. Haynes, T.A. Lytle, and C.R. Berry. 1982. Fishes of the Upper Colorado River Basin: Distribution, abundance and status. Pages 12-70 in Miller, H.H., H.M. Tyus and C.A. Carlson, eds. Fishes of the Upper Colorado River System: Present and Future. Western Division, American Fisheries Society, Bethesda, Maryland.

U.S. Fish and Wildlife Service. 1982. Colorado River Fishery Project Final Report. Part I (42 pp.), Part II (356 pp.), and Part III (342 pp.). Prepared for the U.S. Bureau of Reclamation, Salt Lake City, Utah. April 1982.

U.S. Fish and Wildlife Service. 1987. Recovery Implementation Program for Endangered Fish Species in the Upper Colorado River Basin. U.S. Fish and Wildlife Service, Denver, Colorado. $82 \mathrm{pp}$.

Valdez, R.A., P.G. Mangan, R.P. Smith, and B.C. Nilson. 1982. Upper Colorado River investigation (Rifle, Colorado to Lake Powell, Utah). U.S. Fish and Hildlife Service and Bureau of Reclamation, Final Report, Part 2, Colorado River Fishery Project, Salt Lake City, Utah. 
Valdez, R.A., and W.J. Mass7ich. 1989. Winter habitat study of endangered fish - Green River. Bureau of Reclamation, Salt Lake City, Utah. $178 \mathrm{pp}$.

Vanicek, C.D., and R.H. Kramer. 1969. Life history of the Colorado squawfish Ptychocheilus lucius and the Colorado chub Gila robusta in the Green River in Dinosaur National Monument, 1964-1966. Transactions of the American Fisheries Society $98(2): 193$. 


\section{APPENDIX A}

\section{ACTIVITIES AND ACCOMPLISHMENTS OF THE RECOVERY IMPLEMENTATION PROGRAM \\ RELATED TO SECTION 7 CONSULTATIONS \\ UPPER COLORADO RIVER BASIN \\ MAY 1993}

\section{Background}

The Fish and Wildlife Service (Service) will determine whether progress by the Recovery Implementation Program (Program) provides a reasonable and prudent alternative based on the following factors:

a. Actions which result in a measurable population response, a measurable improvement in habitat for the fishes, legal protection of flows needed for recovery, or a reduction in the threat of immediate. . extinction.

b. Status of fish populations.

c. Adequacy of flows.

d. Magnitude of the impact of projects.

The Service will assess the impacts of projects that require Section 7 consultations and determine if accomplishments under the Program are sufficient for it to serve as a reasonable and prudent alternative. Generally, sufficient progress will be evaluated separately for the colorado and Green River Subbasins, although due consideration will be given to progress throughout the Upper Colorado River Basin.

Colorado River Subbasin Accomplishments

1. Actions which result in a measurable population response, legal protection of flows, or a reduction in the threat of immediate extinction:

a. Execution of an agreement by the Bureau of Reclamation (Reclamation), Service, and Colorado Hater Conservation Board to provide a permanent commitment of 10,000 acre-feet of Ruedi Reservoir releases to and through the 15-mile reach.

b. Application to the water court by the Colorado Water Conservation Board to file for a $581 \mathrm{cfs}$ instream flow right for the 15-mile reach for the months of July, August, and September.

c. Estab7ishment of refugia for the Colorado squawfish and razorback sucker from the Colorado River. 
d. Agreement by Reclamation and the Colorado Water Conservation Board to provide an additional 10,000 acre-feet of water from Ruedi Reservoir on a year-to-year basis. The additional water has been/will be provided in 1991, 1992, and 1993. A longer term arrangement of water from the Ruedi Reservoir is being developed.

e. Reoperation of the Aspinall Unit to provide test flows and enhance endangered fish habitat conditions in the Gunnison and Colorado Rivers.

2. Adequacy of flows:

a. Winter--adequate; legal protection yet to be provided.

b. Spring--duration and magnitude of peak spring flows is less than adequate; legal protection yet to be provided.

c. Summer-Fall--generally adequate with shortages in the 15-mile reach; legal protection partially provided.

\section{Green River Subbasin Accomplishments}

1. Actions which result in a measurable population response, legal protection of flows, or a reduction in the threat of immediate extinction:

a. Commitment from Reclamation and Western Area Power Administration to reoperate the $F$ laming Gorge Project to enhance endangered fish habitat in the Green River pursuant to the biological opinion on the reoperation of the Flaming Gorge Project.

b. Partial establishment of refugia for razorback sucker from the Green and Yampa Rivers.

2. Adequacy of flows:

a. Service flow recommendations being implemented pursuant to Flaming Gorge biological opinion; legal protection yet to be provided.

b. Yampa River/Little Snake River--current flows adequate with some localized shortages in late summer and early fall; legal protection yet to be provided.

c. White River--current flows adequate; legal protection yet to be provided.

d. Duschesne--flow requirement unknown. 
Major Recovery Program Support Activities (Basinwide):

Support activities (funding, research, I and E, etc.) in the Program that contribute to sufficient progress to the extent they help achieve a measurable population response, a measurable improvement in habitat for the fishes, legal protection of flows needed for recovery, or a reduction in the threat of immediate extinction.

1. Signing of a cooperative agreement to implement the Recovery Program.

2. Resolutions supporting the Recovery Program made by water user groups in Utah, Colorado, Wyoming, and several major environmental groups.

3. Active participation by all cooperators in implementing the Recovery Program, including meeting all funding commitments and seeking funds from Congress necessary to implement the. program.

4. The expenditure of $\$ 15.9$ million from 1988 to 1993 to implement the Recovery Program work plans. These work plans have provided funding for numerous high priority recovery activities and studies related to the endangered Colorado River fishes.

5. Commitment by members of the Recovery Program to develop and implement in a timely manner the Recovery Implementation Program Recovery Action Plan, which will give priority consideration to implementing recovery actions which will result in significant protection and improvement of the endangered fish populations in their habitat. 
ATTACHMENT 2

FLOODPLAIN/WETLANDS

ASSESSMENT 


\section{TABLE OF CONTENTS}

$\underline{\text { Section }}$

Page

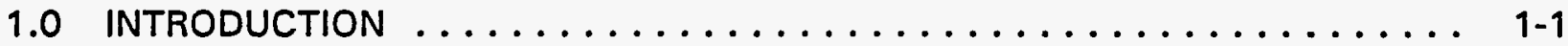

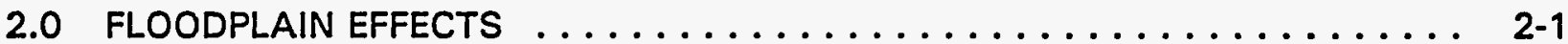

2.1 Existing floodplain conditions $\ldots \ldots \ldots \ldots \ldots \ldots \ldots \ldots \ldots \ldots, 2-1$

2.2 Floodplain disturbance during remedial action $\ldots \ldots \ldots \ldots \ldots \ldots, 2-1$

2.3 Post-remedial action activities $\ldots \ldots \ldots \ldots \ldots \ldots \ldots \ldots \ldots \ldots, 2-1$

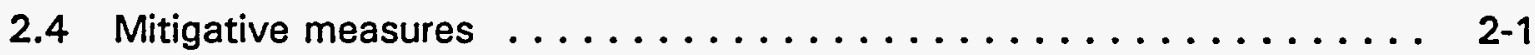

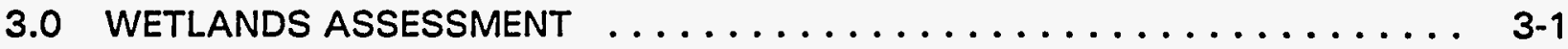

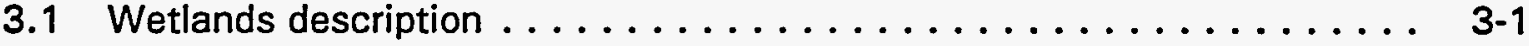

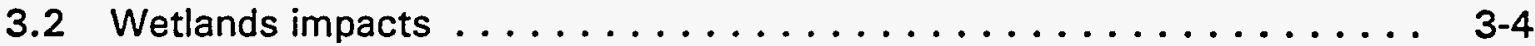

3.3 Mitigation of impacts on wetlands $\ldots \ldots \ldots \ldots \ldots \ldots \ldots \ldots$ 3-7

4.0 ALTERnATIVES TO THE PROPOSED ACTION $\ldots \ldots \ldots \ldots \ldots \ldots \ldots$ 4-1

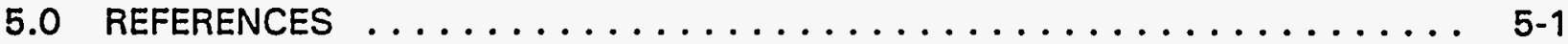




\section{LIST OF FIGURES}

Figure

Page

2.1 100-year floodplain boundary at the UC site, Slick Rock, Colorado . . . . . . 2-2

2.2100 -year floodplain boundary at the NC site, Slick Rock, Colorado . . . . . . . 2-3

3.1 Plant community types in the riparian zone along the Dolores River at the UC site, Slick Rock, Colorado . . . . . . . . . . . . . . . . . . 3-2

3.2 Plant community types in the riparian zone along the Dolores River at the NC site, Slick Rock, Colorado ....................... 3-3

\section{LIST OF TABLES}

Table

3.1 Nesting birds observed in 1990 and 1991 in the riparian zone along an $8-\mathrm{mi}(13-\mathrm{km})$ stretch of the Dolores River in the area of the Slick Rock, Colorado, UMTRA Project sites . . . . . . . . . . . . . . . . 


\section{LIST OF ACRONYMS AND ABBREVIATIONS}

$\begin{array}{ll}\text { Acronym } & \text { Definition } \\ \mathrm{ac} & \text { acre } \\ \mathrm{cm} & \text { centimeter } \\ \mathrm{DOE} & \text { U.S. Department of Energy } \\ \mathrm{EA} & \text { environmental assessment } \\ \mathrm{ft} & \text { feet } \\ \mathrm{ft}^{3} / \mathrm{s} & \text { cubic feet per second } \\ \mathrm{ha} & \text { hectare } \\ \mathrm{km} & \text { kilometer } \\ \mathrm{m} & \text { meter } \\ \mathrm{m}^{3} / \mathrm{s} & \text { cubic meters per second } \\ \mathrm{mi} & \text { mile } \\ \mathrm{MSL} & \text { mean sea level } \\ \mathrm{NC} & \text { North Continent } \\ \text { UC } & \text { Union Carbide } \\ \text { UMTRA } & \text { Uranium Mill Tailings Remedial Action }\end{array}$




\subsection{INTRODUCTION}

In 1979, the U.S. Department of Energy (DOE) established regulations (10 CFR Part 1022) to comply with floodplain/wetlands environmental review requirements. These regulations provide for compliance with Executive Order 11988, Floodplain Management, and Executive Order 11990, Protection of Wetlands. The regulations are designed to be coordinated with the environmental review requirements of the National Environmental Policy Act. This attachment assesses impacts on the floodplains and wetlands associated with the Slick Rock Uranium Mill Tailings Remedial Action (UMTRA) Project pursuant to 10 CFR Part 1022.

The two Slick Rock tailings piles, plus windblown and waterborne tailings, have contaminated lands within the floodplain of the Dolores River near the Union Carbide (UC) and North Continent (NC) tailings sites. The proposed action for the UC and NC sites is to move the two tailings piles and other contaminated materials to the Burro Canyon disposal site, which is an upland area 5.7 road miles (mi) $(9.2$ kilometers [km]) north of the NC site. More details regarding the proposed action are in Section 3.0 of the environmental assessment (EA). 


\subsection{FLOODPLAIN EFFECTS}

A flood analysis was performed to determine the impacts of remedial action in the 100-year floodplain. The estimated 100-year flood was determined using cloud-burst rainfall distributions (USACE, 1986) and 6-hour, 100-year precipitation values (Miller et al., 1973). This information was used in the HEC-1 computer program (USACE, 1981) to determine the peak discharges for the 100-year flood event. The HEC-2 computer model (USACE, 1982) was used to determine the boundary of the 100-year floodplain.

\section{$2.1 \quad$ EXISTING FLOODPLAIN CONDITIONS}

The boundaries of the 100-year floodplain of the Dolores River at the UC and NC sites are shown in Figures 2.1 and 2.2, respectively. A 100-year flow of 84,200 cubic feet per second $\left(\mathrm{ft}^{3} / \mathrm{s}\right)\left(2380\right.$ cubic meters per second $\left[\mathrm{m}^{3} / \mathrm{s}\right]$ ) could occur in the Dolores River near the UC and NC tailings sites. The bases of both tailings piles are within the 100-year floodplain. The maximum water level during the 100-year flood event would be 5446 feet (ft) (1660 meters [m]) above mean sea level (MSL) at the UC pile and $5465 \mathrm{ft}(1666 \mathrm{~m})$ above MSL at the NC site.

Borrow activities at the Dolores River borrow site would likely occur within the 100-year floodplain of the Dolores River. Analyses of the washes near the Disappointment Valley borrow site indicated that construction activities would not occur within the 100-year floodplain (Pioneer, 1979).

\subsection{FLOODPLAIN DISTURBANCE DURING REMEDIAL ACTION}

During remedial action, an estimated 28 acres (ac) (11 hectares [ha]) of land would be cleaned up in the floodplain of the Dolores River at the UC site; an estimated 13 ac ( $5 \mathrm{ha}$ ) would be cleaned up in the floodplain at the NC site. This cleanup would result in the excavation of up to $1 \mathrm{ft}(0.3 \mathrm{~m})$ of soil at these sites except at the tailings piles, where the excavation would be deeper. The net effect would be the clearing of all the vegetation and a slight deepening of the existing floodplain.

\subsection{POST-REMEDIAL ACTION ACTIVITIES}

To promote an increase in riparian habitat, the original contours of the Dolores River 100-year floodplain would not be reestablished after remedial action has been completed.

\subsection{MITIGATIVE MEASURES}

Potential impacts during remedial action within the floodplain of the Dolores River would be mitigated by use of the following measures:

- Contaminated materials in the floodplain would be excavated during periods of low flow in the river. 


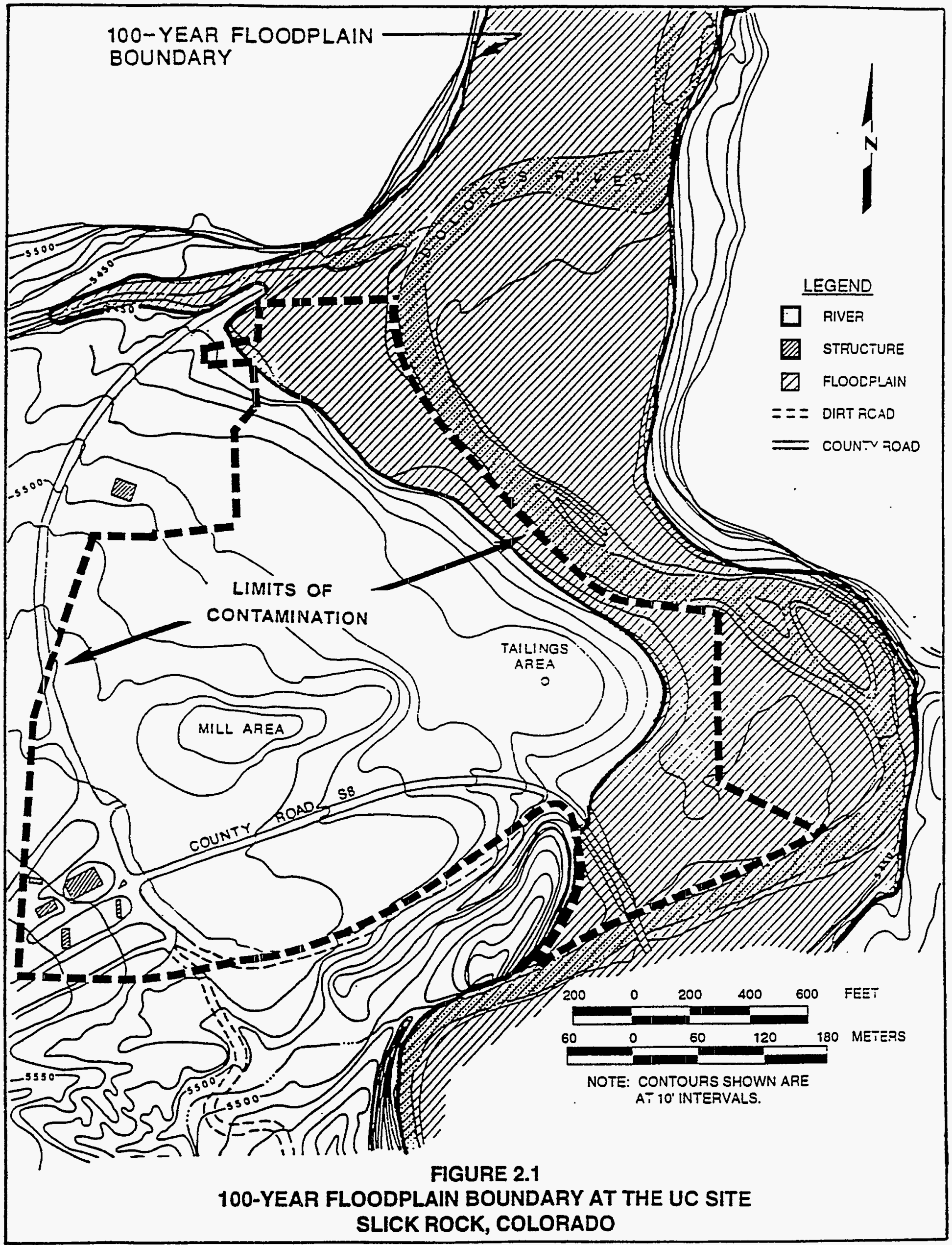




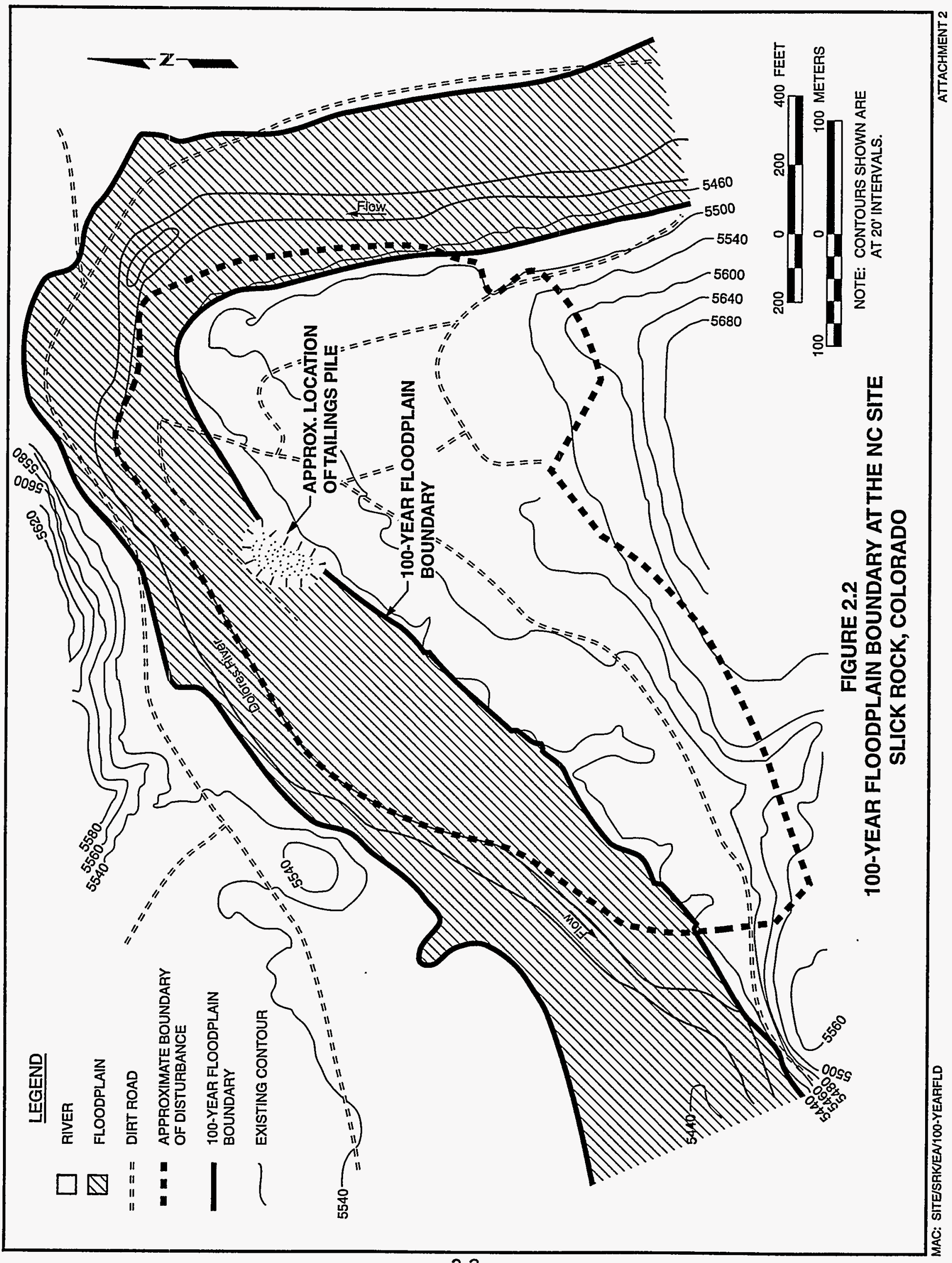


- Riparian vegetation along the river not subject to excavation would be left undisturbed as much as possible to reduce river velocities and associated erosion during flood events.

- Revegetation would begin as soon as practical after removal of contaminated materials.

- Berms, riprap, or other erosion controls would be used as necessary to minimize erosion.

- The excavated floodplain would be restored to preexisting conditions except for the UC pile. 


\subsection{WETLANDS ASSESSMENT}

\subsection{WETLANDS DESCRIPTION}

An estimated 21.3 ac (8.6 ha) of riparian plant communities are within the contaminated area next to the UC tailings pile, while $20.4 \mathrm{ac}(8.3 \mathrm{ha})$ of riparian plant communities occur near the NC tailings site (Figures 3.1 and 3.2). A third area of riparian plant communities contaminated with tailings is across the river from the UC site (Figure 3.1). This area covers 17 ac ( 7 ha) and would likely be excluded from remedial action because supplemental standards would be applied (MK Corporation, 1993). The area would be eligible for supplemental standards for the following reasons:

- The average radium-226 (Ra-226) levels are only slightly above the cleanup standard.

- Seventeen acres of scarce riparian habitat occur in this area.

- There is no vehicular or foot access to this area; there are no residences within $0.25 \mathrm{mi}(0.40 \mathrm{~km})$ of this site, and only 10 people live within $10 \mathrm{mi}$ $(16 \mathrm{~km})$ of the site.

- Remedial action would be very costly because it would be necessary to construct a bridge across the river to access the site.

- There is a low probability of health risks anticipated from radon emission, particulate inhalation, or ingestion of contaminated materials due to the Ra-226 concentration and remoteness of the area.

Four plant community types were observed in these three areas. The dense riparian shrub community grows in thin bands along the riverbank or on islands. Shrubs such as willow and saltcedar form a very dense growth in this habitat. Other shrubs observed included wild privet, fourwing saltbush, squawbush, Fendler rose, and big sagebrush. Small narrowleaf cottonwood and Russian olive were occasionally observed. There was little ground cover in the dense growth of willow and saltcedar; more open areas had a dense growth of grass and herbaceous species (e.g., yellow sweet clover and milkvetch).

The remaining riparian plant communities are at a somewhat higher elevation above the river. The upper riparian grass type had a dense ground cover of grass and herbs with widely scattered shrubs, including big sagebrush, rabbitbrush, wild privet, greasewood, saltbush, squawbush, Fendler rose, saltcedar, and Russian olive. The upper riparian shrub type was similar except that shrubs were much more common; sagebrush, rabbitbrush, and greasewood were most abundant. This type also had a dense ground cover of grass and herbs. 


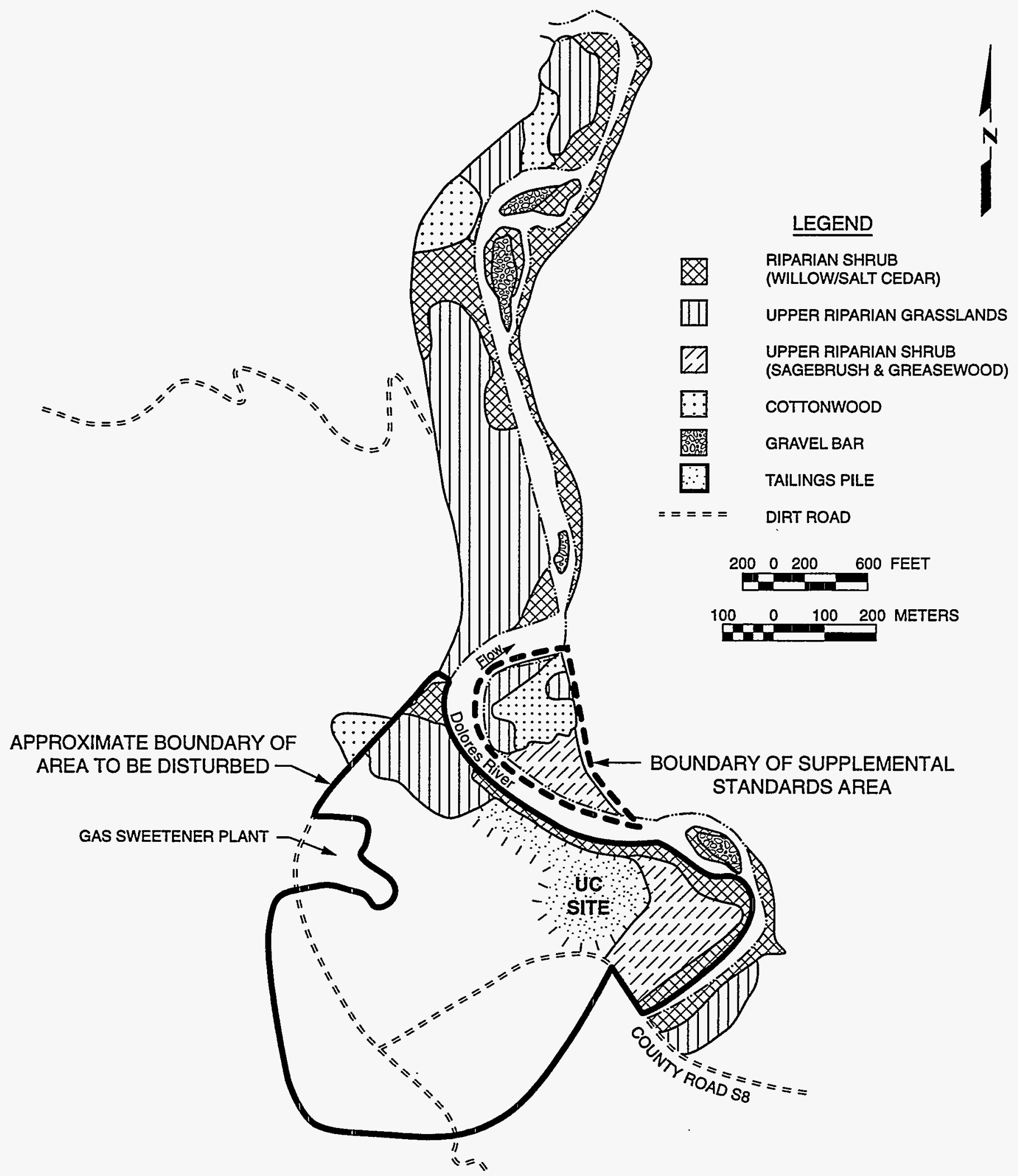

FIGURE 3.1

PLANT COMMUNITY TYPES IN THE RIPARIAN ZONE ALONG THE DOLORES RIVER AT THE UC SITE SLICK ROCK, COLORADO 





The final riparian plant community was dominated by cottonwood. Fremont cottonwood was the dominant species; some narrowleaf cottonwood was also observed. The cottonwood stands were open and most of the cottonwoods were fairly large. The average height of 14 trees in the riparian zone across the river from the UC site was $45 \mathrm{ft}(14 \mathrm{~m})$ (ranging from 35 to $60 \mathrm{ft}$ [11 to $18 \mathrm{~m}$ ]), while the average diameter at breast height was about 20 inches (in)

(51 centimeters [cm]) (ranging from 10 to 32 in [25 to $81 \mathrm{~cm}]$ ). No cottonwood reproduction was observed, and an estimated 34 percent of the trees were either dead or dying. The lack of reproduction could be the result of grazing or the lowered water table due to irrigation withdrawals upriver of the UC and NC sites. There was a dense grass ground cover in these stands, and scattered shrubs, including squawbush, wild privet, sagebrush, greasewood, rabbitbrush, and box elder, were observed.

The riparian habitat is more diverse and productive in terms of wildlife use than the surrounding upland habitats. For example, quantitative studies of breeding birds indicate that densities are 3 to 10 times higher in the riparian zone than in the desert-shrub habitat (Szaro and Jakle, 1985; Johnson and Carothers, 1982). Warren and Schwalbe (1985) determined that lizard density was highest in the riparian zone along the Colorado River and lowest in the desert-shrub habitat. Observations along the Dolores River confirmed this; of the 75 species of birds observed at the sites, 64 were from the riparian zone and 37 were observed in the upland area (refer Table 2.4 in Attachment 1, Biological Assessment). Surveys for the southwestern willow flycatcher took place along an 8-mi $(13-\mathrm{km})$ stretch of the Dolores River in 1990 and 1991, and all nesting birds were recorded (Table 3.1). The cliff swallow is the most common species recorded; this colonial species was concentrated in two areas and was infrequently observed elsewhere along the river. The yellow-breasted chat was the most common noncolonial nesting species and was very common in the dense growth of willow, wild privet, and other shrubs that grow along the river. Other common species in this habitat were the mourning dove, yellow warbler, and spotted sandpiper. Species such as the great-blue heron, turkey vulture, red-tailed hawk, and American kestrel are recorded but were not known to nest along the segment of river surveyed.

Observations at the Slick Rock sites also indicate that mule deer use of the riparian zone was higher than of the surrounding upland habitat (DOE, 1983). Beaver are very common along the river and provide den sites for the stateendangered river otter, which has recently been reintroduced into the river. Refer to Attachment 1.for more details on the river otter use of the Dolores River.

\section{$3.2 \quad$ WETLANDS IMPACTS}

A total of 58.7 ac $(23.8 \mathrm{ha})$ of riparian plant communities are contaminated at or near the UC and NC sites. Supplemental standards would be applied to a 17-ac (7-ha) area across from the UC site, resulting in 41.7 ac (16.9 ha) of riparian plant communities being impacted (see Figures 3.1 and 3.2 ). 
Table 3.1 Nesting birds observed in 1990 and 1991 in the riparian zone along an 8-mi $(13-\mathrm{km})$ stretch of the Dolores River in the area of the Slick Rock, Colorado, UMTRA Project sites

\begin{tabular}{|c|c|c|}
\hline Species & 1990 & 1991 \\
\hline Cliff swallow & 52 & 100 \\
\hline Yellow-breasted chat & 31 & 52 \\
\hline Mourning dove & 26 & 24 \\
\hline Violet green swallow & 23 & 0 \\
\hline Yellow warbler & 18 & 19 \\
\hline Spotted sandpiper & 10 & 16 \\
\hline Scrub jay & 9 & 1 \\
\hline Western wood pewee & 8 & 2 \\
\hline Blue grosbeak & 7 & 3 \\
\hline Brown-headed cowbird & 6 & 5 \\
\hline Northern oriole & 6 & 9 \\
\hline Western kingbird & 5 & 2 \\
\hline Cedar waxwing & 5 & 0 \\
\hline Black-headed grosbeak & 5 & 5 \\
\hline Killdeer & 5 & 4 \\
\hline Black-billed magpie & 4 & 6 \\
\hline House wren & 4 & 1 \\
\hline Great-blue heron & 3 & 5 \\
\hline Black-chinned hummingbird & 3 & 1 \\
\hline Lark sparrow & 3 & 5 \\
\hline Turkey vulture & 2 & 3 \\
\hline Red-tailed hawk & 2 & 0 \\
\hline Common nighthawk & 2 & 0 \\
\hline Common crow & 2 & 0 \\
\hline Raven & 2 & 0 \\
\hline Solitary vireo & 2 & 1 \\
\hline Warbling vireo & 2 & 2 \\
\hline Northern mockingbird & 2 & 0 \\
\hline Rufous-sided towhee & 2 & 4 \\
\hline Say's phoebe & 2 & 1 \\
\hline
\end{tabular}


Table 3.1 Nesting birds observed in 1990 and 1991 in the riparian zone along an 8-mi $(13-\mathrm{km})$ stretch of the Dolores River in the area of the Slick Rock, Colorado, UMTRA Project sites (Concluded)

\begin{tabular}{lcc}
\hline \multicolumn{1}{c}{ Species } & 1990 & 1991 \\
\hline Mallard & 1 & 0 \\
Band-tailed pigeon & 1 & 0 \\
Belted kingfisher & 1 & 0 \\
White-throated swift & 1 & 21 \\
Lewis woodpecker & 1 & 0 \\
Ash-throated flycatcher & 1 & 1 \\
Gray flycatcher & 1 & 0 \\
Horned lark & 1 & 0 \\
Barn swallow & 1 & 11 \\
Northern rough-winged swallow & 1 & 0 \\
Blue-gray gnatcatcher & 1 & 0 \\
American robin & 1 & 2 \\
American goldfinch & 1 & 4 \\
Northern flicker & 0 & 2 \\
House finch & 0 & 10 \\
Lesser goldfinch & 0 & 1 \\
Kestrel & 0 & 3 \\
\hline & 266 & 326 \\
\hline Total & & \\
\hline
\end{tabular}

Ref.: TAC, 1990, 1991. 
The riparian vegetation along the Dolores River is a mosaic of habitat types that differ from each other primarily due to different species and/or vertical configuration of the vegetation. At present, the major factors affecting the pattern of this mosaic appear to be elevation (relative to the Dolores River) and grazing. The upper riparian shrub type is the most abundant habitat within the contaminated area (25.2 ac [10.2 ha]), followed by the dense riparian shrub (10 ac [4 hal), and the upper riparian grassland (6.5 ac [2.6 ha]). Cottonwooddominated areas would not be impacted because supplemental standards would be applied.

In May 1994, a biologist from the U.S. Army Corp of Engineers (USACE) inspected the riparian plant communities along the Dolores River in the area of the sites. It was agreed that the riparian shrub plant community type is the only riparian plant community that is under the jurisdiction of the USACE (Nall, 1994).

The clearing of 41.7 ac (16.9 ha) of riparian wetland vegetation would constitute an unavoidable impact on vegetation and wildlife. The clearing of vegetation from the riparian zone would reduce wildlife use to essentially zero. The duration of this impact would depend on the level and success of restoration efforts undertaken. Remedial action would remove not only the vegetation but also some of the topsoil. This topsoil cannot be stockpiled because it is contaminated and must be incorporated into the disposal cell.

\subsection{MITIGATION OF IMPACTS ON WETLANDS}

Revegetation represents the major mitigation measure to be applied to the wetlands at the UC and NC sites. The revegetation plan for USACE-regulated wetlands (10 ac [4 ha] of riparian shrub) will be provided in the DOE's 404 permit application. In addition, the 404 permit will undergo a public review period; agencies such as the Fish and Wildlife Service (FWS) and U.S.

Environmental Protection Agency (EPA) may require that the 404 permit address the revegetation of all riparian areas, including those that are not jurisdictional wetlands. Also, the BLM has been consulted regarding the revegetation of riparian plant communities at the Slick Rock sites, and this revegetation would be formulated in consultation with the USACE and other interested parties that could include the FWS, EPA, and BLM.

The revegetation of the impacted areas back to shrub-dominated plant communities would likely take place on its own but can also be hastened. For example, work in the revegetation of riparian habitats with pole plantings has proven successful (Swenson and Mullins, 1985; York, 1985). Cottonwood and willow, which are the two major species growing in the shrub-dominated wetlands along the Dolores River, have been successfully established from pole plantings. If possible, cuttings from vegetation growing near the disturbed land should be obtained. Revegetation of these areas should also include planting wild privet and ground cover of sedges and grass. An important consideration in this revegetation plan would be to prevent saltcedar from becoming a dominant species, as it currently is in some of the potentially impacted areas. 


\subsection{ALTERNATIVES TO THE PROPOSED ACTION}

The no action alternative consists of taking no steps toward remedial action at the UC and NC sites. The tailings and other contaminated materials would remain in their present condition and would continue to be subject to dispersal by wind and water erosion and unauthorized removal by humans. The selection of this alternative would not be consistent with the intent of Congress in the Uranium Mill Tailings Radiation Control Act (UMTRCA) (PL 95-604) and would not result in compliance with the proposed EPA standards (52 FR 36000).

The feasibility of applying supplemental standards was assessed and, as indicated in Section 3.1, supplemental standards would be applied to a 17-ac (7-ha) segment of riparian vegetation across the Dolores River from the UC site. The application of supplemental standards to the remaining riparian zone would not be feasible due to relatively high levels of contamination. 


\subsection{REFERENCES}

DOE (U.S. Department of Energy), 1983. "Environmental Assessment of Remedial Actions on the Uranium Mill Tailings Near Slick Rock, Colorado," unpublished report, prepared by the U.S. Department of Energy, UMTRA Project Office, Albuquerque Operations Office, Albuquerque, New Mexico.

Johnson, R. R., and S. W. Carothers, 1982. "Riparian Habitat and Recreation: Interrelationships and Impacts in the Southwest and Rock Mountain Region," Eisenhower Consortium for Western Environmental Forestry Research, Bulletin 12, University of Arizona, Tucson, Arizona.

Miller et al. (J. F. Miller, R. Frederick, and R. Tracy), 1973. Precipitation Frequency Atlas of the Western United States, NOAA Atlas 2, prepared by the U.S. Department of Commerce, National Oceanic and Atmospheric Administration, for the U.S. Department of Agriculture, Soil Conservation Service, Engineering Division, Silver Spring, Maryland.

MK Corporation, 1993. "UMTRA Project-Slick Rock, Colorado Memorandum Report Floodplain Area Across the River from the UC Sites to be Excluded from Remedial Action," MK Corporation, San Francisco, California.

Nall, S., 1994. Biologist, U.S. Army Corps of Engineers, Grand Junction, Colorado, personal communication with Chuck Burt, Jacobs Engineering Group Inc., UPDCC File Location No. 11.2.8, Albuquerque, New Mexico, November 4, 1988.

Pioneer (Pioneer Uravan, Inc.), 1979. Environmental Report, San Miguel Mill Project, San Miguel County, Colorado, prepared by Dames and Moore, Denver, Colorado, for Pioneer Uravan, Inc., UPDCC File Location No. 11.19.3, Albuquerque, New Mexico.

Swenson, E. A., and C. L. Mullins, 1985. "Revegetating Riparian Trees in Southwestern Floodplains," in Riparian Ecosystems and Their Management: Reconciling Conflicting Use, U.S. Forest Service, Rocky Mountain Forest and Range Experiment Station, General Technical Report RM-120, Fort Collins, Colorado.

Szaro, R. C., and M. D. Jakle, 1985. "Avian Use of a Desert Riparian Island and its Adjacent Scrub Habitat," in The Condor, Vol. 87, pp. 511-519.

TAC (Technical Assistance Contractor), 1991. "Unpublished Field Notes, Slick Rock Uranium Mill Tailings Site," unpublished report prepared by the TAC, Albuquerque, New Mexico, for the U.S. Department of Energy, UMTRA Project Office, Albuquerque Operations Office, Albuquerque, New Mexico.

TAC (Technical Assistance Contractor), 1990. "Unpublished Field Notes, Slick Rock Uranium Mill Tailings Site," unpublished report prepared by the TAC, Albuquerque, New. Mexico, for the U.S. Department of Energy, UMTRA Project Office, Albuquerque Operations Office, Albuquerque, New Mexico.

and 
USACE (U.S. Army Corps of Engineers), 1986. Hydrology Section, Sacramento, California, personal communication to Karen Agagino, Jacobs Engineering Group Inc., Albuquerque, New Mexico, December 1986.

USACE (U.S. Army Corps of Engineers), 1982. HEC-2 Water Surface Profiles, User's Manual, U.S. Army Corps of Engineers, Hydrologic Engineering Center Computer Program 723-X6-L202A, Davis, California.

USACE (U.S. Army Corps of Engineers), 1981. HEC-2 Flood Hydrograph Package, User's Manual, U.S. Army Corps of Engineers, Hydrologic Engineering Center Computer Program 723-X6-L2010, Davis, California.

Warren, P. L., and C. R. Schwalbe, 1985. "Herpetofauna in Riparian Habitats Along the Colorado River in the Grand Canyon," in Riparian Ecosystems and Their Management: Reconciling Conflicting Use, U.S. Forest Service, Rocky Mountain Forest and Range Experiment Station, General Technical Report RM-120, Fort Collins, Colorado.

York, J. C., 1985. "Dormant Stub Planting Techniques," in Riparian Ecosystems and Their Management: Reconciling Conflicting Uses, U.S. Forest Service, Rocky Mountain Forest and Range Experiment Station, General Technical Report RM-120, Fort Collins, Colorado.

\section{CODE OF FEDERAL REGULATIONS}

10 CFR Part 1022, Compliance with Floodplain/Wetlands Environmental Review Requirements, U.S. Environmental Protection Agency (1994).

\section{EXECUTIVE ORDERS}

11988, Floodplain Management, May 1977.

11990, Protection of Wetlands, May 1977.

\section{FEDERAL REGISTER}

52 FR 36000, Standards for Remedial Actions at Inactive Uranium Processing Sites: Proposed Rule, September 24, 1987.

\section{PUBLIC LAW}

PL 95-604, Uranium Mill Tailings Radiation Control Act of 1978, 42 USC $\$ 7901$, November 8, 1978, 95th Congress of the United States of America, Washington, D.C. 